\title{
A SURVEY OF ETHNIC COMPOSITION, SOME SOCIAL INSTITUTIONS AND RECENT POLITICAL HISTORY OF AFGHANISTAN.
}

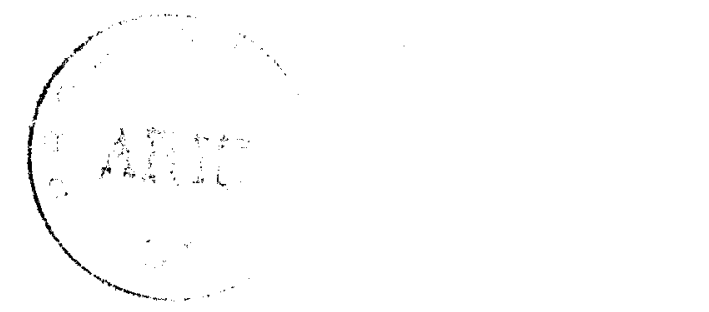

ISLAMABAD 2002 
LIST OF MAPS AND CHARTS.

INTRODUCTION.

CHAPTER ONE. THE GENERAL CHARACTERISTICS OF AFGHANISTAN AND ITS RELIGIOUS, LINGUISTIC, ETHNIC AND TRIBAL COMPOSITION.

1. Geography of Afghanistan.

1 .

1. Economy and the Life Cycle in the Afghan Society.

2 .

1. The Social structure of the Afghan Society.

3.

1. Major Languages of Afghanistan and Their Literary

4. Traditions.

1. Major Ethnic Groups.

5.

1.5. Iranian peoples.

1 .
1.5.1. Pashtuns.
1 .
1.5.1. Tajiks
2.
1.5.1. Persians
3.
1.5.1. Hazara.
4.
1.5.1. Char Aymaq
5.
1.5.1. Baluch.
6.
1.5.1. The Pamiris 7.

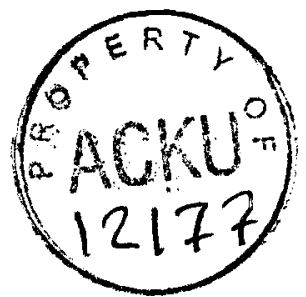

1.5. Turkic peoples.

2.

$$
\begin{aligned}
& \text { 1.5.2. Uzbeks } \\
& \text { 1. } \\
& \text { 1.5.2. } \\
& \text { 2. } \\
& \text { 1.5.2. } \\
& \text { 3. }
\end{aligned}
$$

1.5. Other peoples.

3.

$$
\begin{aligned}
& \text { 1.5.3. Nuristanis } \\
& 1 \text {. } \\
& \text { 1.5.3. The Dards } \\
& 2 . \\
& \text { 1.5.3. Brahui } \\
& \text { 1.5.3. Mongols } \\
& 4 . \\
& \text { 1.5.3. Arabs } \\
& 5 . \\
& \text { 1.5.3. Jews } \\
& 6 .
\end{aligned}
$$




\subsubsection{Sikhs and Hindus}

7.

1. Peculiarities of Afghan Islam. Sunnites, Shiites,

6. Ismailis and Sufis.

CHAPTER TWO. A RECENT POLITICAI HISTORY (1973-2001).

94-155

2.1 Afghan History Prior to the End of Monarchy.

2.2 The Republican Period.

2.3 The April 1978 Revolution and the End of the

. Mo-hammadzai Rule.

2.4 The Soviet Invasion and the Jihad.

$120-134$

2.5 The Mojcahed $n$ Rule.

134-142

2.6 The Taliban, al-Qלaé ${ }^{3} d a$ and the United Front.

$142-148$

2.7 The Fall of the Taliban.

2.8 Afghanistan and the UN.

148-149

2.9 Afghanistan and the Outside World.

149-152

2.1 The Humanitarian Situation.

$152-154$

0 .

$154-155$

APPENDICES.

- The Geneva Accords.

156-171

- Agreement on Provisional Arrangements in Afghanistan Pending the Re-establishment of Permanent Government Institutions (the Bonn Agreement).

171-174

- Key Players in Afghan Politics (Groups and Individuals).

175-175

THE CHRONOLOGY OF EVENTS.

176-178

RECOMMENDED READING.

BIBLIOGRAPHY.

180-191 


\section{NOTE ON TRANSLITERATION.}

\begin{tabular}{|c|c|c|c|c|c|c|}
\hline آ & $£ A$ & & $\square$ & $-D$ & $\dot{\varepsilon}$ & $\mathrm{GH}$ \\
\hline 1 & $\begin{array}{l}\text { A, I, E, U, } \\
\text { O, }\end{array}$ & $\delta$ & $\dot{~}$ & $\mathrm{DH}$ & ف & $\mathrm{F}$ \\
\hline ب & B & & J & $\mathrm{R}$ & ق & $\mathrm{Q}$ \\
\hline$Y$ & $\mathrm{P}$ & & $\square$ & $-\mathrm{R}$ & 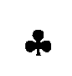 & $\mathrm{K}$ \\
\hline 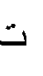 & $\mathrm{T}$ & & j & Z & $\mathfrak{R}$ & $\mathrm{G}$ \\
\hline$\alpha$ & $\ddot{Y} T$ & & $\square$ & $\ldots z$ & $U$ & $\mathrm{~L}$ \\
\hline$\dot{\Delta}$ & $\mathrm{TH}$ & & $\leq$ & $\ldots G$ & r & $\mathrm{M}$ \\
\hline ج & $\mathbf{J}$ & & س & $\mathrm{S}$ & $\dot{ن}$ & $\mathrm{~N}$ \\
\hline$\psi$ & $\ldots . C$ & & ش & $\ldots . . S$ & $\diamond$ & $\mathrm{N}$ \\
\hline$\square$ & $\mathrm{DZ}$ & & $f$ & $\ldots x$ & و & $\begin{array}{l}£ \\
O\end{array}$ \\
\hline$\square$ & TS & & ص & $-S$ & . & $\mathrm{H}$ \\
\hline$\tau$ & $-\mathrm{H}$ & & ض & ${ }^{\circ} \mathrm{z}$ & ى & $£ I$ \\
\hline- & $\mathrm{KH}$ & & $b$ & $-T$ & ى & $£ \mathrm{E}$ \\
\hline$\rho$ & $\mathrm{KH}^{\mathrm{w}}$ & & ظ & $-z$ & $ى$ & $\div Y$ \\
\hline د د & D & & $\varepsilon$ & $\hat{o}$ & s & $\delta \mathrm{Y}, \mathrm{A}$ \\
\hline
\end{tabular}

This system of transliteration is a simplified version of the transliteration used in Encyclopaedia Iranica and Persian Literature Series.

Special Pashto letters and sounds are shaded in the Note on Transliteration.

In Dari words the final short $a$, spelled $h$, is given as $a h$, in Pashto words the final $h$ is preceded by a vowel connoting an appropriate grammatical form.

The Dari izafah is given as -e, or -ye after a vowel. Izafah after $a h$ is given as -ye.

For transliteration of Arabic words, which were not borrowed by Dari or Pashto, the rules of Arabic transliteration, as specified in The Encyclopaedia of Islam, are applied. Thus, Uscama bin Lcadin, not Oscamah ben Lcaden.

The Arabic definite article is always given as al-, whether it precedes a "solar" or "lunar" consonant. For certain well-known places, ethnic names and terms popular Anglicised forms of spelling have been retained.

The plural of words in original languages is formed by adding an " $\mathrm{s}$ " to the singular, except in cases such as ôlamcaé, in which the transliterated plural form has become standard. For unwritten and dead languages International Iranian transcription is used. 
1. MAP 1.

2. MAP 2 .
AFGHAN PROVINCES IN 1978 (29 provinces).

AFGHAN PROVINCES IN 1992 (32 provinces). page

$\mathrm{V}$

\section{IIST OF CHARTS.}

1. Chart 1. Sedentary fofulation of AfGHAnistan.

page

KINSHIf-BASED TRIBAL STRUCTURE OF THE PASHTUN

2. CHART 2 . SOCIETY.

3. CHART 3.

IRANIAN AND INDO-ARYAN LANGUAGES OF AFGHANISTAN.

4. CHART 4.

QAYS AND HIS DESCENDANTS.

5. CHART 5.

THE SARBAN LINE ( 1 ).

6. CHART 6.

THE ...SARKHB $\zeta$ Un LINEAge $(1.1$.$) .$

7. CHART 7.

THE KHAR „SBCUN LINEAGE $(1.3$.

8. CHART 8.

The Batan/BETAN LIne (2).

9. CHART 9.

The Mateo lineage.

10. CHART 10.

THE GHILZAY COMMONWEALTH.

11. CHART 11.

THE ISM̨AÔ£IL LINEAGE (1.2.)

12. CHART 12.

THE GHURGU...ST LINE (3)

The KarRanI / KarLani COMmONWEALth.

THE KARRANI / KARLANI COMMONWEALTH.

THE KARRANI / KARLANI COMMONWEALTH.

15. CHART 13.3 .

16. CHART 14.

THE SULAYMEAN LINEAGE.

17. CHART 15.

THE DURRANI COMMONWEALTH.

18. CHART 16.

GEOGRAPHICAL, DEMOGRAPHIC AND LINGUISTIC DATA ON

19. CHART 17.

DARI-SPEAKING ETHNIC GROUPS.

20. CHART 18.

KINSHIP-BASED TRIBAI STRUCTURE OF THE HAZARA

21. CHART 19. SOCIETY.

22. CHART 20.

THE CHAR AYMAQ TRIBAL GROUPS.

23. CHART 21.

THE GROUP OF THE PAMIRI LANGUAGES.

ETHNIC COMPOSITION OF THE PAMIRI PEOPLES ACCORDING

24. CHART 22. TO THE SELF-IDENTIFICATION OF VARIOUS ETHNIC GROUPS 


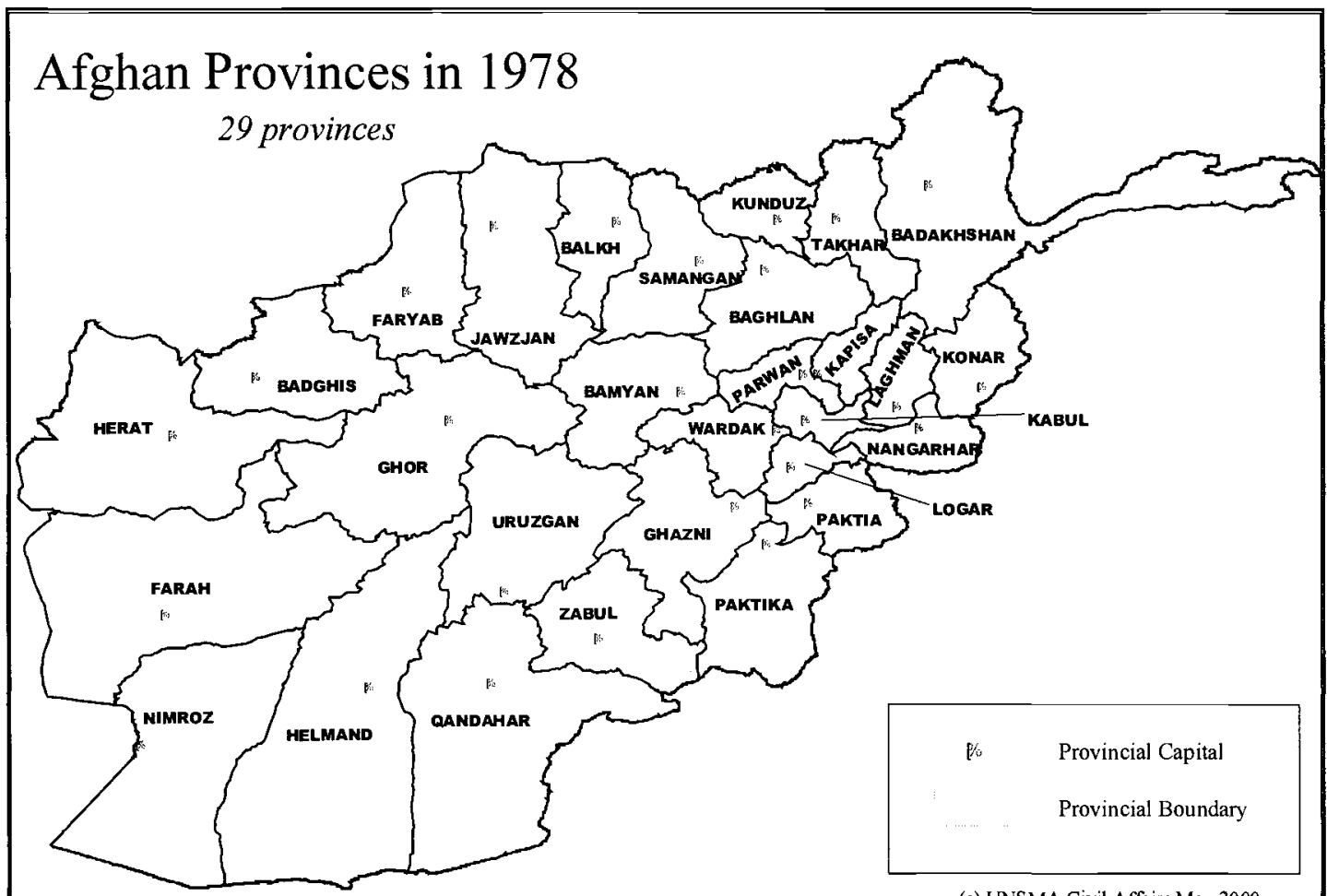

(c) UNSMA Civil Affairs May 2000

\section{Afghan Provinces in 1992}

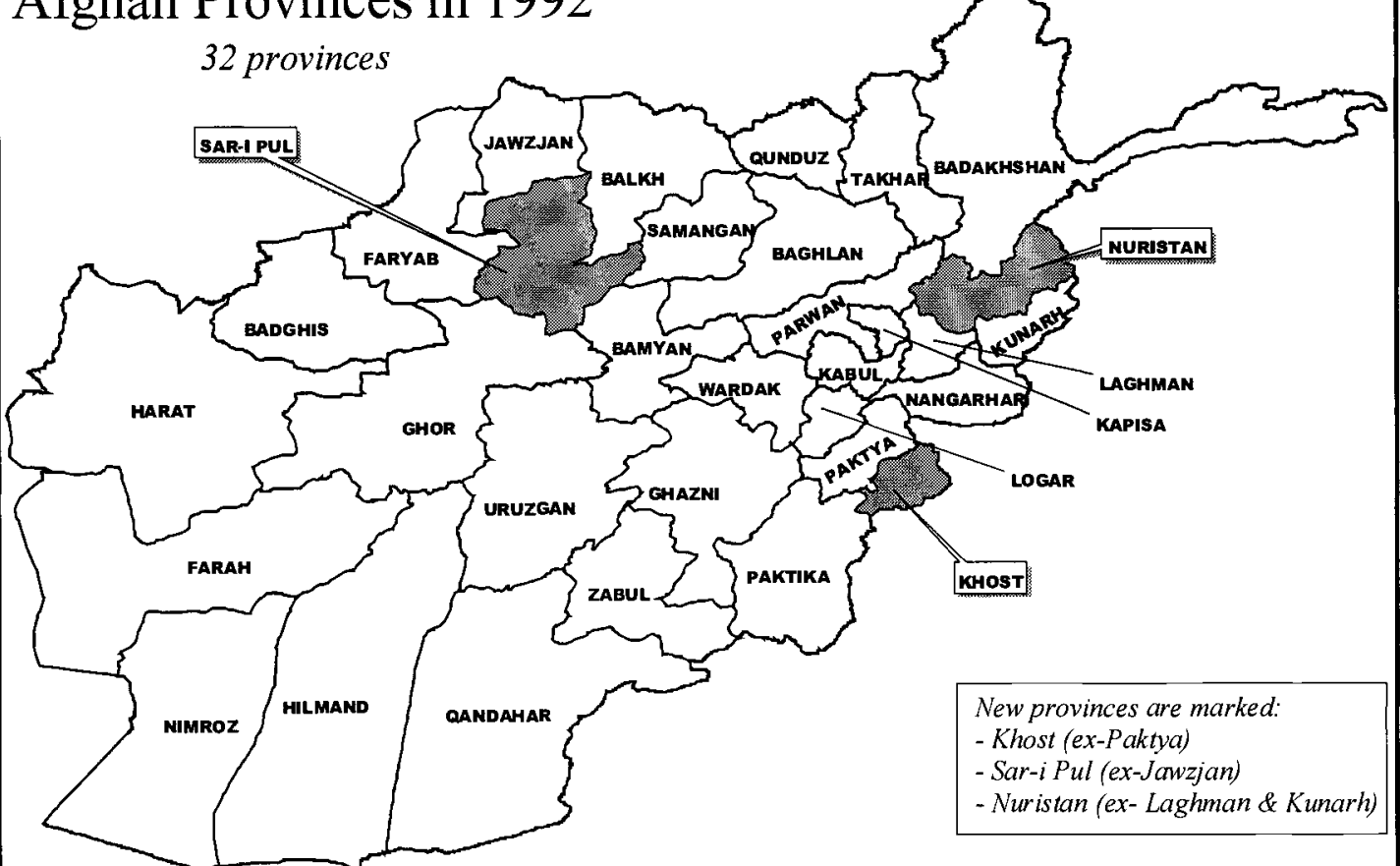

(c) UNSMA, Civil Affairs May 2000

Both maps are taken from "Administration in Afghanistan" prepared by UNSMA Civil Affairs Unit in May 2000. 


\section{INTRODUCTION.}

Any survey of Afghanistan should focus on socio-anthropological issues, since in Afghan society the rules of politics are defined by social realities, which are often not political in the traditional meaning of the word. The main characteristic of Afghan political life is that politics is first of all governed not by political organisations but by the institutions of a kinship-based tribal society and region-oriented ethnic groups. Thus tribes and ethnic groups act as one of the many political forces only when they interact with other political agents. However, the driving force behind outward tribal and ethnic policy is different from that behind the state or any other form of organised rule or religious coalition. Study of tribal and ethnic institutions traditionally has been considered as the domain of social anthropology. However, it seems impossible to understand Afghan history and politics using only historical tools. Since Afghan politics is very often a continuation of anthropology it is necessary to consider basic anthropological realities that shape political, social and economic behaviour of Afghans as a cornerstone of the historical and political study of Afghan society. Although this method was first used at the beginning of the $19^{\text {th }}$ century by the pioneer of Afghan studies Sir Mountstuart Elphinstone, later it was abandoned in favour of classical historical methodology'. Elphinstone's approach was partly

\footnotetext{
${ }^{1}$ Such prominent $19^{\text {th }}$ and $20^{\text {th }}$ century historians like W. Fraser-Tytler, Yu. Gankovskii, V. Gregorian, L. Poullada, I. Reisner, V. Romodin, P. Sykes considered Afghan history first of all as a development of state structures. Although they all mentioned the importance of a tribal factor they mainly failed to analyse the internal mechanisms of tribal life and their significance for the tribes' political positions. Modern scholars J.J.I. Gommans and A. Olesen who published their informative works in the 1990's also considered tribes only in their interaction with non-tribal political structures thus firmly remaining within the framework of the states-oriented tradition.
} 
revived by A. Snesarev and further developed by L. Dupree ${ }^{2}$ and O. Roy. Thus in order to understand Afghanistan one cannot limit himself to the discussion of political and military campaigns-centred history but also has to consider the realities of the every-day life which were usually the main force behind Afghans' political actions.

\footnotetext{
2 "It is not by chance that the greatest Western specialist on political life in Afghanistan for more than thirty years was an anthropologist, Louis Dupree, who analysed politics as if it were an extension of anthropology in other forms. One should see this approach not as a case of a specialist overstepping his bounds, but as a characteristic of political life in this country" (Roy, 1994, pp.222-223).
} 


\section{CHAPTER ONE. \\ THE GENERAL CHARACTERISTICS OF AFGHANISTAN AND ITS RELIGIOUS, LINGUISTIC, ETHNIC AND TRIBAL COMPOSITION.}

\subsection{GEOGRAPHY OF AFGHANISTAN.}

The area of Afghanistan is $650,000 \mathrm{sq} . \mathrm{km}$. The country is usually divided into 11 primary zones, which are basically either a part of the Hindu Kush mountain system or the peripheral plains and deserts. These primary zones are as follows:

1. The Wakhan corridor and the Pamirs knot,

2. Badakhshan,

3. Central mountains (the main axis of the Hindu-Kush),

4. Eastern mountains (Kabul, Kuhestan-Panjsher, Ghorband and Nuristan valley complexes),

5. Southern mountains and foothills,

6. Northern mountains and foothills (The band-e Turkestan, the Paropamisus, Kuh-e Changar and Firuzkuh ranges),

7. Turkestan plains,

8. Herat-Farah lowlands,

9. Helmand valley - Sistan basin,

10. Western stony deserts (Dasht-e Khash and Dasht-e Margo deserts)

11. South-western sandy deserts (Registan, Dasht-e Poghdar, Dast-e Arbu).

The bulk of Afghan regions are arid and semi-arid areas irrigated by three major river/drainage systems, namely

1. The north and nortwestward flow into the Central Asian depressions,

2. The west and southwestward flow, largely structurally controlled, into other basins, particularly the Sistan depression, 
3. The southeastward flow into the Indus system (Shroder, Jr, 1985, pp.486-491).

Lack of water is often a problem. As Louis Dupree puts it: "[the] problem is not insufficient water, for enough exists to increase productivity of current acreage... Control, not amount, is the difficulty. Most of the millions of acre-feet of water which seasonally pour down from the mountains disappears into the deserts, or is pirated away by the many uncoordinated irrigation intakes lining the rivers and tributaries" (Dupree, 1980, p.33). This multitude of irrigation intakes is integrated into the man made system of shafts connected by tunnels to intercept the water-table (the $k \operatorname{car}^{3} z$ system).

In Afghanistan geography reigns supreme; it often dictates political boundaries, determines military activities and social movements and limits ethnic expansion.

Many parts of Afghanistan fall into the category of what geographers and social anthropologists call a transition zone or shatter zone, or frontier ${ }^{3}$. It appears that all academic authorities agree on the following main characteristics of these zones: rugged terrain, which complicates movement within and through the zone; ecological and ethnic diversity; economic, social, political and administrative multistructuralism.

Several important arteries of trade ran through Afghanistan with the Khyber Pass being the most important gateway to the subcontinent.

Because of the heterogeneity and multistructuralism, which characterise Afghanistan the coherent consideration of the region's ethnographic, economic, social and even geographic patterns requires a more detailed analysis on the microregional level. The distinguishing characteristics of microregions offer an explanation of

\footnotetext{
3 The term "frontier" sometimes implies a peripheral area or buffer zone of geopolitical entities, civilizations or cultures. These frontiers may correspond to natural shatter zones and remain stationary over a considerable period of time. This is the case with Afghanistan, which has been a porous frontier (not strict boundary) between India, Iran and Central Asia for centuries.
} 
particular historical phenomena, which are often exclusively confined to these microregions. The microregions of the Pashtun lands are geographically distinct and therefore easily identifiable. Usually they are confined to the isolated river valleys. These microregions are unique in terms of their ecology, ethnic and/or tribal composition and economic activity. With the establishment of the organised rule in Afghanistan these microregions often began to coincide with the administrative units of the country.

Historically Afghanistan saw the gradual increase of the number of provinces (wel cayat) with the latest addition of three new provinces in 1992, i.e. Khost, Sar-e Pul and Nuristan, which were not clearly recognised by the successive governments. According to the 1964 Constitution the system of districts (wol $\div$ swcal ${ }^{3}$ ) and

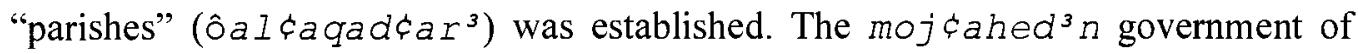
1992-1996 abolished the parish system with many ôl caqadłar ${ }^{3} s$ been granted the district status.

There has never been a proper census in Afghanistan and the population of the country is estimated as between 12 and 20 million people ${ }^{4}$.

\footnotetext{
${ }^{4}$ The situation is further complicated by the constant movement of refugees and internally displaced persons (IDPs).
} 
Chart 1. Sedentary population of Afghanistan ${ }^{*}$.

\begin{tabular}{|c|c|c|c|c|c|c|}
\hline REGTONS & PROVINCES & $\begin{array}{c}\text { RURAL } \\
\text { POPUIATION } \\
\text { IN THOUSANDS } \\
\end{array}$ & $\begin{array}{l}\text { URRAN } \\
\text { POPULATION } \\
\text { IN THOUSANDS } \\
\end{array}$ & $\begin{array}{c}\text { TOTAL } \\
\text { POPULATION } \\
\text { IN THOUSANDS } \\
\end{array}$ & \begin{tabular}{|l|} 
RURAI \\
POPULATION \\
IN PERCENT \\
\end{tabular} & $\begin{array}{c}\text { URBAN } \\
\text { POPULATION } \\
\text { IN PERCENT } \\
\end{array}$ \\
\hline \multirow{6}{*}{$\begin{array}{l}\text { CENTRAL } \\
\text { REGION }\end{array}$} & Kabul & 555.1 & $2,068.2$ & $2,623.3$ & 21.16 & 78.84 \\
\hline & Kapisa & 327.2 & 1.6 & 328.8 & 99.51 & 0.49 \\
\hline & Parwan & 631.0 & 32.4 & 663.4 & 95.12 & 4.88 \\
\hline & Wardak & 374.7 & 2.8 & 377.5 & 99.26 & 0.74 \\
\hline & Logar & 259.6 & 6.8 & 266.4 & 97.45 & 2.55 \\
\hline & REGION TOTAL & $2,147.6$ & $2,111.8$ & $4,259.4$ & 50.42 & 49.58 \\
\hline \multirow{5}{*}{$\begin{array}{l}\text { SOUTH- } \\
\text { EASTERN } \\
\text { REGION }\end{array}$} & Ghazni & 808.6 & 41.3 & 849.9 & 95.14 & 4.86 \\
\hline & Paktika & 319.9 & 1.9 & 321.8 & 99.41 & 0.59 \\
\hline & Paktia & 365.9 & 13.0 & 378.9 & 96.57 & 3.43 \\
\hline & Khost & 271.9 & 2.5 & 274.4 & 99.09 & 0.91 \\
\hline & REGION TOTAL & $1,766.3$ & 58.7 & $1,825.0$ & 96.78 & 3.22 \\
\hline \multirow{5}{*}{$\begin{array}{l}\text { EASTERN } \\
\text { REGION }\end{array}$} & Nangarhar & 904.9 & 86.1 & 991.0 & 91.31 & 8.69 \\
\hline & Konar & 290.8 & 2.8 & 293.6 & 99.05 & 0.95 \\
\hline & Laghman & 335.1 & 5.4 & 340.5 & 98.41 & 1.59 \\
\hline & Nuristan & 102.1 & - & 102.1 & 100.00 & - \\
\hline & REGION TOTAI & $1,632.9$ & 94.3 & $1,727.2$ & 94.54 & 5.46 \\
\hline \multirow{6}{*}{$\begin{array}{l}\text { NORTH- } \\
\text { EASTERN } \\
\text { REGION }\end{array}$} & Badakhshan & 639.8 & 13.8 & 653.6 & 97.89 & 2.11 \\
\hline & Takhar & 621.4 & 62.7 & 684.1 & 90.83 & 9.17 \\
\hline & Baghlan & 591.9 & 102.0 & 693.9 & 85.30 & 14.70 \\
\hline & Kunduz & 588.2 & 154.9 & 743.1 & 79.15 & 20.85 \\
\hline & Samangan & 270.8 & 6.7 & 277.5 & 97.59 & 2.41 \\
\hline & REGION TOTAL & $2,712.1$ & 340.1 & $3,052.2$ & 88.86 & 11.14 \\
\hline \multirow{5}{*}{$\begin{array}{c}\text { NORTHERN } \\
\text { REGION }\end{array}$} & $\mathrm{Balkh}$ & 629.6 & 222.8 & 852.4 & 73.86 & 26.14 \\
\hline & Jowzjan & 357.6 & 44.2 & 401.8 & 89.00 & 11.00 \\
\hline & Saripul & 395.1 & 31.8 & 426.9 & 92.55 & 7.45 \\
\hline & Faryab & 640.2 & 73.1 & 713.3 & 89.75 & 10.25 \\
\hline & REGION TOTAL & $2,022.5$ & 371.9 & $2,394.4$ & 84.47 & 15.53 \\
\hline \multirow{5}{*}{$\begin{array}{c}\text { WESTERN } \\
\text { REGION }\end{array}$} & Badghis & 267.9 & 7.3 & 275.2 & 97.35 & 2.65 \\
\hline & Herat & 820.9 & 252.4 & $1,073.3$ & 76.48 & 23.52 \\
\hline & Farah & 283.2 & 25.5 & 308.7 & 91.74 & 8.26 \\
\hline & Ghor & 439.6 & 4.1 & 443.7 & 99.08 & 0.92 \\
\hline & REGION TOTAL & $1,811.6$ & 289.3 & $2,100.9$ & 86.23 & 13.77 \\
\hline \multirow{7}{*}{$\begin{array}{c}\text { SOUTHERN } \\
\text { REGION }\end{array}$} & Nimruz & 127.5 & 8.8 & 136.3 & 93.54 & 6.46 \\
\hline & Helmand & 644.3 & 36.2 & 680.5 & 94.68 & 5.32 \\
\hline & Kandahar & 510.2 & 273.7 & 783.9 & 65.08 & 34.92 \\
\hline & Zabul & 227.6 & 8.0 & 235.6 & 96.60 & 3.40 \\
\hline & Oruzgan & 573.8 & 9.4 & 583.2 & 98.39 & 1.61 \\
\hline & REGION TOTAL & $2,083.4$ & 336.1 & $2,419.5$ & 86.11 & 13.89 \\
\hline & Bamiyan & 300.3 & 10.0 & 310.3 & 96.78 & 3.22 \\
\hline \multicolumn{2}{|c|}{ AFGHANISTAN TOTAL } & $14,476.7$ & $3,612.2$ & $|18,088.9|$ & 80.03 & 19.97 \\
\hline
\end{tabular}

*According to the 1996-1997 data of Central Statistical office of the Islamic State of Afghanistan. Estimated 1.5 million nomads are not included. Based on the table compiled by UNSMA CivAO Robert Kluijver. 


\subsection{ECONOMY AND THE LIFE-CYCLE IN THE AFGHAN SOCIETY ${ }^{5}$.}

There are two main types of the traditional economic activity in rural Afghanistan: agriculture and pastoralism. However, this distinction cannot be clearly defined since both tribes/ethnic groups and individuals are often simultaneously engaged in farming and herding. Therefore in most cases it is difficult to identify groups of people, or even individuals, as "nomads" or "agriculturalists". Among the Pashtuns most tribal groups include both nomads and settled, many families are engaged in both types of economic activity, many individuals are nomadic pastoralists one year and settled the next - depending on personal circumstances and climatic changes. Families often divide into two parts: one specialises in pastoralism and the other in farming. Pastoralists include groups, which live in tents all year and migrate as well as those who live in tents only part of a year. Among those who migrate there are groups which travel long distance (up to $500 \mathrm{~km}$ ) with the aid of camels and those who move short distances only, using donkeys to carry their tents (Tapper, 1974, pp.126-128, 133; Ferdinand, 1958, p.71).

For these reasons estimates of Afghanistan's nomadic population vary widely and rarely specify which kinds of nomads are included. According to modern estimates in the 1960s Afghanistan nomads constituted about 1/4 of the entire population (10-12 million), i.e. roughly 2.4/2.7 million people (FAO, 1965, p.23; Kennedy, 1967, p.22). Specific estimates of "full-nomads", i.e. people who live in tents with no agricultural occupation vary from 200,000 to 2,741,488 (Majruh, 1969, p.156; Poullada, 1962, p.35). According to Tapper, the former figure is more realistic for "full-nomads" while the number of "semi-nomads" exceeds the latter figure

\footnotetext{
${ }^{5}$ Given the lack of reliable information on urban and industrialised economy as well as international legal and illegal trade in Afghanistan this section is limited to the analysis of traditional economic activities focusing predominantly on the Pashtuns who are better researched than other ethnic groups.
} 
(Tapper, 1974, p.128). According to Humlum, nomads constitute less than a half of pastoralists and one sixth of the total agricultural population of Afghanistan. However, they own the bulk of the country's livestock and predominate in the supply of the ovine products (Humlum, 1959, p.264). Zaripov supplies different figures. Thus he thinks that at the turn of the century $2 / 3$ of the people of Afghanistan were "nomads". The absolute number of migrating pastoralists in Afghanistan hardly changed during these sixty years. At the same time the population of the country increased almost twofold. Zaripov thinks that this constant number and at the same time decreasing percentage of the nomads can be explained by their increasing sedentarization in the 20th century (Zaripov, 1989, p.108). However, the number of these settled nomads is statistically insignificant. It appears that this constant number of pastoralists indicates that Afghanistan's ecological system can sustain only a certain number of them (three million according to Zaripov). Thus, their number is regulated by natural forces ${ }^{7}$. However, there is also an opposite concept maintained by Bernt Glatzer who suggests that the number of nomads (as well as seasonal labour) fluctuates in accordance with the changing irrigation conditions. Thus, the problem of nomadism in Afghanistan, like it is the case with many other societies, poses more questions rather than offers answers.

\footnotetext{
${ }^{6}$ Among the Pashtuns this proportion should be much higher. Various authors provide different data on the percentage of the nomad Pashtuns in Afghanistan (with no clear definition of who are considered as "nomads"). Thus A.A. Poliak maintains that in the early 1960s 27\% of Pashtuns were nomads and 25-30\% were semi-nomads (Poliak, 1964, pp.33, 203,205 ) while Sh. Zaripov estimates that in the early 1980 s $59 \%$ of the Pashtuns were nomads; he does not include semi-nomads into his statistics (Zaripov, 1989, p.111). Even given the consequences of the war which forced mainly settled agricultural Pashtuns to emigrate to Pakistan this twofold increase of the percentage of the nomads over twenty years appears unlikely. Therefore, one of the above-mentioned anthropologists is wrong in his estimates. Alternatively they might have used different criteria in defining "nomads".

${ }^{7} \mathrm{Cf}$. "Pastoral nomadism is doomed to stagnation because its economy is extensive and allows no permanent solution to the problem of balance at the expense of intensification of production. ... the number of livestock per head amongst the Hsiung-nu, who in ancient times occupied the territory which now constitutes Mongolia, corresponds almost exactly with the number which was found amongst the Mongols in Autonomous Mongolia in 1918. ... although the population of Mongolia in the sixties was double what it was in 1918, the number of pastoralists in the steppe remained practically unchanged (Khazanov, 1984, p.71).
} 
Like in many other similar societies Pashtun migrant pastoralists hold pasturelands in common tribal possession while sheep belong to the individual families.

From time immemorial nomad Pashtun tribes and clans specialised in carrying goods from India to Central Asia and Persia via Afghanistan during their seasonal migrations. In the course of time some clans abandoned nomad pastoralism for the sake of caravan trade and carried goods as far as Bukhara and Persia and then back to India (Reisner, 1954, pp.69-70) ${ }^{8}$. They are known as tej $c a r$ (merchant) clans ${ }^{9} . \mathrm{A}$ number of factors contributed to the development of the Pashtuns' trading activities: lack of pastoral resources and dependency on artisan products as well as migration routes going through the areas with developed agricultural communities (Ferdinand, 1962, p.124; Ferdinand, 1969, p.138). These trading nomads, as well as the nontrading ones, are an integral part of a universal complex system of economic interdependence of settled agricultural and nomad pastoralist communities. Jos A.L. Gommans describes this coexistence of Afghan nomads and peasants as a "dual economy" based on both pastoral-nomadic and sedentary-agrarian production: “... by combining stockbreeding, raiding, trading and agrarian expansion, the Afghan riycasat was able to bridge the divide between the two [economies, both agrarian and nomadic]" (Gommans, 1995, p.7).

Nomads were not the only people who supplemented their income by caravan trade. Some settled people also travelled along the great trading routes from India to Central Asia and Persia with various goods.

\footnotetext{
${ }^{8}$ Like all other nomads Pashtuns are engaged in both direct exchange and trade with peasant and urban communities and mediation in the trade between various sedentary societies.

${ }^{9}$ In the British Indian literature these trading clans are described as "powindah" (pawandah). However, this word means "a grazer, a wanderer" not "a trader". Among the Pashtuns it is used as a synonym of other appellations of the nomads. The trading nomads call themselves $t i j \sqsupset r$ (Ferdinand, 1962, p.158).
} 
It is a well-established tradition to describe the Pashtuns as savage highwaymen who prey on passing caravans. Although many tribes really consider the goods of travelling merchants as their legitimate booty ${ }^{10}$ their contribution to the interregional and even international trade is often overlooked.

Among both nomadic and agricultural Pashtun tribes the usage of land is regulated by the rules of periodical redistribution of plots (wce "s). By the end of the $19^{\text {th }}$ century when the most of the British Indian accounts of wce $s$ were written this custom was already considered an anachronism and was practised only by some tribes. Nevertheless, the practice of whe "s vividly illustrates the pattern of tribal economy and social life for its implications are far-reaching even nowadays as far as the status of various clans and individual families is concerned.

There are many variations in local implementations of wce $s$. Since analysis of all these local peculiarities is beyond the scope of the present work I shall provide a generalised account of this custom, which will describe the main traits of whe "s. Thus all full and equal members of a Pashtun tribe have the right to hold parcels of tribal land on a rotating basis. The land of the tribe is divided into regions corresponding to the number of clans. Every clan is allotted one of these regions. Then the land of the clan is subdivided into smaller plots corresponding to the number of the branches in this clan. Thus the division of tribal land corresponds to the patterns of segmentation within tribal lineages. But plots of land are not equal in terms of fertility. Therefore, in order to secure equal access to tribal assets land should be periodically reallotted. Thus branches of every clan alternate in their occupation of their clan's land and clans alternate in their occupation of tribal land. In this system individuals do not hold land as private property; they hold shares in the total land

\footnotetext{
${ }^{10}$ Usually only non-Pashtun traders are robbed. Since attacks on a travelling group of the tej car Pashtuns can trigger inter-tribal confrontation they are generally avoided.
} 
assets of their branch, the branch owns a share of the land of the clan, and the clan owns a share in the land of the tribe. All these shares are periodically reallotted. These reallotments involve a periodical wholesale migration of landowning "shareholders". To cope with the complications caused by this migration Pashtuns devised an elaborate system of property rights to houses and fruit-trees. Within the tribal branch every family is given a parcel of land. Land may be apportioned either to all family members regardless of their sex $\left(k h k_{\left.u l a h-w \xi e_{\#} s\right)}\right.$ or to men only (bandwhe"s). This practise varies in different tribes. Sometimes these family plots are reallocated on an annual basis. The land of Muslim scholars living with a particular

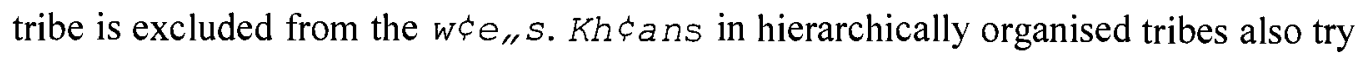
to exclude their plots from periodical reallotment (Bannu Gazetteer, 1883-1884, pp.213-229; Barth, 1965, pp.9-10, 65-67; Gordon, 1950, pp.50-52; Gordon, 1953, pp.46, 48-49; Raverty, 1888, p.207; Reisner, 1954, pp.104-132).

Work on land is considered necessary only for meeting immediate needs and is avoided when possible. No reserves beyond those securing physical survival are made (Rzehak and Griunberg, 1992, pp.195-196).

Alongside the whe $s$, patron-client relationship is one of the most important features of Pashtun socio-economic life. Hamscayah (one who shares shade), $f a q^{3} r$ (pauper) or $\operatorname{kam}^{3} n$ (defective, humble, junior) ${ }^{11}$ is the client of the patron (nłayek - literally "master", "owner"). By the force of social convention and because of considerations of personal and economic security Hindus, menials, artisans and people of little influence, both Pashtun and non-Pashtun, are compelled to place themselves under the protection of a powerful patron.

A hams cayah in return for protection is bound to support his patron and to assist him, even in the prosecution of his family feuds. Hindus never participate in

\footnotetext{
${ }^{11}$ In Punjab communal servants and artisans of the "untouchable" caste are called $\operatorname{kam}^{3} n$.
} 
actual fighting but supply their patrons with money and ammunition. Among the Orakzay Pashtuns the relationship of patron and client is established by giving a gift (I C $_{\text {" } x a y)}$ of a sheep to the prospective patron, Hindus also donate a cash present $^{12}$. Not only individuals but also whole clans of both Pashtun and non-Pashtun origin can become clients (White King, 1984, pp.21, 102-103). In that case these collective hamşayahs own their allegiance not to individuals but clans or whole tribes. Usually tribal $k h \xi a n s$ are responsible for administering these collective clients.

Among the Mohmands the duties of an individual hams cayah are as follows: he acts as a helper (khedmatgar), serves the guests of his patron, helps in the harvest and building work, fights for his patron. Therefore he is visible as a sign of his patron's power and prestige. He is required to keep the land tended, to pay a land tax in cash or kind to the khcan of the district at the collection of each harvest as well as a tax on the occasion of a marriage within his family ${ }^{13}$ (Ahmed, 1980; p.174; Bellew, 1864, pp.181-182; Peshawar Gazetteer, 1897-8, p.153). Legally hamscayahs have an inferior status. Their patrons are held responsible for their wrongdoings. All offences against clients are considered as an infringement of their patrons' honour. The "price of blood" of a hams cayah constitutes only one quarter of the "price of blood" of a free Pashtun. All clients are considered equal to each other. Usually debt-free hams cayahs have the right to leave their patron (Reisner, 1954, pp.198-200).

\footnotetext{
${ }^{12}$ It is difficult to agree with L. White King's suggestion that this custom is called 1 co "xay (dish, jar) because "... it is said that originally when a Hindu wished to become any one's hamsaya he sent him a jar of ghi as a declaration of such intention" (White King, 1984, p.103). It is more likely that this term denotes the symbolic exchange of food as a token of dependency.

${ }^{13}$ This obligation relates only to the hams cayah of a non-Pashtun origin. Pashtun clients had responsibilities only towards their direct patrons (Reisner, 1954, p.200).
} 
Historically the class of hams cayahs was composed of different groups of people. The minority of the clients descend from the dependent clans and communal servants who accompanied nomad Pashtun tribes during their migrations ${ }^{14}$. The majority of the hamsłayahs are indigenous agricultural people conquered and subdued by the Pashtuns. They are allowed to use their former land, which had become the property of a victorious Pashtun tribe. Among some Pashtun tribes a considerable number of their clients are migrants from India who came to the Pashtun lands and applied for the patronage of the Pashtuns. People of Pashtun origin who lost their land also become hams cayahs (Bellew, 1864, p.200; Reisner, 1954, pp.57-58, 196; Ridgway, 1910, p.180; Tupper, 1881, vol.II, p.16). These people also lose their right to be called Pashtuns. This loss entails deprivation of all civil rights (Rose, 1914, vol.III, p.206).

Different types of individual and collective clients are described by the term "hamscayah". They are as follows: tribal groups of nomadic merchants; tribes acting as junior military allies; free Pashtuns who left their own tribes and found the protection of a foreign tribe; Pashtuns enjoying protection of powerful fellow tribesmen; dependent people, usually non-Pashtuns, holding tribal land ${ }^{15}$. The latter category of clients is often called raôyat-e hams cayah (subject clients) if they

\footnotetext{
${ }^{14}$ Unlike their patrons hams cayahs of the nomad tribes are semi-nomads responsible for the cultivation of small parcels of land under crops (MacGregor, 1871, pp.239-240).

15 - Haykat-e Afghcan provides the following description of the hams Wazir tribe: "In every Wazir village are found, besides the subject-dependents or denizens (raôiyat-hamsaya) a number of others of Wazir blood who, after committing an offence or suffering an injustice among their own people, have fled to refuge to another village or clan. A fugitive, on coming to claim shelter and protection, slaughters a sheep, invites the maliks and headmen to the feast, and relating to them the circumstances that force him to seek refuge, declares himself their dependent or client (hamsaya). Those who have partaken of his feast, collectively and individually consider him as their client and make his cause their own. Another kind of client is the man who, unable to obtain payment of a debt due to him, or satisfaction of a right claimed in accordance with Wazir usage, constitutes himself, in the way just described, the client of some powerful person or clan, by whose means he obtains his desire upon his adversary" (Muhammad Hayat Khan, 1981, p.243).
} 
pay rent for the land they cultivate, or mlcata-r (helpers) if they provide military service in exchange for the right to use the land.

There are two types of the raôyat-e hams cayah: tribal and individual. Tribal hamsłayahs receive land from the patron tribe or clan. This tribe acts as a collective patron of client individuals or groups; and every tribesman receives a share of rent in accordance with the size of his own plot of land. Tribal hams cayahs usually do not blend with the Pashtuns and live in separate villages or hamlets. An individual hams cayah lives on the land of his patron. Not only the land he cultivates but also the client's house is considered as the patron's property. In the majority of Pashtun tribes both tribal and individual hams cayahs have the right to change their patrons (Reisner, 1954, pp.202-203).

Various tribes have different numbers of hamsłayahs. Usually tribes occupying fertile valleys suitable for agriculture have more hamscayahs while Pashtuns living high in the mountains, e.g. the Wazirs, Afridis, mountain Mohmands, have very few clients. Thus these Pashtuns cultivate their fields themselves. Among the valley tribes the hams cayahs often outnumber the tribesmen. Therefore cultivation of land is primarily their responsibility, although the Pashtuns do not hesitate to participate in agricultural work when their labour is needed (Elphinstone, 1839, vol.II, pp.27-29, 109; Reisner, 1954, pp.196-197; Ridgway, 1910, p.72).

The type of irrigation also affects the position of hamscayahs. In the territories with artificial irrigation and sufficient water and land resources (e.g. Daman) the hams cayah peasants who irrigated or cleared unused land from the jungle may hold these plots in their hereditary possession for a nominal payment to their patrons (Tupper, 1881, vol.II, pp.18, 22; vol.III, pp.108-109). In the territories with artificial irrigation and limited water resources (e.g. Bannu) clients are 
responsible for collective works concerning construction of the dams and maintaining the canals which belong to the patron tribe ${ }^{16}$ (Bannu Gazetteer, 1883-4, p.119; Tupper, 1881, vol.III, p.175). In these territories there are three types of relationships between the Pashtun owners of water and the hams cayah users of water: the client does irrigation work in exchange for the amount of water he receives as well as half of the patron's share of the communal irrigation work; apart from the above-mentioned work the client pays the patron rent in cash or kind; the third type resembles the association established between the patron and his military client, i.e. the client does not work for his patron and does not pay him any rent but serves him as a soldier in time of need (Bannu Gazetteer, 1883-4, pp.105, 109).

Unlike the peasant râyat-e hamsłayah, military clients (mI łata-r) do not pay for the use of tribal land but in return provide military service to the patron tribe. Like the raôyats the mlłata-r hamsłayahs live in separate villages $(b \nmid a n \ddot{Y} d a h)^{17}$. However, unlike the villages of the raôyat-e hamsłayah, their settlements are usually situated on the boundaries of the tribal lands and serve as shields against enemy attacks. Sometimes poor Pashtuns also live in these frontier błan ̈̇dahs (Peshawar Gazetteer, 1897-8, p.153).

Every tribe employs a number of artisans and menials who are not members of this tribe. The majority of them are paid in kind at harvest time. However, a few categories of these communal servants receive parcels of tribal land, which they can inherit. This practice as well as the allotted land is called kannah or "Cakeranah; it is an exact imitation of an Indian custom which was brought to the Pashtun lands by Indian members of artisan castes. Allotment of kannah or

\footnotetext{
${ }^{16}$ Small wells and canals may belong to individual owners.

${ }^{17}$ Initially the term " $b \nmid a n \ddot{Y} d a h$ " meant "shepherd's shed on summer pastures". Only later it was applied to the settlements of the hams cayah (Romodin, 1951[2], p.109).
} 
"cakeranah lands is practised only among Pashtun tribes that employ Indian artisans, in other tribes it is unknown (Muhammad Hayat Khan, 1981, p.68; Reisner, 1954, pp.205-209).

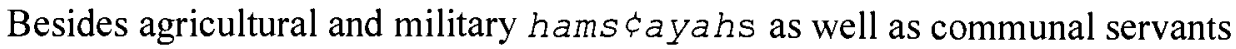
the Pashtuns traditionally had slaves; what is the modern situation is not quite clear. As it is also the case with the hams cayahs there are two types of slaves: slaveworkers and slave-warriors. Slave-warriors serve as personal troopers of khcans; like the mI cata-r hamscayahs they sometimes receive land for their service (Bellew, 1864, p.184; Reisner, 1954, p.190). From the economic point of view slaveworkers closely resemble raôyat-e hams çayahs but unlike the latter they do not enjoy personal freedom (Romodin, 1951[1], p.246). Impoverished raôyat-e hams cayahs who use their patrons' tools, cattle and seeds for the cultivation of land lose their personal freedom and turn into slave-debtors known as "çarek ar $^{3}$, i.e. those who work for one quarter of the harvest (Romodin, 1951[1], pp.312-314). Only non-Pashtun hamsłayahs can become chłarekłar ${ }^{3}$ s (Muhammad Hayat Khan, 1981, p.68).

The country of the Pashtuns, and especially its southern part, is a low production zone, which can hardly sustain its inhabitants; therefore, before the adoption of some elements of modern agriculture many of them had no choice but to rely on brigandry as an important source of their income. Alternatively, they often invaded more hospitable India and settled there, either establishing their own dynasties or joining the service of powerful empires ${ }^{18}$.

\footnotetext{
${ }^{18}$ This migration went both ways. Not only Pashtuns migrated to India but Indian peasants and artisans exhausted by economic hardships also moved to the country of the Pashtuns where they became the clients of local tribes.
} 
In the pre-industrial Pashtun society military activity is a part of the annual life-cycle. In long idle winter months when there is no agricultural or pastoral activity members of isolated Pashtun communities lapse into small-scale inter-family and inter-clan violence. Traditionally, feuds involve zan (women), zar (gold, symbolising portable property) and $z a m^{3} n$ (land, symbolizing immovable property including water rights). Louis Dupree suggests that this is the only acceptable way for Pashtun society to express the angst of in-group aggression and sexual competition caused by kinship restrictions on marriage as well as the adult male to female ratio of 116 to $100^{19}$. Thus potential in-group violence over property rights and female preference is channelled towards out-group elements, usually neighbouring Pashtun tribes or clans. Non-Pashtuns are never attacked during these small-scale "wars". Pashtuns never fight to ultimately defeat their enemy. The social convention has it that both sides must "win" which accounts for the insistence on an approximate equality of blood spilled and property looted. Real victories and defeats occur only when larger tribal units or non-Pashtun groups are involved. Low-scale conflicts and blood feuds resulting from them stop only for a major crisis caused by foreign invasions (Dupree, 1984, pp.266-286).

\subsection{THE SOCIAL STRUCTURE OF THE AFGHAN SOCIETY20.}

The basic unit at the bottom of the tribal structure is the household ( $k \notin \circ r)$. A number of households united by common descent constitute a clan ( $k h \xi e l)$. Every village consists of one or more clans. These localised $k h \xi e l s$ group into more inclusive

\footnotetext{
${ }^{19}$ This proportion is due to the preference for boys in Pashtun society, which leads to female infanticide, mainly through neglect. Besides, women are even less available than the figures may indicate since widows rarely remarry.

These customs may be considered as a primitive birth control, which is necessary in a low production pre-industrial society.

${ }^{20}$ Since the Pashtuns are the only Afghan ethnic group, which attracted considerable attention of social anthropologists this section inevitably focuses on this most numerous ethnic group.
} 
clans, identified by a common ancestor. These larger clans are not terminologically distinguished from the local $k h \xi e l s$. All patrilineal descendants of a particular forefather make up a tribe (qabelah or tcaefah). However, this trinomial distinction cannot be always applied to the realities of tribal organisation. It should be considered only as a general matrix, which shapes various local deviations. Tribesmen themselves often use the term qawm (literally "tribe") for the description of all levels of inclusion above the 
Chart 2. Kinship-based tribal structure of the Pashtun society.

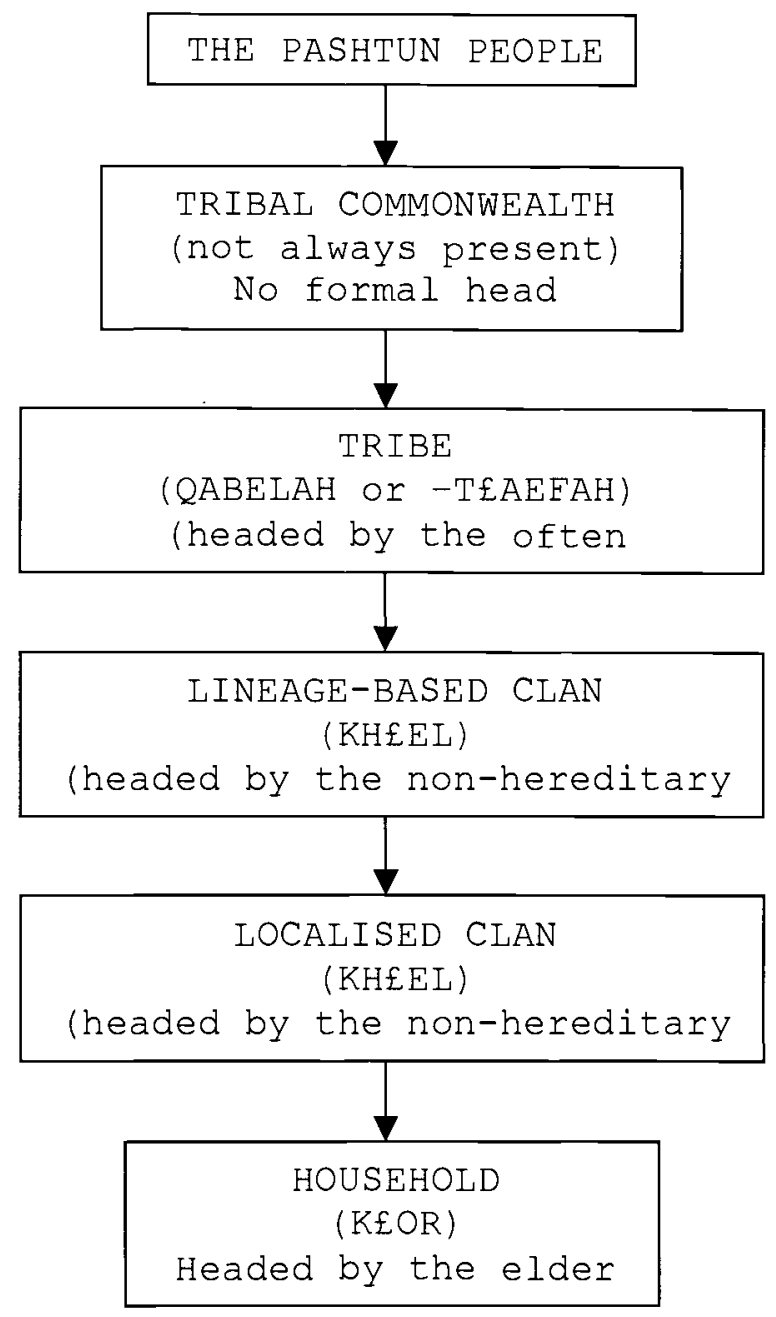

household. Katkov suggests that qawm should be translated as "the tribal people" (plemennoi narod). He describes both qawm and qawmwkal ${ }^{3}$ (the tribal spirit) as a symbol of Pashtun kinship, egalitarianism, communalism and opposition to any kind of state-oriented politics (Katkov, 1989, pp.45-46) ${ }^{21}$. Among the Durranis the term wol $\div$ s (from the Turko-Mongolian kulos, meaning people, tribe, appanage) is constantly used to describe the power of united community effort and the political nature of social groups at a variety of levels (Tapper, N., 1991, pp.30-31, 47).

${ }^{21}$ This concept (based on the views of the Wazir and Safi tribesmen) is identical with Ghilzyas" understanding of qawm as described by Anderson (Anderson, 1983). 
On the household level the patriarchs $(m \div 3 s r)$ exercise all authority. They own or receive the land and represent those of their relatives who have no independent economic or political identity. Individual clients are attached to the $m \div$ "s $s$ s and, as inferior members of the households, surrender their rights with regard to their relations with the outside world. No clan leader (khcan) has the absolute power of a $m \div$ "sr. Kh $c a n s$ do not own land because of their position, cannot give orders to other tribesmen and their children have no legal right of succession. However, the position of a chief of a tribe tends to be hereditary. Although Pashtuns themselves often compare the functions of $k h$ can to those of $m \div$ "s $S$ the similarity between the former and latter lies only in their representative responsibilities. Both of them speak for their "units", either households or clans, when they come into contact with the outside world and lead their followers when their residual unity must be put into action.

Many Pashtuns compete for influence on grounds of economic weight, political connections and personal qualities. However, only those who, as the Ghilzays put it, "feed the people" and "tie the knot of the tribe" are considered as true kh cans. "Tying the knot of the tribe" stands for uniting the tribesmen and asserting the tribal way of life. "Feeding people" implies conversion of personal wealth into social relations through hospitality (i.e. potlatch-type activities) (Anderson, 1983, p.134). Thus the status of a khcan is achieved and maintained through the distribution of patronage and the turning of economic surplus into political capital. Friendliness and hospitality are a part of the display of power since caring for a guest is seen as a sign of strength. Hospitality helps to win allies and boosts social status since by serving his guests the host reduces them, in the eyes of the others, to the status of his dependents, i.e. temporal clients in disguise who for some time lose their independence. Therefore it is important to leave the host quickly and return 
hospitality as soon as possible in order to prove that you are equal in status to your host (Barth, 1965, p.12). Besides, mutual hospitality serves as a travel insurance. Without this guaranteed hospitality a traveller cannot survive in the hostile environment of the country of the Pashtuns (Bellew, 1864, p.210).

The status of $k h$ can changed with the inclusion of tribes in the government's sphere of influence. Since organised non-tribal rule has the means of manipulating the chief by open or disguised bribery khఢans acquire a dual and contradictory function as guardians of tribal traditions ( $q a w m w{ }^{2} I^{3}$ ) and the agents of governmental influence. The $k h$ can also represents his tribe in its relations with the outside world, first of all, the government, which in return may supply the khcan with the resources necessary for him to function - wealth for patronage and connections for mediation as well as titles and honours which help him to boost his status within his group. In this case khఢan-khఢels (clans of chiefs) acquire particular importance. No one outside this clan can become the khఢan of the tribe. In these hierarchically organised tribes (rotbaw $w^{3}$ - rank, hierarchy) the jergah (the tribal assembly) has less political weight and chiefs can impose their political will on the "rank and file" tribesmen. In more egalitarian tribes $\left(q a \mathrm{wm}^{3}\right)$ kh hans do not necessarily belong to khלan$k h \xi e l s$ and their power is subordinate to that of the tribal assembly. Nomadic tribes lack the institution of chief since all political and economic activity gravitates around the different households (Katkov, 1989, pp.54-55).

The complexity and diversity of Pashtun society does not permit limiting its study to only one "generative model ${ }^{22,}$, or type. Therefore three types ${ }^{23}$ of Pashtun

\footnotetext{
${ }^{22}$ This term was introduced by Fredrik Barth in his pioneering study of Pashtun society. He argues that "generative models" "... provide a kind of understanding and explanation which a model of form, however meticulous and adequate, can never give. To study form it may be sufficient to describe it. To explain form one needs to discover and describe the processes that generate the form" (Barth, 1981, vol.I, p.33). This "ideal type" essentialisation, as well as Chomsky's and Levi-Strauss' "structures" which probably provided a theoretical background
} 
society should be considered. One deals with more complex hierarchical society, which exhibited social stratification caused by agricultural surplus. Usually this society produced a ruling class of Pashtuns owning the land and dependent groups working it. The best-described example is the Yusufzays of Swat. Another type involved marginal agriculture or pastoralism in low-production areas with egalitarian communal social forms. Typical are the tribes of Afridi, Mohmand and Wazir. Societies of both types were equally remote from urban centres of organised power, nowadays states. A third intermediate form of Pashtun society was to be found in the areas more accessible to cities and rulers, and where agriculture was reasonably productive. Here the influence of the government produced a feudalistic, "Asiatic" stratification, involving a chiefly class with limited powers, a broad mass of tribesmen and a substratum of clients. Many Durrani groups were of this type (Tapper, 1983, pp.43-44); medieval Khattak principality also provides a good example of this type. Distinction between what was described as "democracy" and "aristocracy" within Pashtun tribes was first made by Sir Mountstuart Elphinstone in his classical account of Afghanistan. He described Pashtun society as comprising both egalitarian and hierarchical forms. He explained this diversity by the varying relationships between tribe and state (Elphinstone, 1839, vol.I, pp.210-235). Subsequent authors, who unlike Elphinstone are not historians but social anthropologists, have identified different forms of Pashtun social organisation as belonging to specific ecological areas (Barth, 1981, pp.103-120; Davies, 1932, pp.51-52 $)^{24}$. At the same time it has been argued that

for Barth's methodology, has been out of fashion in social anthropology for a couple of decades. Nowadays the main focus is on "explanation of the forms". However, because of the scarcity of original sources in the case of Pashtun studies this goal is not always attainable.

23 "Socio-political forms" according to Richard Tapper (Tapper, 1983, p.43).

${ }^{24}$ Akbar S. Ahmed contrasts two different types of the Pashtun organisation which constitute "antithetical forms" and "binary oppositions". While the life of the tribes described by other authors as "egalitarian" focuses on the principle of honour (nang), "hierarchical" groups are concerned with the appropriation of land rent or taxes ( $q a$ lang). The first type of tribes can be found in the low-production areas of the Tribal Agencies and the second in the fertile 
all types of Pashtun society are endowed with one or another kind of coexistence and conflict between equality and hierarchy (Christensen, 1981, p.107). It seems that this combination of the two opposing principles and constantly shifting balance of power between different centres of gravitation within tribes was the main engine of Pashtun tribal history throughout centuries. Anyway, the above-mentioned categorisation of Pashtun society in terms of equality or hierarchy provides only a useful heuristic paradigm for an understanding of organisational variation in the tribal society and should be considered only as such.

Thus, the idea of clan and tribe symbolises unity defined by descent, which replicates itself in the course of time. At the same time individual political interests find their expression in the concept of politically corporate factions or blocs ${ }^{25}$. The breakdown into these "parties" can occur at any level, both individual and collective (i.e. clan-based) (Anderson, 1983, pp.125, 129, 131) ${ }^{26}$. Under normal circumstances these blocs are usually headed by chiefs who, by ammassing the number of their supporters and/or clients, boost their social and political status.

plains and valleys (Ahmed, 1980, pp.116-118). However, this view was refuted by a number of anthropologists who argue that the nang and qalang principles do not explain the essence of tribal types. Besides, according to Asger Christensen and Charles Lindholm both tribal types share a number of similar features (Christensen, 1981, pp.97-98, 107-108; Lindholm, 1993, p.825). I.E. Katkov denies any possibility of establishing nang/qa lang dichotomy since Ahmed does not take into consideration the semantic value of both terms. Nang is a moral and socio-regulatory (as well as political [S.A.]) concopt, while qalang is an economic notion (Katkov, 1989, p.53).

${ }^{25}$ Gund in Pashto, literally "party".

${ }^{26}$ The Pashtun oral tradition accounts for the origin of this division in the following way: "In the fourteenth century a chief of the Bangash tribe, Ismail by name, had two sons, Gar and Samil, whose quarrels led to the tribe being split up into two great factions which still exist under these names. Bangash or Bankash means "root-destroyer", and this was adopted or bestowed as the tribal name by reason of the enmity aroused between the rival factions. The distinction then established still remains, and affects almost all the surrounding tribes; and some Sunnis by religion are Samil in politics, and some Shiahs are Gar, while sometimes both cases are reversed ..." (Wylly, 1912, p.15).

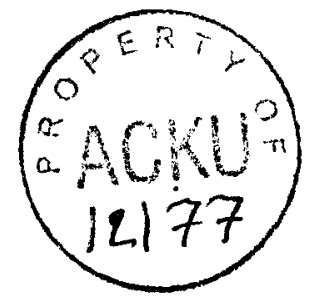


Factions always fuse into two hostile blocs. These coalitions are formed as a result of the alliances between the leaders of the smaller groups aimed at the collective defence of their respective interests and against all outsiders. These coalitions have a permanent character and it is impossible to support an ally in one situation and oppose him in another ${ }^{27}$. These larger coalitions as well as smaller groups are concerned only with the defence of political interests - mainly land disputes. Matters of personal honour are the separate concern of the individuals and their blood relatives. Only strong and wealthy individuals who are able to defend themselves because of the sheer number of their personal clients can allow themselves to stand outside the alliances. Weak and poor people are forced to join the blocs to defend their interests. There are only two options available for this category of Pashtuns: to be somebody's allies or clients. "Neither the state nor your neighbour could be counted on to defend your life and your rights if your were weak. Any property or privilege an Afghan claimed, he would have to secure and defend for himself; and any assistance he obtained from others would depend on what he could offer in return. The strong person, the one who had honour and self-respect, was able to defend himself and had most to offer as a friend or ally ... your life and security and that of your family - depend squarely on your own force and standards" (Barth, 1987, pp.189-190).

Defence of land and personal honour is not a matter of government bodies or tribal chiefs. It is the sole responsibility of the threatened party. Thus while defending his personal honour every Pashtun is supposed to assume the role of both a judge and

\footnotetext{
${ }^{27}$ Personal rivalry between members of the same alliance (they are called m $c$ arez (ill)) does not affect their political alignment and scores between individuals are settled outside their political factions (Barth, 1965, p.111). However all blocs are infested with internal competition for leadership. This is the main reason why the weaker alliance never loses completely. When one of the subsidiary leaders realises that he does not stand any chance of taking over his bloc he deserts with the party of his followers to the rival weaker faction and becomes its leader. Thus the balance of power is changed in favour of the previously weaker alliance (Barth, 1965, pp.112-113).
} 
a law-enforcement officer; the latter usually means executioner. In all honour-related conflicts close relatives should support each other against distant relatives, and all relatives should support each other against outsiders ${ }^{28}$. Since ultimately all Pashtuns are considered relatives they are all expected to unite in the time of foreign invasion.

A person outside tribal structures is absolutely defenceless. His inherited plot of land or share in a communal land property is the basis for his political participation in his kinship or alliance-based group. Acquired property or residence rights cannot give him full tribal membership. Thus, individual migration from the ancestral land in effect signifies an important loss of social and political status and threatens personal security.

A reputation for force and violence and their permanent display are necessary for the survival in Pashtun society. This practice discourages enemies, viz. potentially everybody outside somebody's immediate family, from assaulting the life and dignity of the Pashtun.

Blocs' activities have a reactive character. Alliances are activated only when they have to address a specific political issue. At other times factions are almost invisible since their members are dispersed over vast territories. Therefore blocs do not develop any administrative structures and do not pursue long-term political goals. However, this is only one of the reasons why blocs do not develop into quasi-state structures. Barth accounts for the following disruptive forces which prevent the emergence of a rigid organisational framework: the equal division of land and other property (and thus potential political strength) among sons; constant blood feuds;

\footnotetext{
${ }^{28}$ This practice is well in line with the often-cited Middle Eastern maxim: "Me against my brother; my brother and I against our cousin; and the three of us against the world".

In this respect it is noteworthy that in the Pashto language the word for cousin is $t \div$ rbcur, the addition of a suffix -ganay or -galw $w^{3}$ creates a compound word $t \div$ rb $\nmid u r g a l w^{3}$ or trabgan ${ }^{3}$, which literally may be translated as cousin-hatred and denotes the worst kind of hatred as well as cousinship (Aslanov, 1966, p.223; Barth, p.191; 1987; Dupree, 1984, p.269).
} 
rapid increase of the number of opponents in contrast to the slow increase of the number of followers of an influential leader; opposition of other leaders to the acquisition of personal power by any individual. These pressures result in a situation when "... any expanding centralized unit within the acephalus alliance system must experience strains which eventually lead to its dissolution"' (Barth, 1965, pp.125-126). Often inter-bloc rivalry erupts into fighting. Death in inter-bloc battle does not call for blood revenge. Therefore the struggle between alliances does not take the form of vengeance. Members of various factions fight only to protect their political interests.

O'Ballance gives the following description of traditional Pashtun warfare: "In time of wars and alarms, the small number of regular household troops (of influential and wealthy chiefs [S.A.]) were reinforced by hordes of armed tribesmen ( $1 a_{\text {, skar }}$ [S.A]), ever eager to turn out for a short fight, especially if there were good prospects of loot. Tribal or group affiliations with local warlords were precarious and changeable.

Normally, when called upon, tribal or group warriors would turn out with their own arms and sufficient food for a few days, after which, if the warlord wanted to keep them in the field, and especially if there was no sign of ready loot, he would have to feed and pay them. These levies and volunteers were unreliable on campaign, often reluctant to rush into battle and risk loosing their own valuable horses and weapons, unless they saw rich pickings.

Each Afghan fighting man regarded himself as a free person, to come and go as he pleased, and moreover, to switch allegiances as might be convenient. The main tactic was to make a massive, all-out wild charge at an enemy group to overwhelm it quickly; if successful, thereafter all discipline and military cohesion were lost as it became every man for himself in a gigantic looting spree. Only regular mercenary elements retained some discipline, and were expected to make a counter-charge. If the 
first charge failed, local warriors would fade away to the safety of the hills. While they could be fairly good at laying ambushes on their home ground, they were usually hopeless in protracted defence" (O'Ballance, 1993, pp.5-6). Tactical coordination in battle is achieved by collective consultations of the leaders of the separate war parties. This military coordination does not lead to the establishment of the instutionalized forms of command and hierarchy among the officers. Temporal war-leaders elected by the jergah (they are called camers) command the la "skars. They resign all their authority when the war is over and war-parties disintegrate (Ahmed, 1984, p.197; Elphinstone, 1839 vol.II, p.282).

Before hostilities between two blocs erupt into a full-scale military confrontation the opposing parties try to negotiate their differences in a tribal assembly (jergah). According to Barth only the full and equal tribesmen who hold land in their own name, i.e. the heads of households are allowed to speak at jergah. Assemblies are summoned on an ad hoc basis to address particular questions. The final decision of the jergah should be unanimous. Members do not vote but discuss the issue until there is no opposition to the motion. This consensus is reached either by compromise or by the fear of provoking the anger and retribution of a more powerful bloc. A man or a party who wins the case is assured of the support of his or its allies while the other bloc is obliged to withdraw its support from the loser. Therefore this individual or party stands alone and has no chance to resist. Thus, it appears that Barth is correct in his description of jergah as an institutionalised form of arbitration, not a governing body, which has no power to make or enforce its decisions outside the bloc system (Barth, 1965, pp.115-119). Katkov distinguishes two types of jergah: sabhah-jergah (the assembly of the people) and samt ${ }^{3}$ or samet ${ }^{3}$-jergah (the assembly of the authorities). Sabhah-jergah deals with the affairs of a single village or clan. Everyone, even women, are entitled to 
participate in this assembly (Katkov, 1989, pp.42-43). Although Katkov does not deal with bloc politics it appears that sabhah-jergah is concerned with bloc differences. Samt ${ }^{3}$-jergah, on the contrary, represents the clan or a tribe as a whole. Only Pashtun heads of the households and members of the class of the ôulamkaé can speak at this meeting. Unlike Barth Katkov thinks that all people concerned with the issue discussed at the assembly can participate in the sabhahjergah. Since Barth does not account for the two distinct types of jergah it is possible that his description deals with the samt ${ }^{3}-$ jergah only $^{29}$.

Thus, Pashtun social life is dominated by three different factors: kinship-based hierarchical loyalty and segmentary political opposition expressed in bloc politics as well as the influence of $k h \xi a n s$ which is stronger in less egalitarian tribes.

\subsection{MAJOR LANGUAGES OF AFGHANISTAN AND THEIR LITERARY TRADITIONS.}

The Iranian languages are best represented in Afghanistan followed by the Turkic languages, and then by the Indian languages, which are either native to the area, viz. Kafir and Dardic, or imported like the New Indian languages.

Most Afghans who are not native Dari-speakers are more or less bilingual in their native tongues and Dari.

By the royal decree of 1936 Dari and Pashto were granted the status of equal official languages, the principle confirmed by all subsequent Afghan constitutions. However, despite all the attempts to promote Pashto and the relative numeric

\footnotetext{
${ }^{29}$ Discrepancies between Barth's and Katkov's accounts of jergah provide a good illustration of the differences between various Pashtun tribes. Barth's description of jergah is based on his fieldwork in the hierarchical society of the Yusufzays of Swat while Katkov refers to the situation in Afghanistan.
} 
superiority of the Pashtuns Dari seems set to occupy a dominant position as a language of culture and administration as well as the nation's koine.

In 1980 five more languages were granted the status of "national languages", namely Baluch, Uzbek, Turkmen, Pashai and Kati (called Nuristani in the decree). In 
*Chart 3. Iranian and Indo-Aryan languages of Afghanistan ${ }^{\star}$.

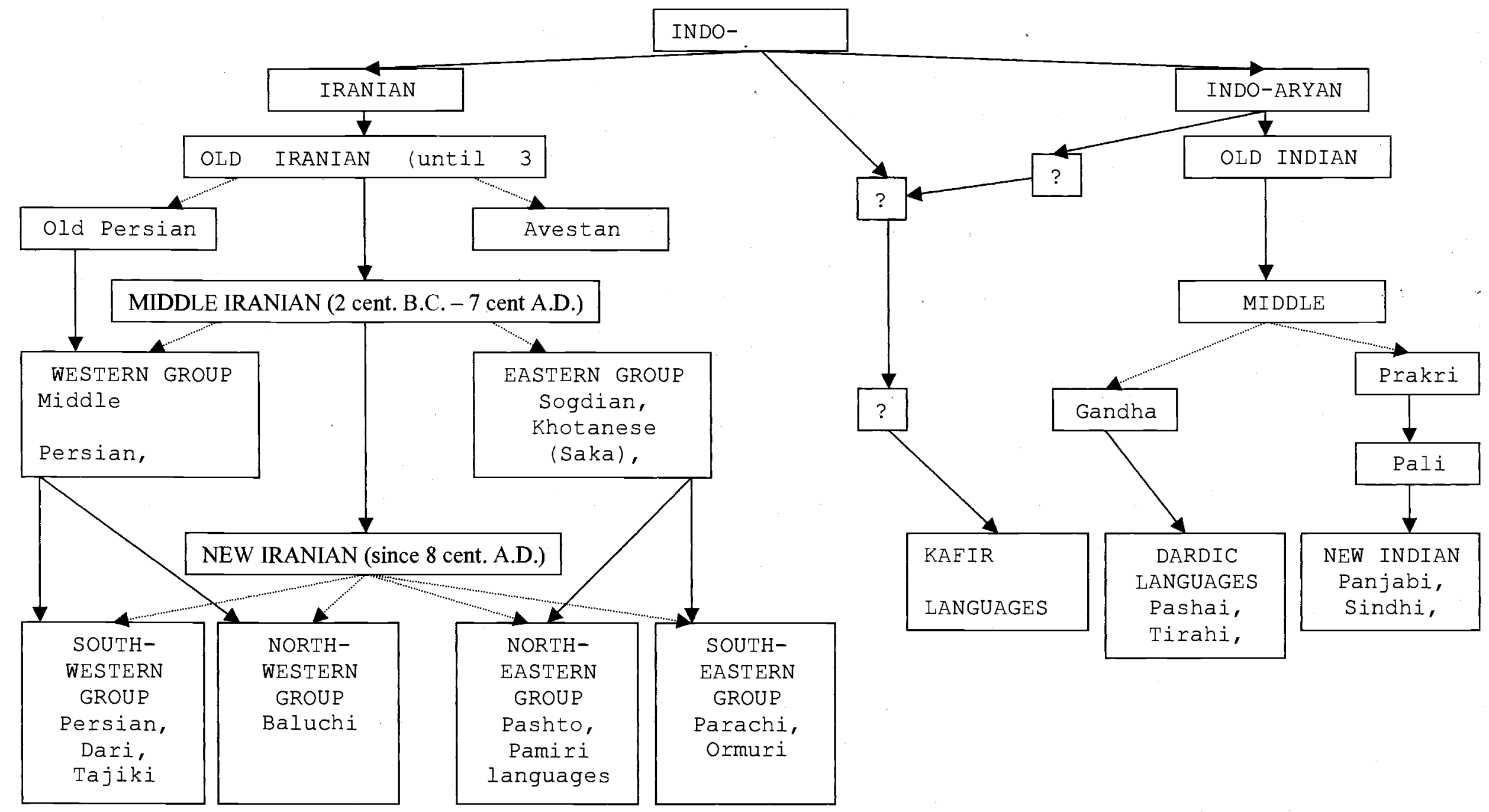

* Based on Keiffer, 1985, p.504.

Solid line designates origin, dotted line designates relation to a certain group 
the 1980's there were successful attempts to start primary education, broadcasting and publishing in Baluch, Uzbek and Turkmen.

Though both Dari and Pashto are Iranian languages they are not mutually understandable for they belong to two distinct groups, the former to the South-western group and the latter to the North-eastern. Apart from different vocabularies these two languages have dissimilar grammatical structures with Dari being an analytical language and Pashto a synthetic one.

Both official languages possess a considerable number of dialects; Pashto to a degree of lacking the "normative" standard. The Pashto dialects are usually divided into "hard" (or maghreb (western) or Kandahari [A]) and "soft" (or ma "sreq" (eastern) or Jalalabadi $[\mathrm{C}]$ ), some linguists also introduce an intermediary dialect $(\operatorname{manjan\div y}[\mathrm{B}])$. This classification is based on the differences in the treatment of " $-s, "-z, " z$ (soft) and "x, "g, j (hard). The "B" dialects are not characterised by the generic pronunciation of the phonemes differentiating " $A$ " and "C" but rather present a number of divergences that appear to be original ${ }^{30}$.

Dari dialects are abundant and can be grouped into four main types (A, B, C, D) ${ }^{31}$ differing in phonology, morphology and syntax.

Dari literature is based on the colossal legacy of classical Persian literature shared by the speakers of Dari, Persian and Tajiki. However, after the severance of cultural contacts with Iran following the establishment of the Durrani confederacy in 1747 the development of Afghan Dari literature was influenced by the "Indian style" $\left(s a b k-e h^{3}\right)$, which set a new pattern quite different from the Iranian tradition, but nevertheless common for Muslim India, Central Asia and Afghanistan. Apart from developing poetry along the lines set by the great Indian Persian poet $M^{3} r z$ \& $a$

\footnotetext{
${ }^{30}$ For more details on the spread of various Pashto dialects see the section "Pashtuns".

${ }^{31}$ For more details on the spread of various Dari dialects see the section "Tajiks".
} 
ôAbd al-Qłader $B^{3}$ del (1644-1720), Dari literature also focused on historiography and hagiography.

Modern writing and journalism in Afghanistan begins with Ma-hm\&ud $-\operatorname{Tarz}^{3}$ (1865-1933), who spent his youth in Damascus and Istanbul. Thus he diverted the development of Dari prose from the well-established sabk-e hend ${ }^{3}$ pattern and moved it closer to the Middle Eastern tradition.

Pashto literary tradition undoubtedly starts with the prolific intellectual activity caused by the $\operatorname{Raw}_{n} \times \mathrm{q}^{3}{ }^{3}$ movement (circa $\left.1560-1640\right)^{32}$. This independent tradition of writing in Pashto was further developed and consolidated by the renown warrior-poet Khלo,sh६al Khלan KhaŸtŸtak (1613-1689). Until the 1950's poetry remained the main genre of Pashto literature. Although it was heavily influenced by Iranian and Indian literary Persian traditions, given the peculiarities of the Pashto language - notably the lack of a clear distinction between short and long vowels, which makes a differentiation between short and syllables almost impossible, and the fact that clusters of two or even three consonants occur, usually at the beginning of a word - the Pashto metres are not quantative. Nevertheless, many Pashto authors tried to imitate certain aspects of ôaruz, but in a rather clumsy way. The meter of Pashtun folk songs, where the feet are marked by regular patterns of accents, fits Pashto poetry more naturally. Therefore, those authors who unashamedly adopted folklore poetical forms usually wrote the more eloquent poetry.

Radio was introduced in Afghanistan in 1940, and television in 1977.

\footnotetext{
${ }^{32}$ The 1960's attempts of the Pashto Academy in Kabul to trace the origin of the collection of Pashto poetry $\mathrm{P} \div \dot{\mathrm{Y}} \operatorname{tah}$ Khazcanah (The Hidden Treasure) to $8^{\text {th }}$ century should be dismissed as a hoax.
} 


\subsection{MAJOR ETHNIC GROUPS.}

The ethnic composition of Afghanistan is characterised by extreme ethno-linguistic and physical diversity with 55 ethnic names found there (Orywal, 1986, pp.9, 18-19). Many of these ethnic groups and identities are local categories only. They are relative, variable and dynamic. Except in rural areas away from the main lines of communication few ethnic groups maintain racial homogeneity; though Pashtuns are less affected by the influx of foreign blood. Many groups, especially in the north of the country, have practiced intermarriage for centuries, thus composite ethnic communities exist in broad bands of ethnic grey zones. Therefore, Afghanistan is not a self-contained ethnic unit, nor is it national culture uniform. Very few of its ethnic groups are totally indigenous: Pashtuns break almost equal among Afghanistan and tribal agencies and the North-West Frontier Province of Pakistan. Tajiks, Turkmens, Uzbeks and Kyrgyz have their own countries. Most inhabitants of far western Afghanistan, which geographically and culturally is an extension of the great Iranian plateau, are Persian-speaking $F \xi a r s^{3}$ w $\xi a n$. The Baluch of the southwestern corner of Afghanistan extend into the neighbouring areas of Pakistan and Iran with a few settlements in Turkmenistan.

The majority of Afghans are Sunni Muslims of - $\operatorname{Hanaf}^{3}$ madhhab, though there are a significant Imami Shiite and a smaller Ismaili minorities ${ }^{33}$.

\subsubsection{IRANIAN PEOPLES.}

Iranian peoples ${ }^{34}$ constitute the largest supra-ethnic entity in Afghanistan. In accordance with their languages they are divided into the speakers of Eastern and

\footnotetext{
${ }^{33}$ For more details on the religious composition of Afghanistan see the section "Peculiarities of Afghan Islam. Sunnites, Shiites, Ismailis and Sufis".
} 
Western Iranian languages, with Pashtuns, Ormurs and Parachi being the former and the rest the latter.

\subsubsection{PASHTUNS.}

Pashtuns $^{35}$ are the dominant ethnic group in Afghanistan, which is concentrated mainly south of the Hindukush mountain range but also found in the west and north of the country, partly due to the late $19^{\text {th }}$ century resettlement policy pursued by Emir ôAbd al-Ra-hm\&an, who thus consolidated his power-base in the newly acquired territories. Their exact number and ratio can be only estimated and there is a wide range of statistical data, which is often politically motivated, ranging from 4.5 to 10 million people (from $40 \%$ to $60 \%$ of total population), who are engaged in agriculture, sedentary and nomadic pastoralism. The bulk of Pashtuns are Sunni Muslims of - Hanaf $f^{3}$ madhhab, though there are some Shiite Pashtuns as well ${ }^{36}$.

The origin of the word "pa "xtcun" is unclear, though the once popular theory of connecting the Pashtuns with the Iná $\chi \tau v \varepsilon \varsigma$ of Herodotus should be rejected on linguistic grounds. They are also known by the Persian/Dari designation Afghcan, which is of unknown etymology and dates back to the pre-Islamic times. For the first time Pashtuns were probably referred to as Avagcana by the early $6^{\text {th }}$ century Indian astronomer Varkaha Mihira in his B-rhat-sa-mhitלa. A little later there is another possible reference to them in the famous "Life of HiuenTsang". The first Muslim work undoubtedly mentioning the Pashtuns is the -Hud`ud al-ô£Alam (982 A.D.), which was followed by a number of other well-

\footnotetext{
${ }^{34}$ Not to be confused with the citizens of Iran; in this context Iranian denotes belonging to a certain family of Indo-European languages like it is the case with e.g. Germanic or Slavonic.

${ }^{35}$ Self-appellation $p a$ "xt tun (singular), pa "xt $\operatorname{con} \div$ (plural).

${ }^{36}$ The Turi Pashtuns and some Orakzay and Bangash tribes, according to the British Indian sources, some of them converted to Shiism only in the $18^{\text {th }}$ and $19^{\text {th }}$ centuries (Kohat Gazetteer, 1884, p.69; White King, 1984, p.151; Ridgway, 1910, p.159; Rose, 1914, vol. 3, p.177).
} 
known sources in Persian and Arabic. All of them locate the Pashtuns in the Sulayman mountains. However, there is not much information on their early history with only scattering reference to the Pashtuns' participation in the wars of the Indian frontier where they either supported or opposed local non-Pashtun rulers.

Nowadays the Kabul River Basin is the heartland of the Pashtuns, however, it is not their original homeland. In the late $14^{\text {th }}-$ early $17^{\text {th }}$ century this area witnessed three waves of Pashtun migrations. In the early 15 th century the Dilazaks and perhaps the Afridi as well ${ }^{37}$ arrived in the Peshawar Valley. About 1490 the Khashi Khel tribes of the Yusufzay tribal commonwealth entered the area. They were followed by the Ghoriya Khel tribes, the Mohmands, Khalils and Daudzays who moved to the Peshawar Valley in the 1520's. Before they reached a certain accommodation and balance of power in the newly acquired territories the Pashtun invaders had to fight not only against the local rulers but between each other as well.

Before the massive Pashtun invasions the sub-regions to be conquered had a complicated ethnic configuration. Pashtun tribes ${ }^{38}$, Persian-speakers (Tajiks) and a few Turks settled in Nangrahar. The Pashai Laghmanis, Kafirs (later known as Nuristanis) and Tarklanri Pashtuns occupied the districts of Laghman, i.e. Mandrawar, ôAlishang and ôAlinagar. In Kunar lived the Kafirs, Pashais and Turks. The mountains of the Peshawar district were populated by various Dardic and Kafir (Nuristani) ethnic groups each speaking its own dialect or language. The Dardic peoples were usually called after the valleys they inhabited, e.g. Tirahis.

These native peoples lived in stratified peasant societies with the non-Dardic

\footnotetext{
${ }^{37}$ V.A. Romodin and C. Collin Davies are of a different opinion. They maintain that the Afridis lived in Tirah long before the major Pashtun invasion and mixed with the local Dardic people (Collin Davies, 1961, pp.237-239; Romodin, 1964, vol.I, p. 370).

${ }^{38}$ It appears that some tribes had lived in this area for a long time. On his way to India Timur had to pacify the tribes of Pani, Sherani and Lodi (Romodin, 1964, vol.I, pp.368-369).
} 
elite, usually of either Turkic or Arab origin, ruling over the Dardic peasants. Only the elite could exercise political power since only the members of this elite held land and could muster military force. The indigenous Dards were landless peasants, shopkeepers, foot solders and communal servants subject to the rule of foreign masters. Both the rulers and the subjects were Muslims and the traditional model of the authoritarian individual power of a prince was applied.

The inherited weakness of a stratified society ruled by an alien elite proved favourable for the success of the Pashtun invaders who by replacing the former elite began to dominate the indigenous peasants. Besides, the Pashtuns' military organisations based on tribal structures proved superior to the state structure of the little princedoms they conquered. The contact between Pashtun tribal nomads and the native agriculturalists had a stronger impact on the Pashtun newcomers then on their new subjects. The Pashtuns changed their economic and ecological environment and from poor nomads gradually turned into wealthy sedentary landowners. However, this process did not affect their segmentary lineage system, which usually proves to be very resilient with modern socio-anthropological studies bearing witness to its strong survivability. The conquest of non-Pashtun agriculturalists by the predominantly nomad Pashtuns did not immediately lead to the emergence of a state. For a state to emerge, subjugation and conquest must be sufficiently stable and large-scale and the level of social differentiation among both the conquers and the conquered must be adequately high. As a result of subjugation or conquest a super-stratification can emerge, which turns ethnic differences into social ones and may, or may not, lead to the creation of a state ${ }^{39}$. The conquered non-Pashtun population was relatively small and dispersed, had no political affinity with their former rulers and thus lacked

\footnotetext{
${ }^{39}$ For an illuminating discussion on the state formation in tribal and nomadic society see Khazanov, 1984.
} 
political organisation. Therefore their subjugation and exploitation did not require any essentially new forms of organisation or management from the Pashtun nomads ${ }^{40}$. For the native population the difference between their former individual rulers and the new tribal masters was very little since the way of life and economic status of their stratified peasant communities was not affected. In the course of centuries many of these conquered non-Pashtuns were culturally and linguistically assimilated, nevertheless they usually retained their subjugated status of the clients of the tribal Pashtuns for they were never integrated into kinship-based political structures of their patron tribes. Just as before the Pashtun migration, they formed an important segment of the economic system, but the change of the ethnicity and political nature of the elite did not affect their political and social position. This socio-political pattern runs throughout the history of Pashtuns' relations with their non-Pashtun clients/subjects.

Since the Pashtuns were not able to establish their own state structures ${ }^{41}$ even after their expansion from their original homeland in the Sulayman mountains they were soon subjected by the Mughal Empire, though very often the Mughals exercised only nominal control of the unruly tribesmen who continued to trouble the empire with the general unrest, which often undermined the strategically important trade between India and Central $\mathrm{Asia}^{42}$.

Pashtuns are tribal people and their tribal identities are based on common ancestry. There are many medieval Indian and Afghan sources dealing with the

\footnotetext{
${ }^{40}$ If the Pashtuns could rule their new subjects without the state apparatus the natural question is why their non-Pashtun predecessors needed some sort of state? Although we know very little about the life of the native population of the Kabul river basin before the Pashtun invasion it seems reasonable to assume that pre-Pashtun foreign rulers had no tribal background and therefore had to apply an Islamic state model in order to secure their territorial gains.

${ }^{41}$ The S 4 ur and L \&od $^{3}$ Pashtun dynasties in India followed a different pattern of statebuilding (or rather inheriting the state apparatus) in the conquered lands. In any case their history is beyond the scope of this monograph.

${ }^{42}$ For more details on the history of the Pashtuns see the section "Afghan History prior to the End of the Monarchy".
} 
Pashtun tribal genealogy (Akbar-ncamah by Abu al-Fa-zl, Tadhkerah al-Awleycaé by Sulaymcan Mcakcu, Makhzan-e Afghcan ${ }^{3}$ by Neômat Allkah, -Hayat-e Afghłan³ by Mo-hammad -Hayłat Khcan, etc) as well as the British Indian materials based either on the abovementioned accounts or oral Pashtun traditions ${ }^{43}$.

There are two opinions concerning the historical reliability of the Pashtun tribal genealogies. Georg Morgenstierne thinks that they cannot be relied upon as historical sources and serve only as a testimony to the traditions current among the Pashtuns in the $16^{\text {th }}$ and $17^{\text {th }}$ centuries $^{44}$ (Morgenstierne, 1961, p.218), when these genealogies were written down. Unlike him, A.A. Rose maintains that only the most ancient parts of tribal genealogies belong to the realm of mythology while more recent sections are historically reliable (Rose, 1914, vol.3, pp.221-222). Along with this line of argument V.A. Romodin maintains that starting from the $11^{\text {th }}-13^{\text {th }}$ century tribal genealogies correspond to historical reality. He builds his argument on the assumption that it is impossible to alter genealogy (at least with regard to the last seven - ten generations) in a kinship-based society ${ }^{45}$ (Romodin, 1964, vol.I, p.275).

However, there is much evidence to show that genealogies tend to become "compressed" as "unimportant" individuals are dropped out or forgotten. Thus, unlike the above-mentioned scholars, anthropologists demonstrate the constructedness of genealogies which should be considered as ideologies justifying the dominance of powerful groups, with this process of genealogical production being called "must-

\footnotetext{
${ }^{43}$ For a comprehensive survey of the Pashtun genealogical traditions and nationalistic constructs with regard to their historical ideology see K\&akcakheyl, 1999.

${ }^{44}$ Some tribes derive their genealogy from fantastic sources, e.g. members of the Shamuzay clan of the Yusufzay tribe believe that they originate from a fairy ( $\left.p a r^{3}\right)$ (Girs, 1989, p.182). ${ }^{45}$ In the Pashtun society every tribesman in order to prove his status is required to memorise the genealogy of his own clan. Those who fail to comply with this rule are treated as suspicious aliens (Atayiee, 1983, pp.80-81; Atai, 1983, p.6).
} 
have-been" reckoning (Lancaster, 1981), whereby genealogical details are adjusted to fit changing political and social realities. This process among the Durrani clans was clearly described by Nancy and Richard Tapper (Tapper and Tapper, 1982, pp.169170).

Whatever the truth may be, Pashtuns themselves do not doubt their genealogies. Thus the social and psychological implications of these traditions are as real as those of the indisputable historical events. Traditionally Pashtuns can realise their social, economic and political potential only within the tribal structure. Their personal status and security outside their immediate clans is determined by their tribal affiliation. Nevertheless, this is the case not only with individuals. In inter-tribal politics genealogies also rule supreme. Alliances are formed along genealogical lines and political support is given or withdrawn in accordance with agnatic and affinal relations. Genealogies also matter in economic life since land distribution is based on kinship.

According to the common Pashtun tradition, the ancestor of the majority of the Pashtun tribes was Qays who lived at the time of the Prophet Mo-hammad ${ }^{46}$. He travelled to Arabia where he converted to Islam and received the name of ôbd al$\mathrm{Ra}, \mathrm{S}^{3} \mathrm{~d}^{47}$. He was the son of Afghcanah ${ }^{48}$, a grandson of King -Talcut or Scarcul (Saul) of Israel. Sometimes this view of the Jewish origin of the Pashtuns

\footnotetext{
${ }^{46}$ Calculations based on the number of generations which separate Qays from well-known Pashtun rulers of the $13^{\text {th }}-18^{\text {th }}$ centuries reveal that the ancestor of the Pashtuns should have lived in the $10^{\text {th }}-13^{\text {th }}$ centuries, not in the 7 th century (Romodin, 1964, vol.I, p.275). However, because of the above-mentioned "compression" of genealogies the earlier individuals may have lived much earlier than a simple count of generations would suggest.

${ }^{47}$ It appears that this practice of deriving tribal origin from one of the Prophet's companions is common for many Muslim tribes. Thus, the Kirghiz think that their common ancestor was Erke, $\mathrm{s}$, allegedly the standard-bearer of the Prophet Mo-hammad; the Uzbeks think that they all originate from Turk-Tugyan, a contemporary of the Prophet who saved the Muslim army from defeat (Saidbaev, 1978, pp.83-84).

${ }^{48}$ According to another version, 37 generations separated Qays and Afgh $\dot{a}$ anah. The name of Afghcanah is not mentioned in the Bible.
} 
is held independently and is unrelated to the tradition, which derives the origin of the Pashtuns from Qays ${ }^{49}$.

According to tribal genealogies, the Pashtun people are divided into four major branches named after their ancestors. These branches are as follows: Sarbani, Batani (Bitani) or Mati, Ghurghushti and Karrani / Karlani. In the $16^{\text {th }}$ and $17^{\text {th }}$ centuries, when the tribal genealogies were recorded, Afghan and Indian chroniclers enumerated 382 Pashtun tribes. 105 of them belonged to the Sarbani branch; 105 to the Karrani branch; 95 to the Ghurghushti branch and 77 to the Mati branch (Neamet Ullah, 1829-1836, vol.II, pp.40, 122). Only Sarbani and Ghurghushti tribes descend directly from Qays, the bulk of Batani or Mati tribes is connected to Qays through Matco, the daughter of Ba-tan. The Karrani tribes relate to the rest of the Pashtuns through their ancestor Ka-r-rcan, a man of doubtful origin.

Pashtun genealogy is uniform only with regard to its main ancient aspects. Views of the origins of particular groups may vary in different tribes ${ }^{50}$. These discrepancies bear witness to the ideological character of many genealogies. Thus it is interesting not to establish what "really happened" (which is probably impossible), but to see who originally produced these genealogies and who reproduces them now as well as who is making what claims of legitimacy and superiority.

\footnotetext{
${ }^{49}$ Jews lived on the territory of Afghanistan from ancient times (Gnoli, 1962, pp.311-312). However, it is most unlikely that they in any way contributed to the making of the Pashtun ethnos. Nevertheless, well until the end of the 19th century many authors writing on the Pashtuns subscribed to the view that Pashtuns had descended from Jews. They were seen as the descendants of the lost ten tribes of Israel who did not return from the Babylon captivity. However, even in the 1830's Bernhard Dorn proved that Pashtuns and Jews had nothing in common. Surprisingly, even now some journalists, perhaps after uncritically reading just one or two outdated books on Afghanistan, find it possible to contemplate this Jewish connection. so These variations are printed in italics in genealogical charts below. The names of individuals are transliterated and given in capitals and tribal names are in an Anglicised form and in low cases without transliteration because of the irregularity of their spelling. In general, genealogical charts below should be treated as an approximation for it is impossible to record all individual variations reflecting the ideological constructs of different tribes.
} 
Chart 4. QAys and his descendants.

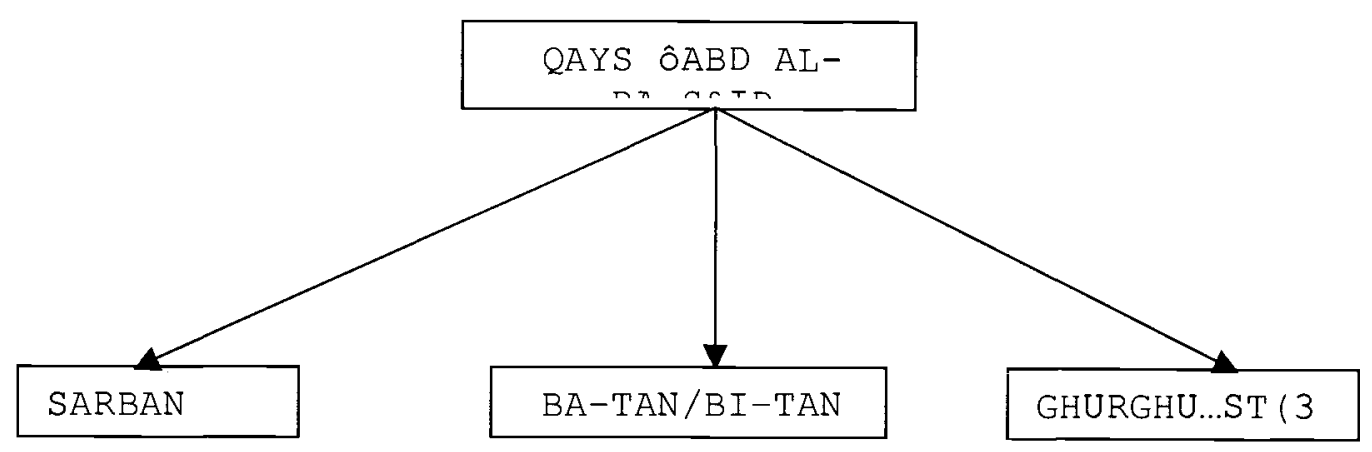

Chart 5. The Sarban line (1)

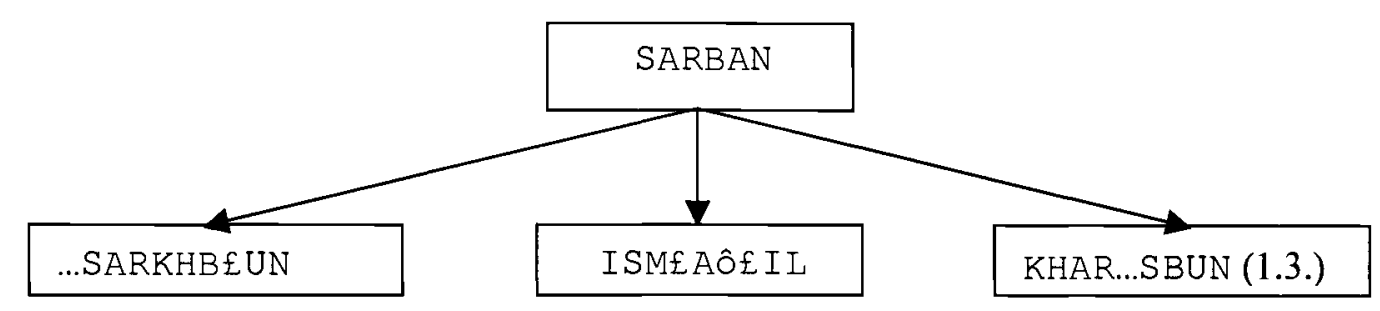

Chart 6. The ...SARkhbלun Lineage (1.1.)

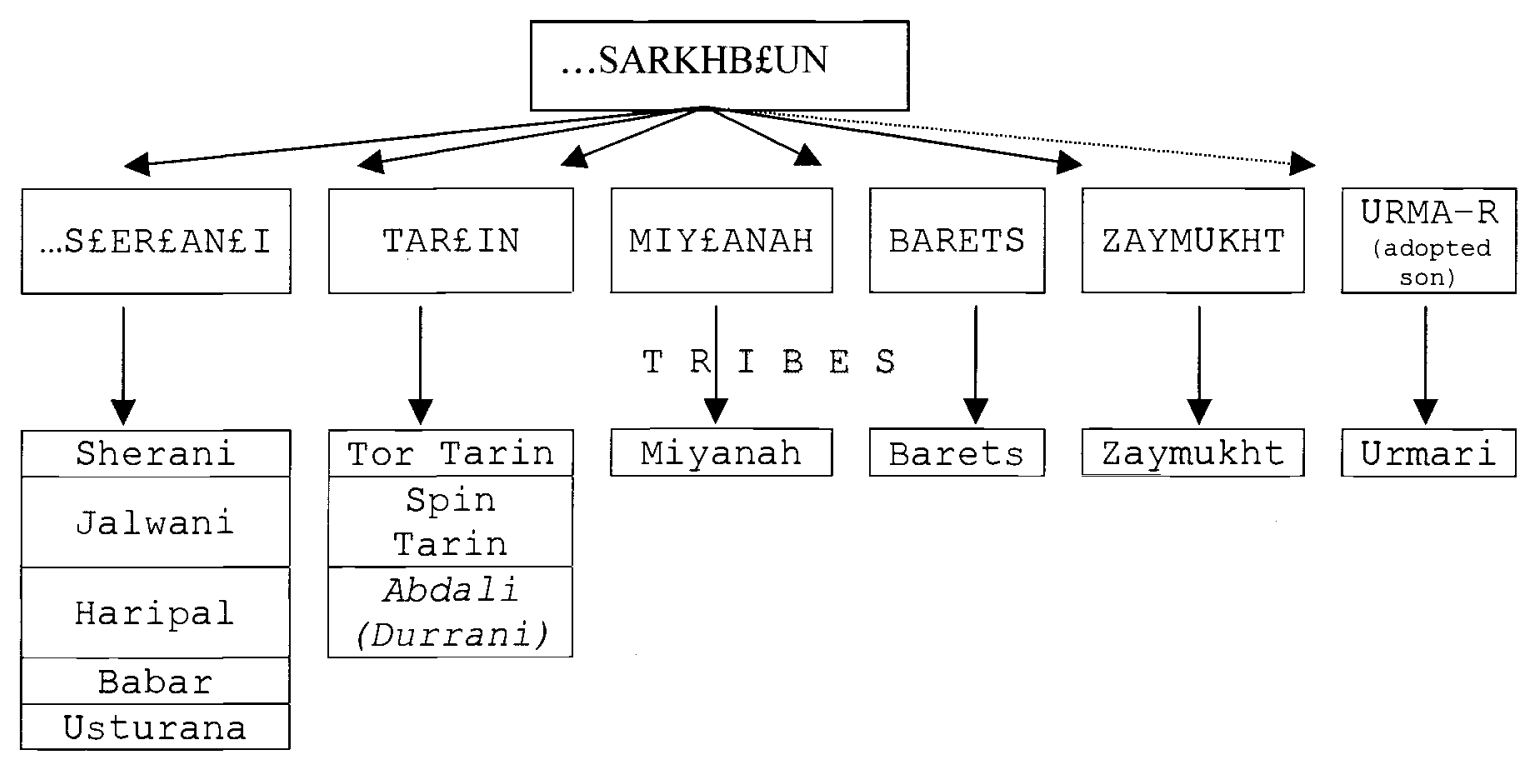


Chart 7. The KHAR ,SBלUN Lineage (1.3.)

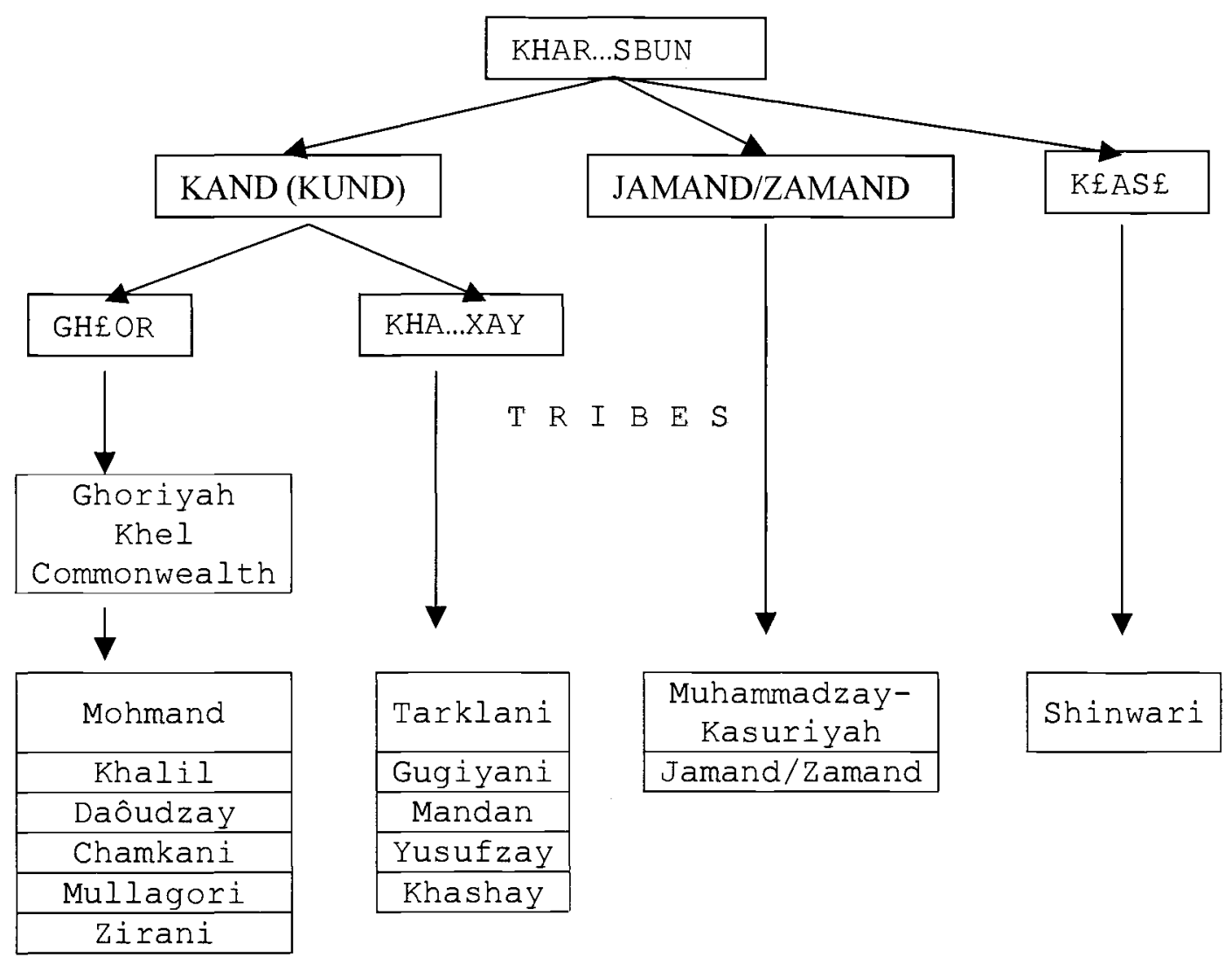


Chart 8. The Batan/Betan line (2).

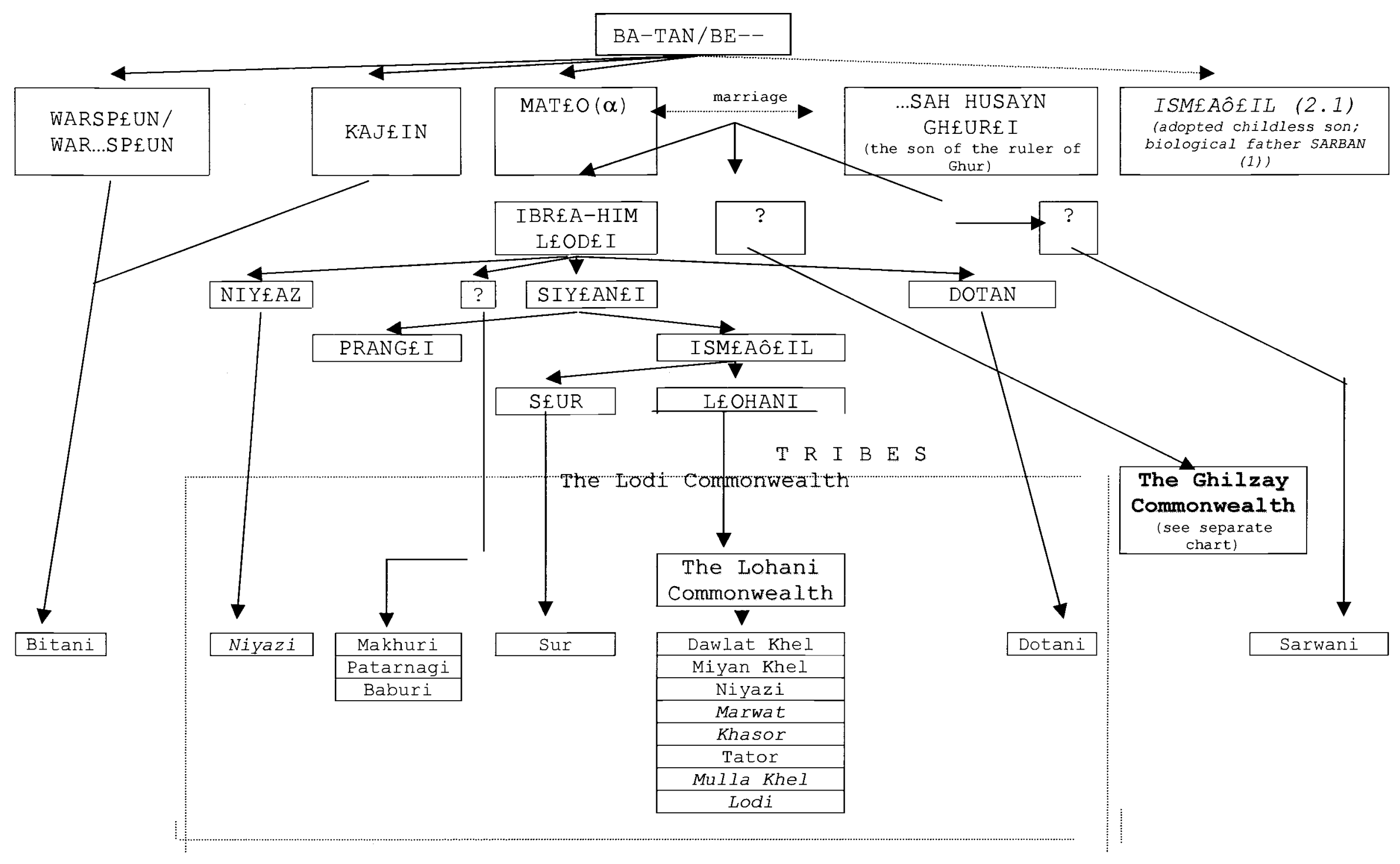


There is also a different version of the genealogy of the tribes originating from Matco.

Chart 9. The Mateo lineage.

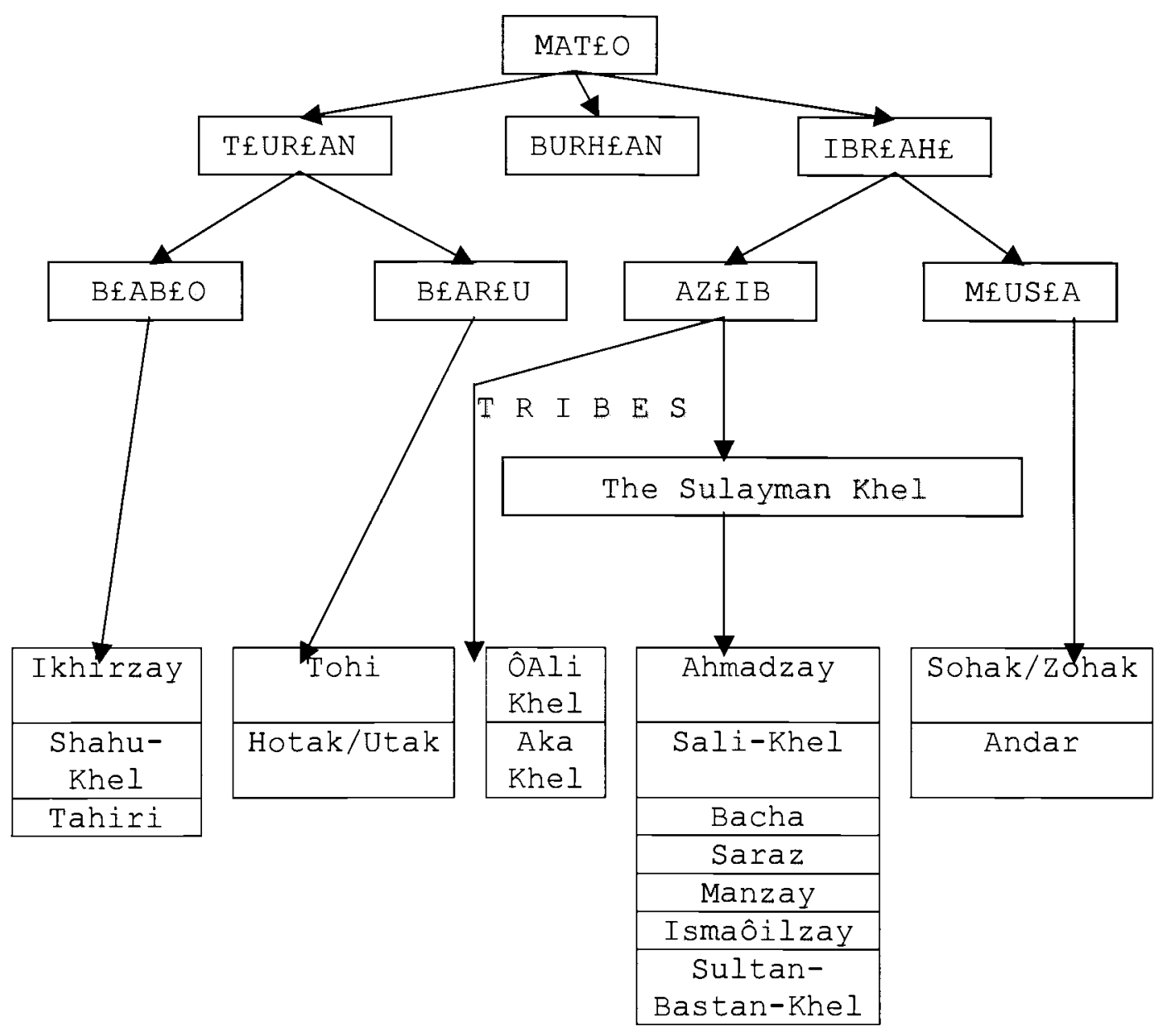


There is also another version of the genealogy of the descendants of Thurcan and Ibrkah ${ }^{3} \mathrm{~m}$ who from the Ghilzay tribal commonwealth.

\section{Chart 10. The GHilzay commonwealth.}

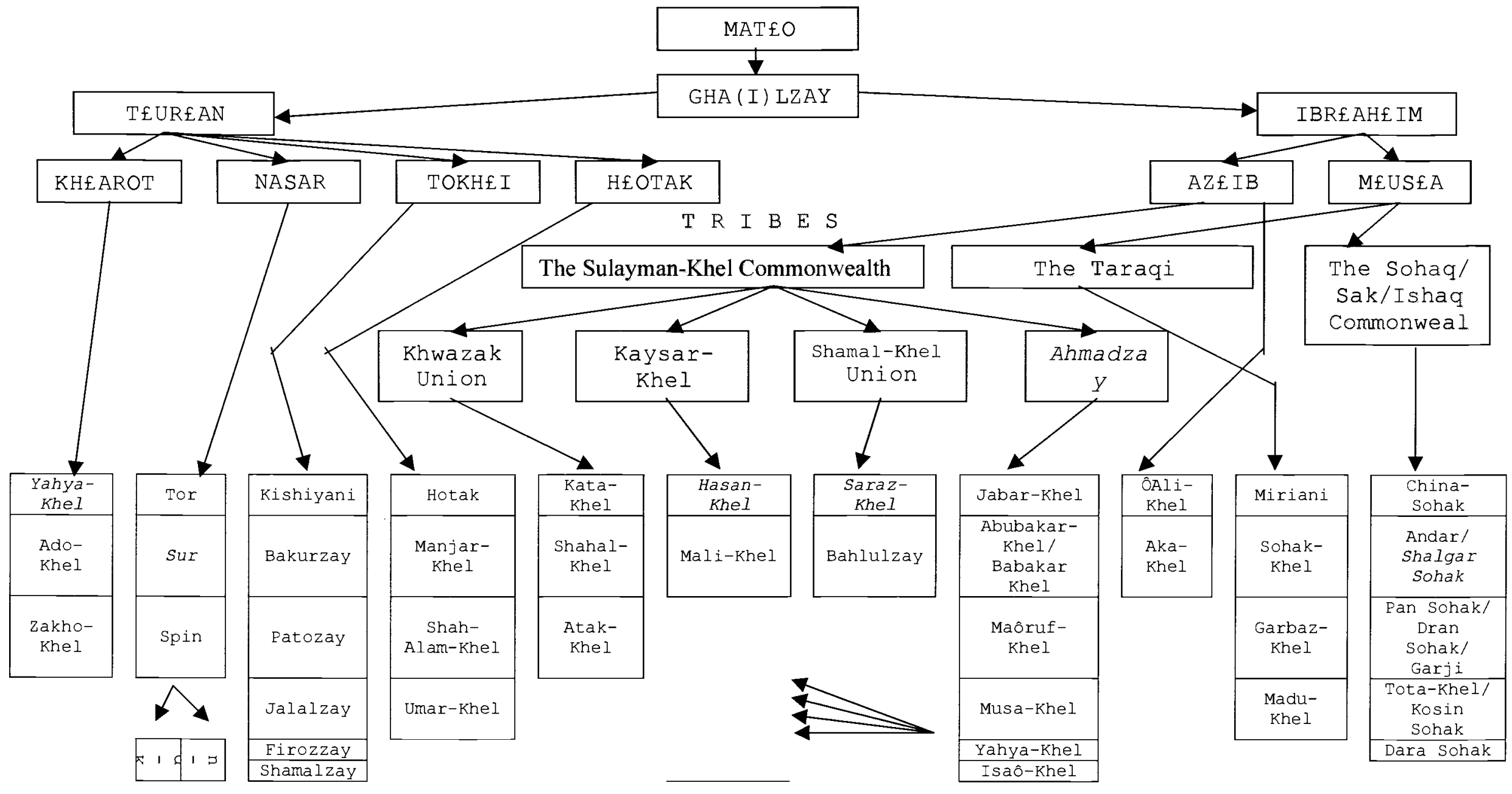




\begin{tabular}{|c|}
\hline $\begin{array}{c}\text { Ibrahim- } \\
\text { Khel }\end{array}$ \\
\hline Mirgutay \\
\hline $\begin{array}{c}\text { Bahram- } \\
\text { Khel }\end{array}$ \\
\hline $\begin{array}{c}\text { Khurani- } \\
\text { Khel }\end{array}$ \\
\hline
\end{tabular}

\begin{tabular}{|c|}
\hline $\begin{array}{c}\text { Allah Din- } \\
\text { Khel }\end{array}$ \\
\hline $\begin{array}{c}\text { Zandak- } \\
\text { Khel }\end{array}$ \\
\hline Dandi-Khel \\
\hline
\end{tabular}


There are two versions of Ismcaôil's (1.2) lineage. According to the first one he died childless, according to another he left numerous descendants.

Chart 11. The Ismçấfil LINEAGE (1.2.)

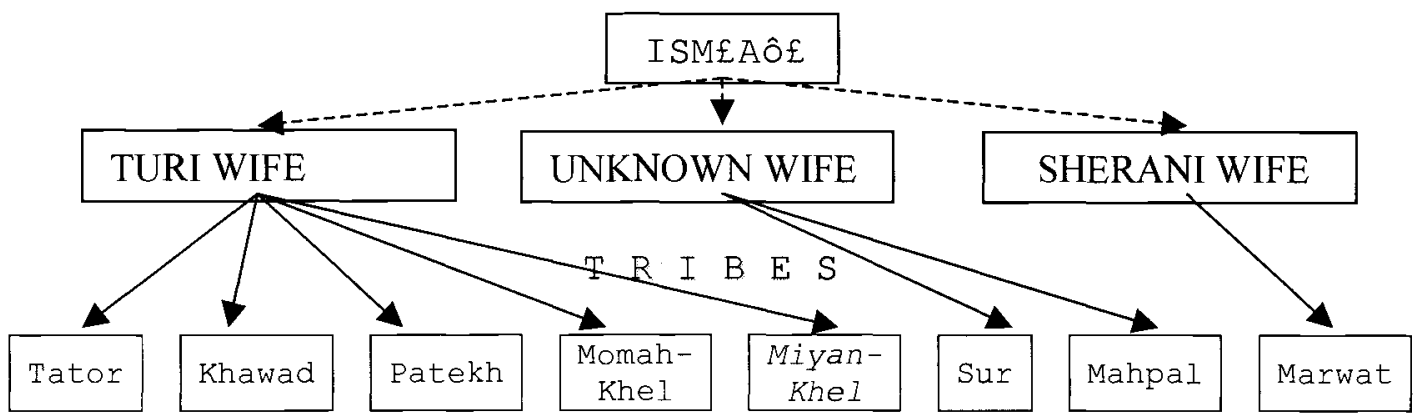

Chart 12. The Ghurgu...st Line (3)

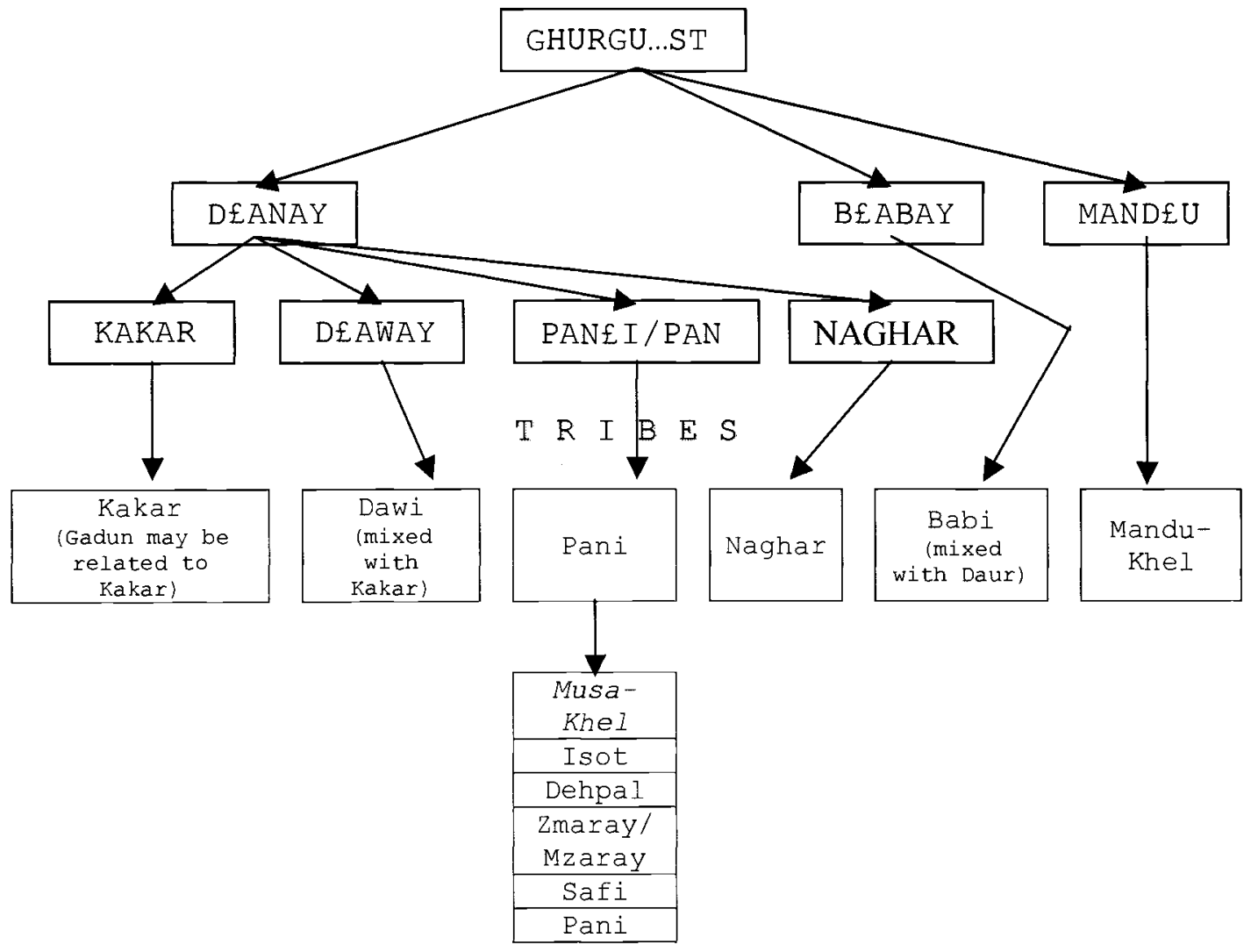


There are two different versions of the origin of Ka-r-rkan (Karlian). According to one of them, he is the son of Burhian and thus the grandson of Ghurhgu "st. According to another version, he was found by an Urmari tribesman and adopted by his brother who had no sons.

Chart 13.1. The Karrani / KarLani commonwealth.

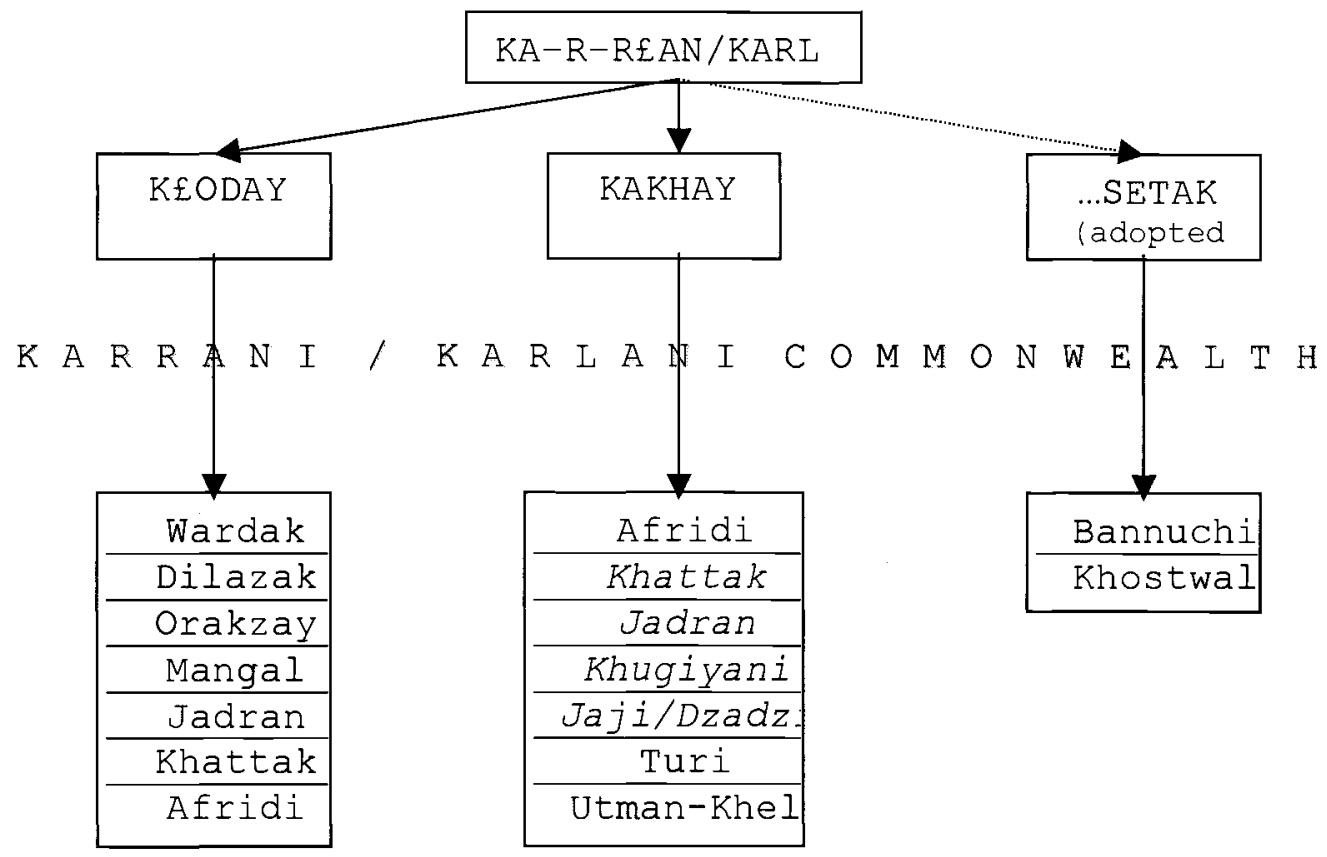

There is also an alternative genealogy.

Chart 13.2. The Karrani / Karlani commonwealth.

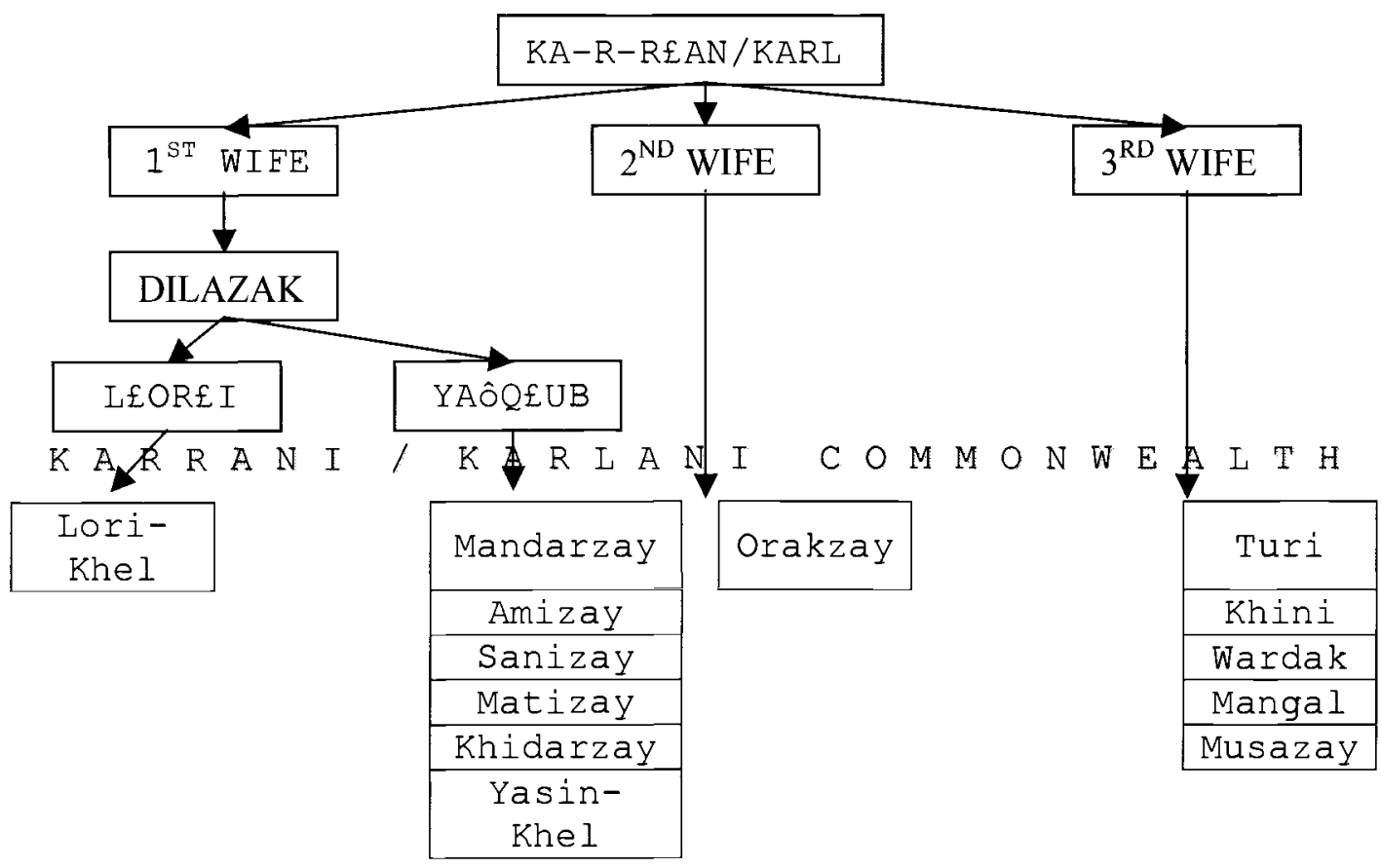


There is also one more version of the genealogy of the Karrani/Karlani commonwealth.

Chart 13.3. The KarRani / Karlani commonwealth.

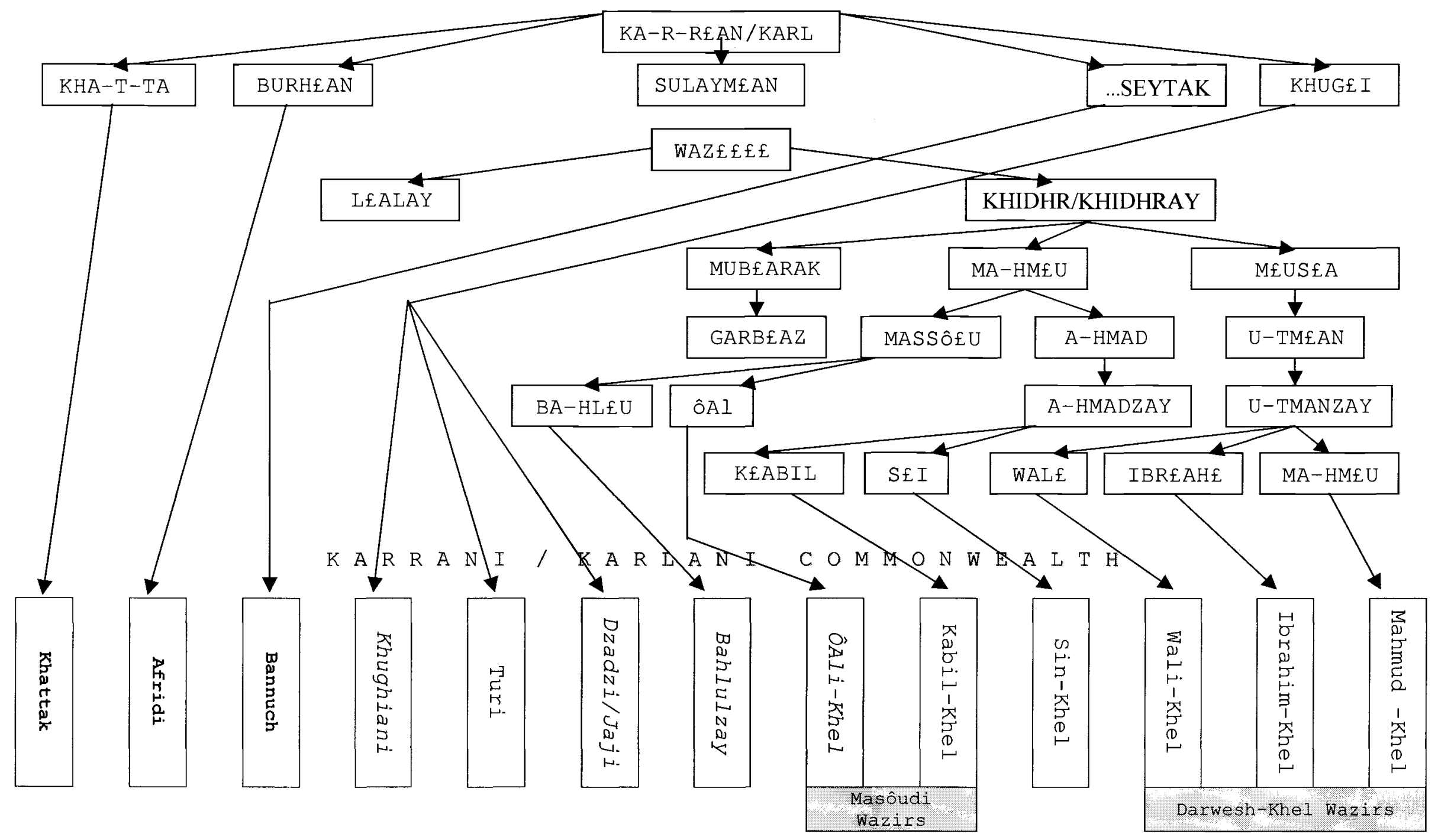


There is also a different view of the genealogy of Sulaymcan's descendants.

Chart 14. The Sulaymean lineage.

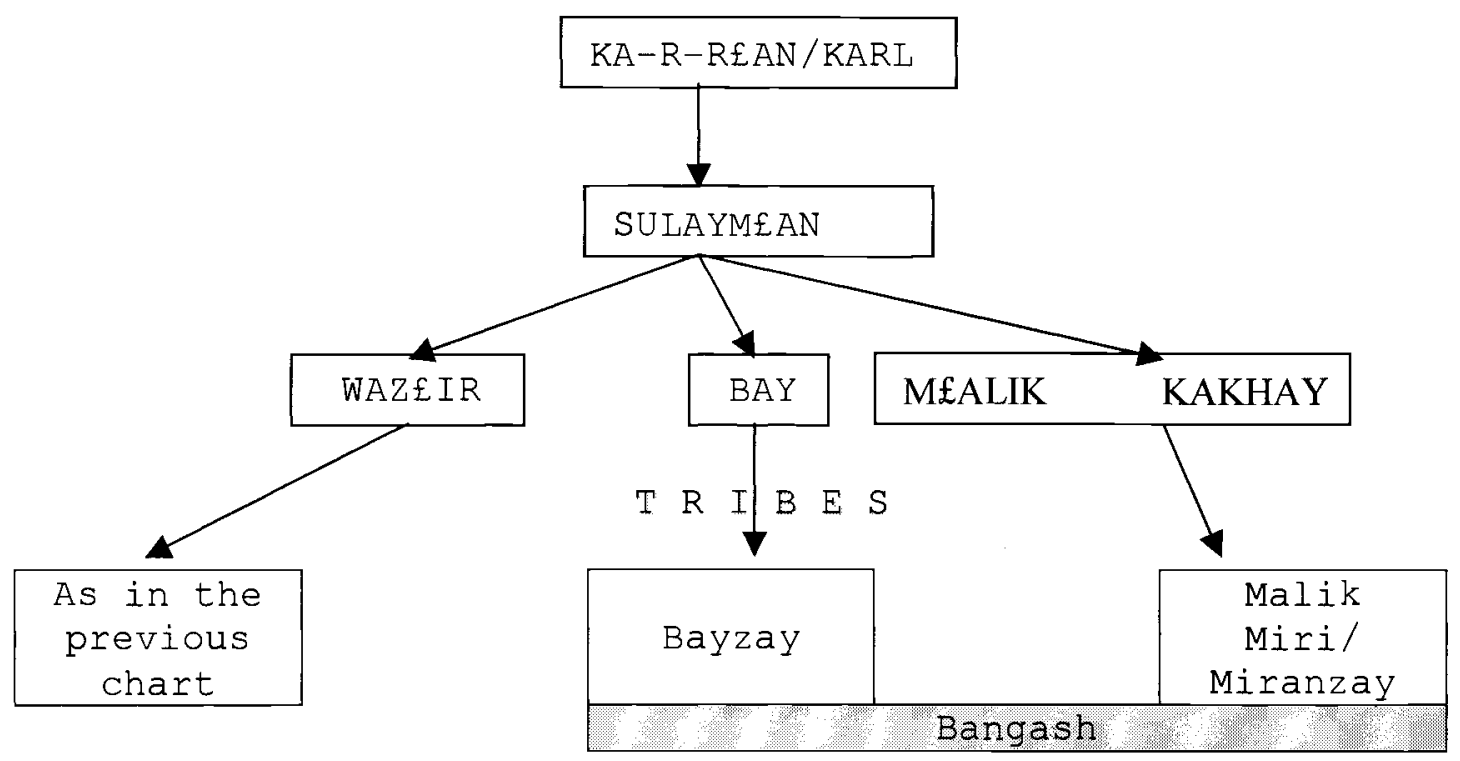

There is also a belief that the Wazirs, Daurs and Dilazaks have no relation to Qays and thus do not fit any segment of the Pashtun genealogy (Morgenstierne, 1961, pp.218-219; Muhammad Hayat Khan, 1981, Neamet Ullah, 1829-1836; Raverty, 1895, p.156; Robinson, 1935, pp.56, 58, 59, appendix 3; Romodin, 1980, pp.239-251; Rose, 1914, pp.204-205) 
Chart 15. The Durrani Commontealth.

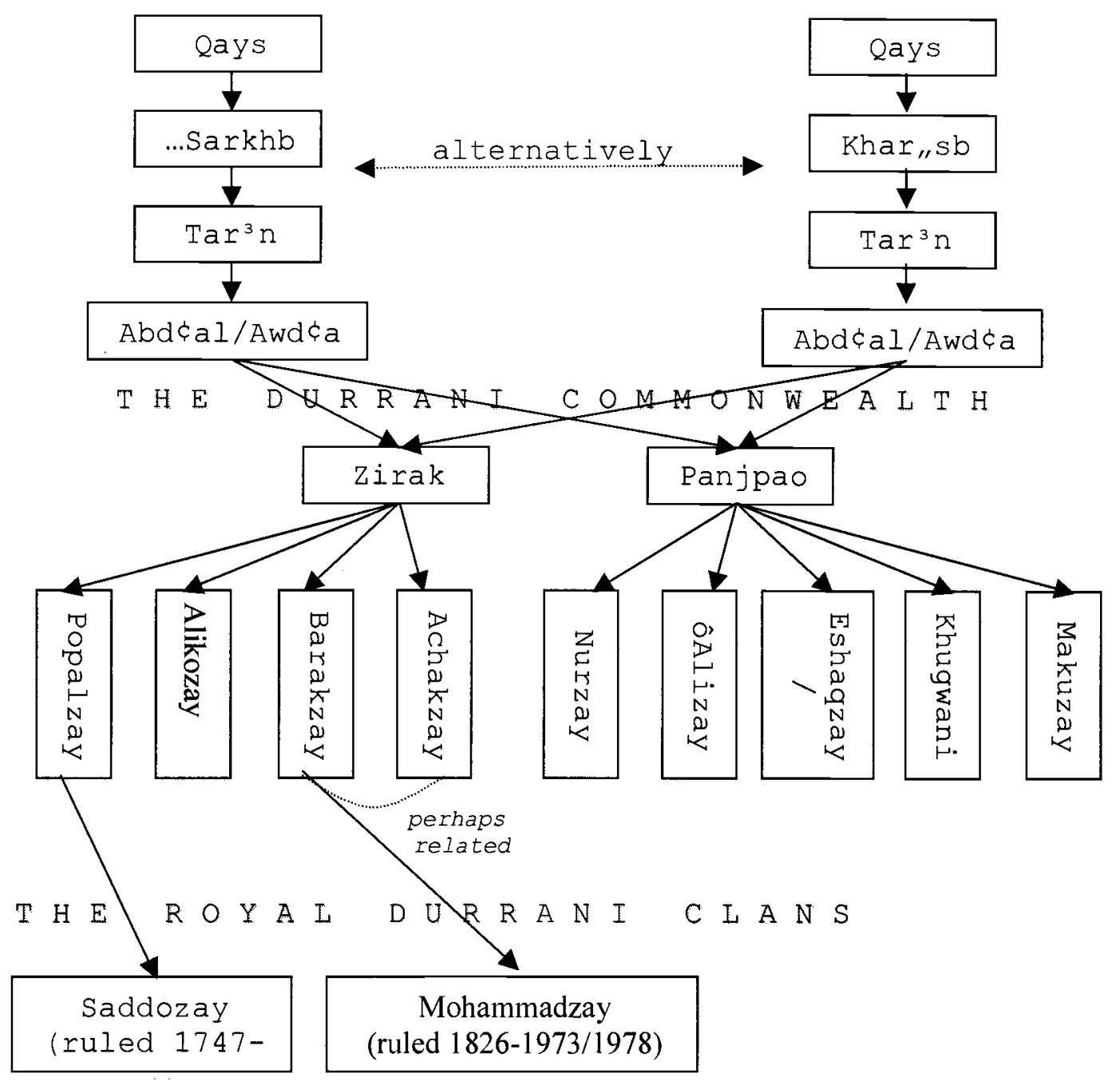


Chart 16. Geographical, demographic and linguistic data on some Pashtun tribes in Afghanistan*.

\begin{tabular}{|c|c|c|c|c|c|c|}
\hline $\begin{array}{l}\text { TRIBAL COMMONWEALTH } \\
\text { Or LINEAGE }\end{array}$ & ONISION & TriBes & 1.0 recarton & DIALECT & $\begin{array}{l}\text { MEMBERS } \\
\text { (THHOUSANDS) }\end{array}$ & OCCUPATION \\
\hline \multirow{8}{*}{ 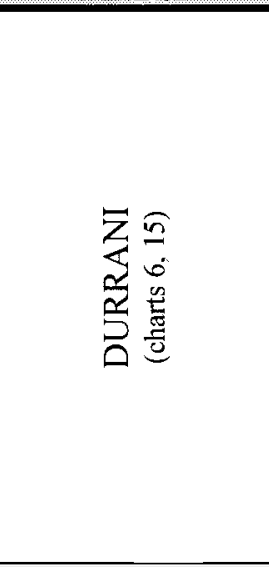 } & \multirow{5}{*}{ ZIRAK } & Popalzay & $\begin{array}{l}\mathrm{N} \text { and } \mathrm{E} \text { of Kandahar, } \mathrm{W} \text { of } \\
\text { the Helmand }\end{array}$ & $A$ & 400 & sedentary agriculturalists \\
\hline & & \multirow{2}{*}{ Alikozay } & E of Kandahar, & A & 400 & \multirow{2}{*}{ sedentary agriculturalists } \\
\hline & & & NE of the Helmand & $A$ & 400 & \\
\hline & & Barakzay & $\begin{array}{l}\text { SW of Qandahar } \\
\text { (Arghestan) }\end{array}$ & $A$ & 500 & sedentary agriculturalists \\
\hline & & Achakzay & Zamindawar, Kohdaman & $A$ & 100 & $\begin{array}{c}\text { sedentary agriculturalists, nomadic } \\
\text { pastoralists } \\
\end{array}$ \\
\hline & \multirow{3}{*}{ PANJPAO } & Nurzay & $\begin{array}{l}\text { SW and W Afghanistan } \\
\text { (Farah, Herat) }\end{array}$ & $A$ & 400 & nomadic pastoralists \\
\hline & & ôAlizay & Zamindawar, Helmand & $\mathrm{A}$ & 400 & sedentary agriculturalists \\
\hline & & $\begin{array}{c}\text { Eshaqzay/ } \\
\text { Sakzay }\end{array}$ & $\begin{array}{c}\text { W of Kandahar (Argandab), } \\
\text { Farah, Sistan }\end{array}$ & A & 400 & $\begin{array}{c}\text { sedentary agriculturalists and } \\
\text { pastoralists }\end{array}$ \\
\hline \multirow{11}{*}{ 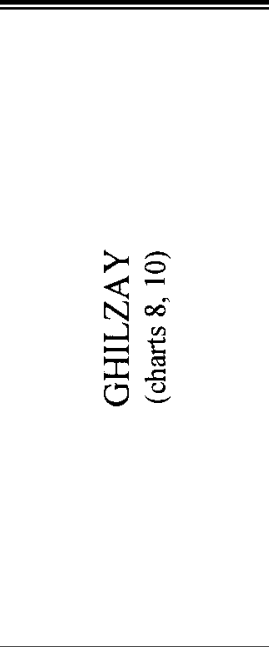 } & \multirow{4}{*}{ TURAN } & Hotak & $\begin{array}{c}\text { NE of Kandahar, Kalat, SE } \\
\text { of Ghazni }\end{array}$ & $A$ & 150 & sedentary agriculturalists \\
\hline & & Tokhi & Kalat, Tarnak, Arghandab, & A & 250 & sedentary agriculturalists \\
\hline & & Kharoti & Laghman, Paktia & $\mathrm{B}$ & $?$ & sedentary agriculturalists \\
\hline & & Nasar & Kohdaman (summer) & $\mathrm{B}$ & 40 & nomadic traders \\
\hline & \multirow{4}{*}{ AZIB } & $\begin{array}{l}\text { The Sulayman-Khel } \\
\text { Commonwealth }\end{array}$ & $\begin{array}{c}\text { Katawaz, S and SE of } \\
\text { Kabul }\end{array}$ & $\mathrm{B}$ & 500 & $\begin{array}{c}\text { nomadic traders (majority), } \\
\text { sedentary agriculturalists and } \\
\text { pastoralists } \\
\end{array}$ \\
\hline & & ÔAli Khel & Katawaz (Mokor), & $B$ & \multirow{2}{*}{140} & \multirow{2}{*}{ sedentary agriculturalists } \\
\hline & & OAll Knel & Paktiia & $\mathrm{A}$ & & \\
\hline & & Aka Khel & $\begin{array}{l}\text { throughout Afghanistan, } \\
\text { Kohdaman }\end{array}$ & $\mathrm{B}$ & 40 & nomadic camel breeders \\
\hline & \multirow{3}{*}{ MUSA } & Sahak tribes & S of Kabul & $\mathrm{B}$ & $?$ & sedentary agriculturalists \\
\hline & & Andar & Shilgar, Ghazni & $\mathrm{B}$ & 180 & sedentary agriculturalists \\
\hline & & $\begin{array}{c}\text { The Taraqi } \\
\text { Commonwealth }\end{array}$ & Katawaz (Mokor) & $\mathrm{B}$ & 220 & nomadic pastoralists \\
\hline
\end{tabular}




\begin{tabular}{|c|c|c|c|c|c|c|}
\hline \multirow{9}{*}{ 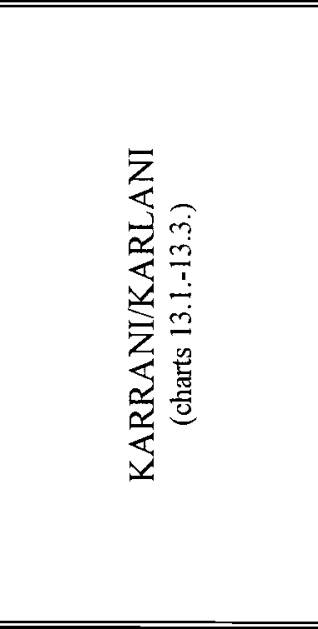 } & \multirow{6}{*}{ KAKHAY } & Afridi & Mashreqi & $\mathrm{C}$ & 60 & $\begin{array}{l}\text { sedentary agriculturalists and } \\
\text { pastoralists, charcoal-burners }\end{array}$ \\
\hline & & Mangal & Paktia & B & 200 & $\begin{array}{l}\text { sedentary pastoralists, wood } \\
\text { transporters and smugglers }\end{array}$ \\
\hline & & Jadran & Paktia & B & 180 & $\begin{array}{l}\text { sedentary pastoralists, wood- } \\
\text { cutters, seasonal labourers }\end{array}$ \\
\hline & & Khugiyani & Mashreqi & $\mathrm{C}$ & 120 & $\begin{array}{c}\text { sedentary agriculturalists and } \\
\text { pastoralists }\end{array}$ \\
\hline & & Turi & Paktia (Korm) & B & 40 & $\begin{array}{c}\text { sedentary agriculturalists and } \\
\text { pastoralists }\end{array}$ \\
\hline & & Jaji/Dzadzi & Paktia & $\begin{array}{l}\text { majority } C \\
\text { minority } B\end{array}$ & 220 & $\begin{array}{c}\text { sedentary agriculturalists and } \\
\text { pastoralists, wood transporters and } \\
\text { smugglers }\end{array}$ \\
\hline & None & Darwesh-Khel Wazirs & Paktiia, Frontier, Wardak & B & $?$ & sedentary agriculturalists \\
\hline & None & Masôud Wazirs & Paktiia, Frontier, Wardak & $\mathrm{B}$ & $?$ & sedentary agriculturalists \\
\hline & None & Wardak & Wardak & $\mathrm{B}$ & 200 & sedentary agriculturalists \\
\hline \multirow{3}{*}{$\begin{array}{c}\text { THE KHAR...SBEUN } \\
\text { LINEAGE } \\
\text { (chart 7) }\end{array}$} & $\begin{array}{c}\text { THE GHORIYAH KHEL } \\
\text { COMMONWEALTH }\end{array}$ & Mohmand & Mashreqi & $\mathrm{C}$ & 150 & $\begin{array}{c}\text { Sedentary pastoralists and } \\
\text { agriculturalists }\end{array}$ \\
\hline & None & Shinwari & Mashreqi & $\mathrm{C}$ & 100 & $\begin{array}{c}\text { sedentary agriculturalists and } \\
\text { pastoralists, silk-producers, } \\
\text { caravaneers } \\
\end{array}$ \\
\hline & None & Yusufzay & Farah & B & $?$ & $\begin{array}{c}\text { sedentary agriculturalists and } \\
\text { pastoralists } \\
\end{array}$ \\
\hline \multirow{3}{*}{$\begin{array}{l}\text { LODI } \\
\text { (chart 8) }\end{array}$} & \multirow{3}{*}{ None } & Lodi & $\begin{array}{c}\text { Winter Kunduz, Nangrahar; } \\
\text { summer Badakhshan, } \\
\text { Kabul }\end{array}$ & $\mathrm{B}$ & $?$ & nomadic pastoralists \\
\hline & & Niyazi & $\begin{array}{c}\text { Winter Kandahar; summer } \\
\text { Ghazni }\end{array}$ & B & $?$ & nomadic pastoralists \\
\hline & & Dotani & $\begin{array}{c}\text { Winter Kandahar; summer } \\
\text { Ghazni }\end{array}$ & B & $?$ & nomadic pastoralists \\
\hline \multirow{2}{*}{$\begin{array}{l}\text { THE GHURGU...ST } \\
\text { LINE (chart 12) }\end{array}$} & PANI & Safi & Kunar, Kuhestan & $\mathrm{C} / \mathrm{B}$ & 220 & $\begin{array}{l}\text { sedentary agriculturalists and } \\
\text { pastoralists, apiculturalists }\end{array}$ \\
\hline & None & Kakar & E and SW of Kandahar & B & 150 & $\begin{array}{c}\text { sedentary agriculturalists and } \\
\text { pastoralists, caravaneers }\end{array}$ \\
\hline $\begin{array}{l}\text { THE ...SARKHBEUN } \\
\text { LINEAGE (chart 6) }\end{array}$ & None & Barets & S of Kandahar & A & 30 & sedentary agriculturalists \\
\hline
\end{tabular}




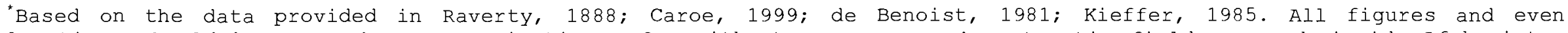

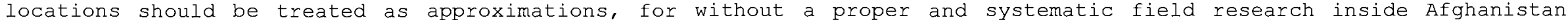
exact data reflecting the quickly changing reality on the ground cannot be obtained.

For dialect distinction in the Pashto language see the section "Major Languages of Afghanistan and Their Literary Traditions". 
In order to be a Pashtun it is not sufficient to belong to a Pashtun tribe; one has

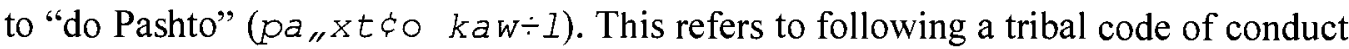
known as Pashtunwali" ${ }^{51}$. For the definition of Pashtun identity the practice of "doing Pashto" is explicitly superordinate to speaking the Pashto language (pa „xt $c 0$ wa $y \div 1)$. Therefore, only those who live according to the norms of Pashtunwali are considered true Pashtuns, while possession of the Pashto language as somebody's native tongue is not considered as a sufficient criterion for being Pashtun.

Sometimes Pashtunwali is regarded as the code of honour (Pstrusińska, 1983, p.92); however, this is only partly true. The code of honour is an integral part of Pashtunwali, which also includes moral values, social institutions, military virtues, kinship structures, tribal genealogy, customary law and Islamic religiosity ${ }^{52}$. In general Pashtunwali is the combination of traditions, which, as the Pashtuns themselves think, distinguish them from all other peoples (Rzehak, 1989, p.58; Rzehak and Griunberg, 1992, p.184).

The principles of Pashtunwali constitute the pillars of the edifice of tribal life. It has been argued by Willi Steul, the author of the only monograph on Pashtunwali, that the cornerstone of Pashtunwali is the concept of ghayratman (a man of honour, hero-warrior). Although the notion of ghayratman is connected with general military bravery and the use of force only Pashtuns who display some altruistic qualities are accorded this title. Thus, the true ghayratman is expected to defend and actively support the interests and honour of his family, village, clan, tribe, nation

\footnotetext{
${ }^{51}$ In the original Pashto it is $p \div 2 x t \div n w$ calay. I shall, however, use this term in its anglicised form as it is always referred to in anthropological literature.

52 Pashtun social institutions are discussed in the section "The Social Structure of Afghan Society" and genealogy is described above.
} 
and above all women ${ }^{53}$ (Steul, 1981, pp.172-177). Observance of the rules of ghayratman conduct involves meeting two sets of behavioural expectations focused on the preservation of honour. The first one deals with nang (ah) (honour, reputation), i.e. community oriented actions: ncamcus (honour, dignity) - the defence of women and territory and $n \div n a w \xi a t a h$ (asking for forgiveness or help) the support and defence of those who are unable to defend themselves, usually clients, as well as the mechanism for settling blood disputes; the second one is tcurah (bravery but also sword) which implies the Pashtun's personal honour. Communal interests are considered more important than the personal ones (Janata and Hassas, 1975, pp.85-87; Rzehak and Griunberg, 1992, pp.188-194; Steul, 1981, pp.137-147, 151-153). Charles Lindholm suggests that there are more pillars of Pashtunwali, namely revenge/compensation - literally "exchange" (bada I), hospitality (mধelmasteyka) and $n \div$ nawcatah, which he interprets as refuge ${ }^{54}$ (Lindholm, 1982, p.211). He insists that the principles of Pashtunwali serve to mask or reconcile the realities of the social structure. Revenge unites men and gives the minimal form necessary for social life while equality and respect rituals enact the two potentially hostile members of the segmentary system (Lindholm, 1982, pp.237-238).

It appears that all other rules are derived from the above-mentioned concepts. They serve to meet the challenges of everyday life and provide specific guidelines to those who live according to Pashtunwali. In his description of Pashtunwali the Afghan

${ }^{53}$ M.G. Aslanov offers the following translation of the word ghayrat: sense of dignity (chuvstvo sobstvennogo dostoinstva), self-respect (samouvazhenie), pride (gordost'), ambition (samolyubie); zeal (rvenie), eagerness (userdie), ardour (pyl); valour (doblest'), courage (muzhestvo) bravery (smelost'); indignation (negodovanie, vozmuschenie); modesty (skromnost') (Aslanov, 1966, pp.621-622).

${ }^{54}$ In Pashto there is a special expression for providing a refuge (pan $\xi a \quad k a w \div 1$ ). Pashtuns cannot refuse a request for refuge because it could be interpreted as a sign of weakness (Rzehak and Griunberg, 1992, p.194); thus their personal honour will be undermined. 
codifier of the norms of tribal life Qeycam al- $D^{3} n$ Kh\&adem mentions the following foundations of the Pashtuns' way of $\operatorname{life}^{55}$ : ethics of war, i.e. death punishment for deserters, obligatory removal of the bodies of killed fighters, fighting until victory or death, preference for the sudden attack at night (dca--rah), women fighting alongside with men; taking of hostages or property for an unpaid debt (b (a) ramtah); respect of elders; holy war (jehcad); tribal assembly (jergah); truce/laying the stone (te,gah); promise and faithfulness (ôahd $a w$ wa $\left.f^{3} a\right)$; truthfulness $\left({ }^{3} m \xi a n d \xi a r^{3}\right)$; strength of determination (klaka

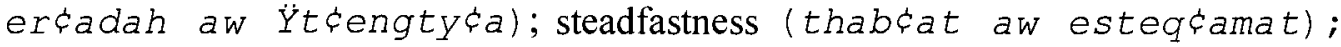
ethnic pride $\left(m e l l^{3}\right.$ ghorkur); self-respect ( $d \div d z \xi a n$ ôezzat); courage

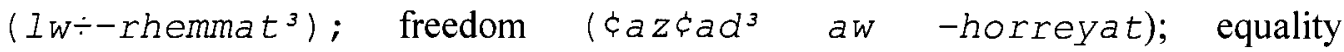
(moskawkat); defence of the guest ( $p \div m \div 1$ mah ghayrat); safe escort (badragah); patriotism $\left(d \div\right.$ wa-tan $\left.m^{3} n a h\right)$; national independence (mel $I^{3}$ esteqlial); honesty (deykanat); chastity (płak ${ }^{3}$ aw ôffat); unity (ettefaq); simplicity (sładag $\left.{ }^{3}\right)$; respect of national traditions; attention to the role of women as housekeepers; upbringing of children in accordance with national traditions; love for national games; telling the truth (re „xteyca); mutual help (mrastah); aid to the poor (baspanah); local militia (ch ${ }^{3} g h a h$ (literally "cry", "call")); rivalry/competition ( gi und ${ }^{3}$ (literally "partisanship"); exchange of hostages for securing the truce (yarghama I); fidelity in marriage; celibacy of widows ( $k$ kunt $\xi u n)$; penal code (Kh $\xi a d e m, 1952$ ).

Thus, according to Pashtunwali, Pashtun society is governed by the following principles:

\footnotetext{
${ }^{55}$ As it also is the case with the main rules of Pashtunwali the words designating principles derived from these main rules often have a double meaning.
} 
1. Every Pashtun has sovereign, unassailable rights, which can be restricted only by his leader. Pashtuns follow their leaders only on a voluntary basis.

2. All facets of society and Pashtun society as a whole have sovereign and unassailable rights.

3. Life is hard and the world hostile. Both the individual and all tribal facets are under constant threat from outside. Therefore defence of both is essential.

4. The individual and the society are responsible for each other. The interests of both have equal significance.

5. The continued existence, sovereignty and honour of the individual and tribal facets are guaranteed by land ownership.

6. Women guarantee further existence of the Pashtuns but they are of lower social rank than men. Women should be protected against physical attacks. Sexual relations are possible only within wedlock. Violation of the exclusive sexual rights of the husband constitutes an attack on his personal honour (Steul, 1981, pp.309-310).

Defence of these principles is the right and obligation of every Pashtun. Since in traditional Pashtun society there are no law-enforcement agencies, self-defence is the sole responsibility of an offended man. In the case of a clear violation of the individual's rights ( $t$ ceray) the tribal council (jergah) gives the offended the right to demand revenge and withdraws its support from the offender.

There are some apparent contradictions between Pashtunwali and the rules of the "sar ${ }^{3}$ ot. Thus punishments prescribed by the Koran are not applied. Women are disinherited of real property and in marriage lose rights to their natal lineages ${ }^{56}$.

${ }^{56}$ L. Rzehak and A.L. Griunberg are of different opinion (Rzehak and Griunberg, 1992, p.191). 
Divorce is virtually impossible, marriage is absolutely binding and inheritance of widows is common (Anderson, 1984, p.276). The general view of women as perpetuators of the Pashtun ethnos is sometimes connected with the pre-Islamic belief in Mother Earth (Steul, 1981, p.141; Janata and Hassas, 1975, p.86). Besides these obvious legal differences the ethos of Pashtunwali is also quite different from that of the "sar ${ }^{3} a t$. While the "shar ôat focuses on precise punishment of the wrongdoers in communal interests, Pashtunwali deals with the revenge of violations of personal honour.

Thus, the focus of Pashtunwali is on matters of honour, either personal or collective. This concept of honour goes beyond the notion of personal dignity. In a highly competitive segmentary society honour becomes the symbol of social prestige and political power; defence of honour can thus be understood as a political action aimed at maintaining or improving individual or collective status.

The all-embracing importance of personal and communal honour in Pashtunwali sometimes obscures the true significance of Islam in the system of Pashtun values. Thus Louis Dupree describes Afghan society as characterised by "religious non-literacy" (Dupree, 1980, pp.95-112) and Leon Poullada denies the genuine Islamic character of the tribal revolt against King Am\&an Al calh (Amanulla) in 1929 (Poullada, 1973, p.171). Unlike the above-mentioned authors, Jon W. Anderson argues that for Pashtuns tribalism (in a sense of belonging to a tribe) is a primary manifestation of their identity as Muslims (Anderson, 1984, p.266). For Pashtuns being Muslim is inseparable from their heritage and tribal genealogy. They deny having any pre-Islamic past or history of conversion. According to common belief, Qays, the ancestor of all Afghans, went to Mecca as soon as he learnt of the mission of the Prophet Mo-hammad. In Mecca he received Islam directly from the 
Prophet who called him ôAbd al-Ra, $\mathrm{s}^{3} \mathrm{~d}$. Thus, the Pashtuns make a claim to an exemplary Islam and an exemplary possession of Islam. The Pashtuns assert that Qays had a kind of companionship with the Prophet Mu-hammad similar to that of the Prophet's closest associates. Since there were no Pashtuns before Qays who embraced Islam so soon after it had been revealed, the Pashtuns consider themselves as members of an exclusively Muslim people ( $q a w m$ ). Thus qawm, i.e. the community of all Pashtuns and their way of life, is regarded as a kind of Islamic tradition (sunnat) as well as the means of mediation of Islam to the Pashtuns. Therefore, the Pashtuns reason that what they do must be in complete accordance with Islam since it is not possible to be more Muslim than they are. Thus it is assumed that to be a Pashtun is to be a Muslim, while the reverse is not true. They think that only the Sayyeds (but not other Arabs), who are respected as the Prophet's own qawm, are superior to them. Moreover, Pashtunwali is considered as a more genuine form of religion in comparison with both normative and mystical Islam. Other people need the transmission of Islam through "sar ${ }^{3}$ ot and Sufism more than the Pashtuns who are "already" Muslims. Thus tribalism becomes a form of salvation and all attempts to undermine the tribal way of life are compared to repeated failures of revelation prior to the Prophet Mo-hammad and, as many Pashtuns think, the work of Satan. These concepts are taken for granted and, therefore, do not require an explanation. This claim to a unique position of the Pashtuns within the wider world of Islam may be considered as an identification of "the way of the Pashtuns" with Islam. Islam thus becomes a part of Pashtun ethnic identity. The complete confidence in the Islamic character of the Pashtunness constricts the role of religious groups and explains the continuation of Pashtun customs, which from the outsider's point of view contain non-Islamic elements. The mediation of Islam through Qays is not in agreement with 
conventional types of transmission through "sar ${ }^{3}$ ôt and Sufism. Some Pashtuns are aware of the contradictions between Pashtunwali and Islamic norms. This conflict is dissolved by keeping Pashtunwali, "sar ${ }^{3}$ ôt and Sufism apart, in separate contexts and as alternatives to each other (Ahmed, 1984, pp.311-313; Anderson, 1984, pp.274-277, 280-283; Barth, 1981[2], p. 105).

Sometimes this view of the unique nature of the Pashtuns' Islam can reach extreme manifestations. The modern Afghan author Sayyed Ras $\measuredangle u l$ Ras $\$ a$ writes about his mother who travelled to Delhi from her native village. Since nobody spoke Pashto in the Indian capital she decided that there were no Muslims in Delhi. For her being a Muslim entailed obligatory command of Pashto ${ }^{57}$.

\subsubsection{TAJIKS.}

Approximately 3,500,000 Dari-speaking ${ }^{58}$ Tajiks of Afghanistan live predominantly in the north of the country, concentrating mainly in the northeast where they refer to themselves by the valley or region where they live. Those living in the areas dominated by other ethnic groups refer to themselves as Tajik. The bulk of the Tajiks are agriculturalists working on their ancestral land allotments, which are never redistributed. In some areas the land is owned by big landlords who have their fields worked by tenant farmers. Tajiks are non-tribal people and predominantly - Hana ${ }^{3}$ Sunni.

The term " $t$ cjek" that in its modern meaning denotes a people in Central

\footnotetext{
${ }^{57}$ Sayyed Rascul Rasca, $D \div$ Kho,s-hלal Khcan Eslcam ${ }^{3}$ Kerdcar, in Nangycalay Pa»xtcun/Muhtammem: Mco-hammad Akbar Moôtamad, K६abol, 1345 A.H./1966 A.D., pp.132-139, quoted in Pelevin, 1993, p.228.

${ }^{58}$ The Dari of Afghan Badakhshan is closer to the Tajik language rather than the more or less normative Dari, thus being a classical example of the linguistic continuum. For more details on the Dari language see the section "Major Languages of Afghanistan and their Literary Traditions".
} 
Asia and Afghanistan ${ }^{59}$ has a complicated history full of surprises ${ }^{60}$. Its proto-form

first appeared in Iranian languages as well as in Aramaic and Armenian as the

ethnonym of all Arabs and in the end the appellation of all Muslims. It was derived

from the name of the Arab tribe - Tayy $^{3}$ é (or perhaps its adjective $-t_{a}{ }^{3}$ ), which

domain bordered Chart 17 . DARI-SPEAKING ETHNIC GROUPS*.

\begin{tabular}{|c|c|c|c|c|c|}
\hline DIALEECT & 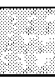 & IOCATION & ETHNIC GROUP & $\begin{array}{c}\text { LOCAI NAME OF } \\
\text { DIALECT }\end{array}$ & TRATISS \\
\hline \multirow{14}{*}{ A } & 1 . & Kabul city & Tajik & $\mathrm{K} \dot{\mathrm{ab} o l^{3}}$ & $\begin{array}{c}\text { Urban, Indian } \\
\text { elements }\end{array}$ \\
\hline & \multirow{4}{*}{2 . } & $\begin{array}{l}\text { Panjsher } \\
\text { valley }\end{array}$ & $\begin{array}{c}\text { (Panjsheri) } \\
\text { Tajiks }\end{array}$ & $\operatorname{Panj}_{\text {"s ser }}{ }^{3}$ & $\begin{array}{l}\text { Rural, Indian } \\
\text { elements }\end{array}$ \\
\hline & & $\begin{array}{l}\text { Salang } \\
\text { valley }\end{array}$ & Tajik & Fcars ${ }^{3}$ & Rural \\
\hline & & $\begin{array}{l}\text { Ghorband } \\
\text { valley }\end{array}$ & Tajik & Ghorbandi & Rural \\
\hline & & Kohestan & Tajik & Kohestani & Rural \\
\hline & \multirow[t]{2}{*}{3.} & $\begin{array}{l}\text { Logar } \\
\text { (Kolangar, } \\
\text { Dushanbah, } \\
\text { Patkaw-e } \\
\text { Roghani, } \\
\text { Baraki- } \\
\text { Rajan) }\end{array}$ & Tajik & F cars ${ }^{3}$ & Rural \\
\hline & & $\begin{array}{l}\text { Chark-e } \\
\text { Logar }\end{array}$ & Tajik & $\operatorname{Cark}^{3}$ & Rural \\
\hline & \multirow{4}{*}{4.} & $\begin{array}{l}\text { Laghman } \\
\text { valley }\end{array}$ & Laghmani & Laghm $\operatorname{an}^{3}$ & $\begin{array}{l}\text { Rural, with } \\
\text { deep Pashto } \\
\text { contamination }\end{array}$ \\
\hline & & $\begin{array}{l}\text { Sorkrod } \\
\text { (Nangrahar) }\end{array}$ & Tajik & Fcars ${ }^{3}$ & Rural \\
\hline & & $\begin{array}{l}\text { Kandibag } \\
\text { (Nangrahar) }\end{array}$ & Kandibaghi & $\operatorname{Kand}^{3} \mathrm{~b} \operatorname{agh}^{3}$ & Rural \\
\hline & & $\begin{array}{l}\text { Urgun } \\
\text { (Paktia) }\end{array}$ & Urgun/Pormul & Fלars ${ }^{3} /$ Porm ul $^{3}$ & Rural \\
\hline & 5. & Badakhshan & $\begin{array}{c}\text { (Badakhshi) } \\
\text { Tajiks }\end{array}$ & Badakh, $s^{3}$ & $\begin{array}{c}\text { Rural, Tajik } \\
\text { elements }\end{array}$ \\
\hline & 6. & $\begin{array}{l}\text { Mazar-e } \\
\text { Sharif city }\end{array}$ & Tajik & Mazłar ${ }^{3}$ & $\begin{array}{c}\text { Urban, Tajik } \\
\text { elements }\end{array}$ \\
\hline & 7. & Qataghan & Tajik & Qataghan ${ }^{3}$ & $\begin{array}{c}\text { Rural, Tajik } \\
\text { and Turkic } \\
\text { elements } \\
\end{array}$ \\
\hline \multirow[t]{2}{*}{$\mathrm{B}$} & & Herat city & Tajik & Hercat ${ }^{3}$ & $\begin{array}{c}\text { Urban, } \\
\text { Khorasani } \\
\text { elements }\end{array}$ \\
\hline & & $\begin{array}{l}\text { West of } \\
\text { Herat }\end{array}$ & Taymuri & Fcars ${ }^{3}$ & $\begin{array}{c}\text { Rural, } \\
\text { Khorasani } \\
\text { elements }\end{array}$ \\
\hline
\end{tabular}

${ }^{59}$ Many Afghan Dari-speakers started to call themselves Tajiks only a few decades ago.

${ }^{60}$ There is a great number of rather bizarre, mainly popular, etymologies of the word $t \notin a j e k$, which are beyond academic discussion and therefore should not be dealt with here. 


\begin{tabular}{|c|c|c|c|c|}
\hline & $\begin{array}{l}\text { North of } \\
\text { Herat }\end{array}$ & Jamshidi & F\&ars ${ }^{3}$ & Rural, \\
\hline & $\begin{array}{l}\text { Qalôa-ye } \\
\text { Now }\end{array}$ & Hazara & $F \notin a r s^{3}$ & Rural \\
\hline & Ghor & Aymaq & Aym $\dot{\text { \&aq }}^{3}$ & $\begin{array}{c}\text { Rural, Turko- } \\
\text { Mongolian } \\
\text { elements }\end{array}$ \\
\hline & Ghor & Firozkohi & $\mathrm{E}^{3} \mathrm{rcuzkcoh^{3 }}$ & Rural \\
\hline & Ghor & Taymani & Tayman $^{3}$ & Rural \\
\hline & Farah city & Tajik & Farcah ${ }^{3}$ & $\begin{array}{c}\text { Urban, } \\
\text { Khorasani } \\
\text { elements }\end{array}$ \\
\hline & $\begin{array}{l}\text { Kandahar } \\
\text { city }\end{array}$ & Tajik & F\&ars ${ }^{3}$ & Urban \\
\hline C & $\begin{array}{l}\text { Kang and } \\
\text { the region } \\
\text { of } \\
\text { Ebrahimabad }\end{array}$ & Sistani & $\mathrm{S}^{3} \operatorname{sta}^{1} \mathrm{n}^{3}$ & $\begin{array}{c}\text { Rural, } \\
\text { Sistani and } \\
\text { Baluchi } \\
\text { elements } \\
\end{array}$ \\
\hline D & Hazarajat & Hazara & $\mathrm{Haz}_{\text {\&arag }}{ }^{3}$ & $\begin{array}{c}\text { Rural Mongol } \\
\text { elements }\end{array}$ \\
\hline
\end{tabular}

Based on Keiffer, 1985, p.510 
the Sasanian Empire. However, the New Persian word tcajek cannot be traced back to the Middle Persian $t \Varangle a z^{3} g$, which developed into the New Persian $t$ ca $z^{3}$, still meaning "Arab". The form tcajek ultimately goes back to a Parthian equivalent of this Middle Persian word, which found its way into the Sogdian language.

When from the end of $7^{\text {th }}$ century on the Sogdian territories were raided and eventually occupied by Muslim armies the warriors of Islam were not exclusively Arabs but consisted mainly of Persian converts, so for the Sogdians they were the Tajiks, viz. those associated with Arabs and Islam. Consequently, especially among Central Asian Turks, the term came to mean speakers of Persian and later on settled and urban people in general. The appearance of the word $t \xi a j e k$ in the Manichean context signifies that Tajiks were not only Muslims but all people speaking the language of Muslims, i.e. New Persian in the case of Central Asia (Bartol'd, 1963, pp.455-457; Sundermann, 1993, pp.163-171). However, the later use of the term "tcajek" has even broader implications - thus, not only those who speak Iranian languages like some sedentary ethnic groups in the Iranian province of Fars speaking South-West Persian dialects but even some Dards in Afghanistan and Turkic groups in Central Asia, that no longer follow the tribal way of life, call themselves Tajiks (Griunberg, Steblin-Kamenskii, 1989, p.36) and in the case of Turkic areas of Central Asia they might be considered as such by their neighbours (Zarubin, 1925, p.7) ${ }^{61}$. Thus, the differentiation between Tajiks and non-Tajiks reflects not only and not so much linguistic differences as distinction between the nomads and the sedentary as well as between tribal and non-tribal communities.

${ }^{61}$ This term may have the same meaning even beyond the world of Iranian culture, thus the Trans-Caucasian Armenians call the Turks who live among them Tajiks (Zarubin, 1925, p.7). 


\subsubsection{PERSIANS.}

Often mistakenly referred to as Tajik, from whom they are distinguished by their language, which is close to the Khorasani dialects of Persian rather than "normative" Dari, as well as by their Imami Shiite religion. Approximately 600,000 of them live along the Afghan-Iranian border or in Herat, Kandahar and Ghazni. Locally they are known as Persian-speakers ( $f \xi a r S^{3} w \xi a n$, with regional variations $p \xi a r S^{3} w \xi a n$ or $\left.p \xi a r s^{3} b \xi a n\right)$. Socially they differ little from the sedentary agriculturalist Tajiks.

\subsubsection{HAZARA.}

Approximately $1,000,000^{62}$ Hazara people are concentrated in the Central Highland of Afghanistan in the area known as Hazarajat, which stretches from Kabul to Herat; there are also Hazara resident in Kabul and other urban centres as well as smaller pockets in the north of the country. Outside Afghanistan Hazara can be found in Iran, Pakistan, Turkmenistan and Tajikistan. There is no agreement whether to consider their language, which possesses many unstudied dialects, as a dialect of Dari or an independent language (Efimov, 1997, p.155; Farhadi, 1975).

Hazara are tribal people with their social structure based on kinship. The majority of them are Imami Shiites, but there are also Ismaili and Hanafi Sunni groups among them.

The ancestors of Hazara may have arrived to the area with the Mongol armies within the period of 1229-1447. Their ethnic name which might be derived from Persian/Dari hazcar - thousand (the strength of a unit in the Mongol army) may

\footnotetext{
${ }^{62}$ Like it is the case with many other ethnic groups in Afghanistan there is no consensus on their numerical strength, thus estimations for Hazara range from $1,000,000$ to $1,800,000$ people.
} 
serve a prove this assumption, though it might be nothing but an attempt in popular etymology. The language of Hazara is heavily contaminated by Turko-Mongolian elements and there are evidences that in the $19^{\text {th }}$ century there were still Mongolianspeaking Hazara ${ }^{63}$.

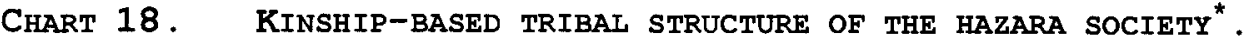

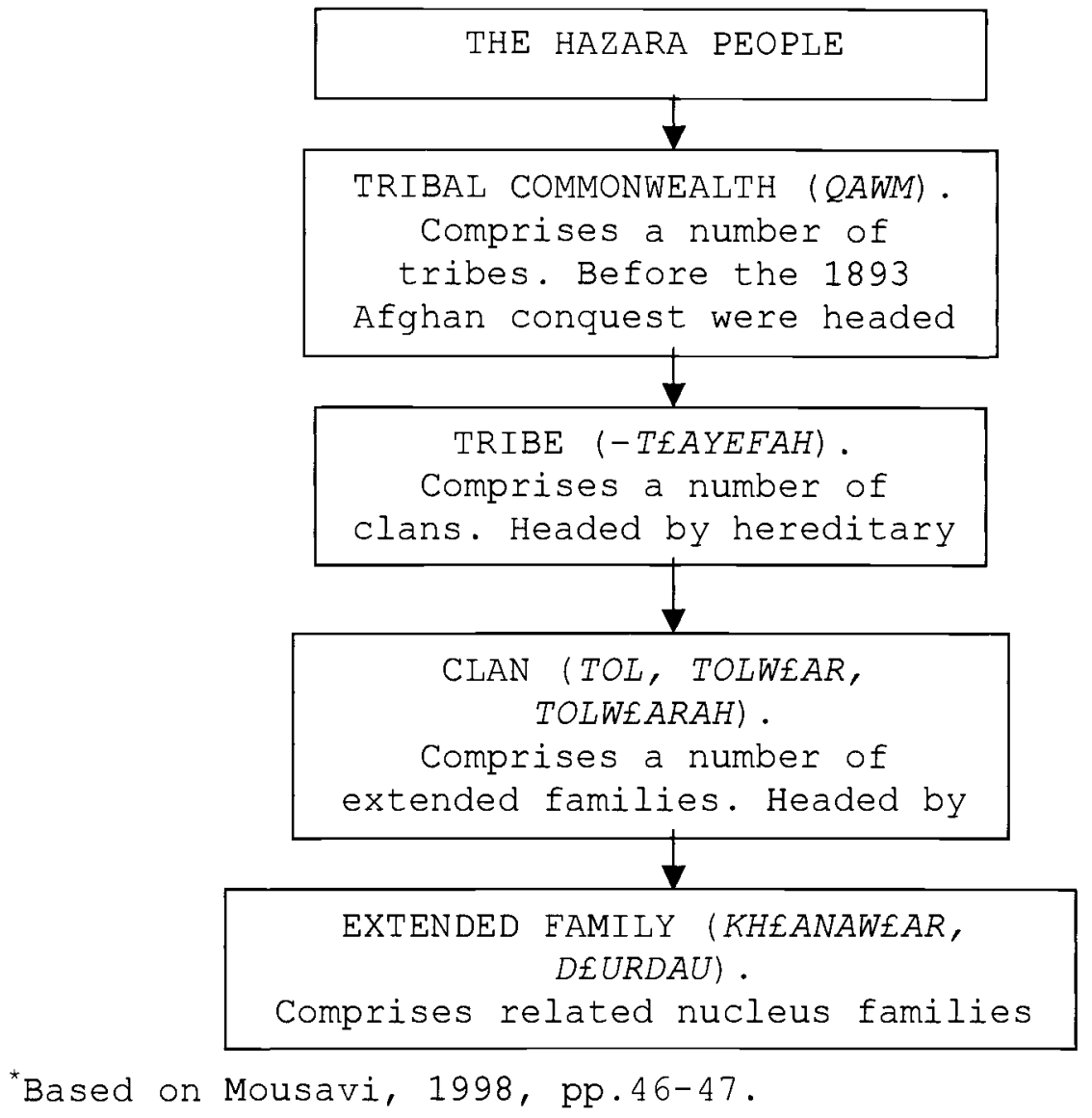

Prior to the gradual subjugation of Hazarajat by Emir ôAbd al-Ra-hm in 1880-1990 followed by sporadic uprisings of the local population the Hazara were virtually independent. However, they did not form any state structures thus perpetrating the tribal way of life where the political landscape was dominated by the hereditary heads of tribal commonwealths. The uprising was dealt with brutally and

${ }^{63}$ It is interesting that occasionally Hazara refer to a discourteous person as non-Mongolian.

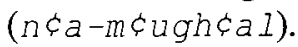


many heads of tribal commonwealths were removed and often killed. As a means of controlling his newly acquired subjects Emir ôAbd al-Ra-hm६an granted to the Ghilzay Pashtun nomads some grazing rights in Hazarajat; this move generated a century-old ethnic and economic conflict in the area.

Because of their predominantly non-Sunni religious background and to a certain degree mild Mongoloid appearance the Hazara were discriminated by the government and frowned upon by ordinary people. Many of them moved as menial workers to the cities and settled there, with some families rising to the "middle class" level.

Since the coming of the Par „cam faction of the PDPA to power the position of the Kabuli Hazara improved. Members of the Hazara community were appointed Prime Minister and Deputy Prime Minister and in 1987 the Hazara were able to establish The Central Assembly of the Hazara People (Jergah-e sar casar ${ }^{3}-y e$ mellat-e hazcarah) the move that put them on equal footing with the Pashtuns who had been the only ethnic group allowed to form this instrument of selfgovernment (jergah). Moreover, 1989 saw the opening of the Centre for the Harmonization of Hazara National Affairs (Markaz-e ensej jam-e ôomcur-e mellat-e hazcarah) and the declaration of Hazara's right of selfdetermination.

While more educated urban Hazara exploited the new opportunities presented to them by the PDPA government, rural Hazara took a different stand. By rejecting these opportunities they were able to take advantage of the breakdown of the old system and instability of the new regime in order to renegotiate their position in the Afghan society. Hazara resistance began in Darra-ye Suf ten months after the April 1978 coup d'etat and very soon the entire Hazarajat was recovered from the 
governmental control by the Council of Concord (...Scurca-ye Ettefcaq) headed by the religious leader $\mathrm{Beh}^{3}{ }, \mathrm{st} \mathrm{t}^{3}$ and with its main power-base among tribal aristocracy. However, by 1983 the situation deteriorated due to the emergence of Iranbacked Hazara parties, which were more preoccupied with fighting against each other rather than waging the jeh ${ }^{2} d$. This internal conflict led to the destruction of socioeconomic infrastructure of the region as well as killing and displacement of a considerable number of civilians. As a result of these developments Hazara turned into one of the most politicised and active ethnic groups in Afghanistan, which succeeded in reasserting its autonomy by going as far as expelling Pashtuns from their land. The social fabric of the society was also affected with the tribal leaders losing their dominance in favour of the moj $\operatorname{cahed}^{3} n$ commanders. The situation more or less stabilised with the establishment of -Hezb-e Wa-hdat-e Eslcam ${ }^{3}$ (Party of the Islamic Unity) in 1989 (Mousavi, 1998, 176-186, Roy, 1985, pp.142-144). However, after the moj ahed $^{3} n$ victory in 1992 -Hezb-e Wa-hdat plunged into the new wave of the civil war forming and breaking alliances with other militarypolitical groups. After the emergence of the -Tialebcan it became one of the founders of the anti-Taliban Supreme Defence Council (...S łurła-ye ôa ${ }^{3}-y e$ def̧ấ).

\subsubsection{CHAR AYMAQ.}

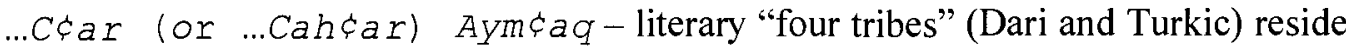
in north-western Afghanistan, north-eastern Iran and southern Turkmenistan. All of them speak Dari dialects incorporating much Turkic vocabulary. They are mainly agriculturalists and transhumants. 


\section{Chart 19. The Char Aymad tribal groups*.}

\begin{tabular}{|c|c|c|c|c|}
\hline $\begin{array}{l}\text { TRIBAL } \\
\text { NAME }\end{array}$ & ORIGIN & $\begin{array}{c}\text { MEMBERS } \\
\text { (THOUSANDS) }\end{array}$ & LOCATION & OCCUPATION \\
\hline JAMSHEDI & $\begin{array}{l}\text { Legends derive } \\
\text { their origin } \\
\text { from King } \\
\text { Jam,sed of the } \\
\text {...scah-Ncamah and } \\
\text { locate their } \\
\text { homeland in } \\
\text { Seistan. }\end{array}$ & $170-180$ & $\begin{array}{l}\text { North-western } \\
\text { parts of Herat and } \\
\text { Badghis (districts } \\
\text { Kushk and Gulran) } \\
\text { and between the } \\
\text { Kushka and Herirud } \\
\text { rivers. } \\
\quad \text { Also in } \\
\text { Qattagan and Mary } \\
\text { district of } \\
\text { Turkmenistan. }\end{array}$ & Agriculturalists \\
\hline TAYMANI & $\begin{array}{l}\text { Unknown, } \\
\text { possible mixture } \\
\text { of Turkic and } \\
\text { Pashtun } \\
\text { elements. }\end{array}$ & 120 & $\begin{array}{l}\text { South-east of the } \\
\text { city of Heart in } \\
\text { the upper valley } \\
\text { of the Farhrud, } \\
\text { district } A b \text {, in } \\
\text { the Herirud } \\
\text { valley, east of } \\
\text { Herat. }\end{array}$ & Agriculturalists \\
\hline TAYMURI & $\begin{array}{l}\text { Assumed to } \\
\text { derive its name } \\
\text { from Emir } \\
\text { Taymur, who gave } \\
\text { the tribe as a } \\
\text { gift to one of } \\
\text { his generals. }\end{array}$ & $220-230$ & $\begin{array}{l}\text { South of Herat, } \\
\text { along the Afghan- } \\
\text { Iranian border, } \\
\text { near the namaksar } \\
\text { lake and in the } \\
\text { Dasht-e naumid } \\
\text { desert. }\end{array}$ & $\begin{array}{c}\text { Nomadic } \\
\text { transhumants }\end{array}$ \\
\hline FIRUZKUHI & $\begin{array}{l}\text { Moved to their } \\
\text { current location } \\
\text { by Emir Taymur } \\
\text { in the } 15^{\text {th }} \\
\text { century. Name is } \\
\text { derived ether } \\
\text { from the } \\
\text { fortress of } \\
\text { Firuzkuh in } \\
\text { Iranian } \\
\text { Mazanderan or } \\
\text { Firuzkuh the } \\
\text { capital of the } \\
\text { Ghurids. }\end{array}$ & $120-130$ & $\begin{array}{l}\text { District Dawlatyar } \\
\text { in the eastern } \\
\text { part of Herat } \\
\text { province between } \\
\text { the Herirud and } \\
\text { Murghab rivers and } \\
\text { in the vicinity of } \\
\text { Chahcharan. }\end{array}$ & $\begin{array}{l}\text { Semi-nomadic } \\
\text { transhumants }\end{array}$ \\
\hline
\end{tabular}

Based on Moshkalo, 1997, pp.200-201.

\subsubsection{BALUCH.}

Etymology unknown. These predominantly nomadic tribal people are scattered in Pakistan (approximately 4,000,000) (predominantly in province Baluchistan), the 
neighbouring areas of Afghanistan (approximately 350,000-400,000) and Iran $(1,500,000)$ as well as in the Gulf $(200,000)$ and Turkmenistan $(38,000-40,000)$. In Afghanistan the Baluch reside in the provinces of Kandahar, Hilmand, Nimruz, Farah and Herat. The Baluch are mainly Hanafi Sunnis with a small minority of the Dhikris in Pakistan.

The Baluchi language belongs to the North-western group of Iranian languages and is divided into western and eastern groups of dialects, which being separated by the Brahui belt are not always mutually understandable. Written literature emerged only in the $20^{\text {th }}$ century, however oral traditions are abundant. (Frye, 1960, pp.1005-1006; Moshkalo, 1999, pp.28-30).

\subsubsection{THE PAMIRIS.}

The Pamiris also mistakenly known as mountain or Pamiri Tajiks reside in the basin of the Panj River in both Tajik and Afghan Badakhshan as well as in isolated pockets in the neighbouring areas of China and Pakistan. Their total number reaches approximately 200,000 people, with 60,000 to 80,000 of them living in Afghanistan. Except for Yazghulamis who are Sunnis ${ }^{64}$, they are all Ismaili Muslims (some of their Tajik neighbours are also Ismaili) and they were persecuted on religious grounds by both Afghan and Bukharian Sunni authorities when they in the late $19^{\text {th }}$ century upon securing a silent British and Russian agreement divided the previously united Pamiri areas of Badakhshan between themselves. Religious and social life of the Pamiris is dominated by hereditary Ismaili spiritual masters ( $\left.p^{3} r s\right)$, who are hold in the highest

\footnotetext{
${ }^{64}$ The Sunni Yaghnobis, whose language is also considered as belonging to the Pamiri group, live in isolation from their linguistic brethren and culturally do not belong to the Pamiri milieu. Nevertheless, they retain some cultural similarity with the Pamiris going back to preIslamic times.
} 
possible esteem. Until recently the $p^{3}$ rs were virtually independent and only in the 1990's the spiritual leader of all Ismailis Prince Aga Khan IV reaffirmed his position in the area. Having sided with the Kabul government in the 1980's, which they believed will help them to assert their position vis-à-vis Sunni dominance and policy of discrimination, the Ismaili Pamiris found themselves in a difficult situation after the mojkahed $n$ victory in 1992 . Fearing for their religious and cultural heritage many Ismaili communities in the Pamirs decided to hide their religious books in the caves; after hearing of the destruction of Ismaili library in Pol-e Khumri by the -T a lebłan the Pamiris took all their remaining books away. Currently the Pamiripopulated area is one of the poorest in Afghanistan, which survives mainly due to the assistance of the international Ismaili NGO Focus and UN humanitarian agencies. The Pamiris are engaged in agriculture and arboriculture with drug smuggling ${ }^{65}$ playing an important role in their economic life on both sides of the Afghan-Tajik border. Despite (or perhaps because of it) their isolation and economic destitute the Ismaili Pamiris maintain a liberal life-style, characterised by religious and gender tolerance as well as by a very high regard for education, both religious and secular.

In a strict linguistic sense the term "Pamiri languages" can be used only tentatively, since it is still unclear whether these languages are inter-related closely enough in order to constitute a single group. While all linguistic authorities agree that they belong to the East Iranian group, some Pamiri languages have more common traits with Pashto - the most numerous East Iranian language, rather than with each other. Only Shughni and Yazghulami display enough similarities allowing to trace their common origin to a not that distant past and put them into one category. At the same time, other Pamiri languages preserved a number of features setting them apart

${ }^{65}$ Recreational and medical consumption of raw opium has always been a characteristic trait of the Pamiri lifestyle. 
from more closely related Shughni and Yazghulami. Thus, it still remains unclear whether Pamiri languages originate from a single proto-Pamiri source or did they develop from separate branches of a more ancient group of Iranian languages, presumably Saka (Edel'man, 1989, p.330; Morgenstierne, 1938, vol.II, p.XVIII; Sokolova, 1967, pp.3-6, 21, 124-125). What unites the Pamiri languages on the extragenetic level is the preservation of a significant number of archaic features that can be traced back to the ancient Iranian languages and a uniform influence of Tajiki/Dari ${ }^{66}$ on all of them.

All Pamiri languages are unwritten with only oral literary tradition. However, in the 1930s there were attempts to introduce Shughni and Wakhi alphabets based on Latin letters; now this work is again under way in Tajikistan. The area of the Pamiri languages is constantly shrinking in favour of Tajiki and Dari.

Due to the superior number of its speakers the Shughni language occupies the dominant position among other Pamiri languages. Moreover, unlike other Pamiri languages, the Shughni language is spoken not just in one gorge, but in a few mountain valleys. However, there is still no supra-dialect form and Shughni poetry retains local dialect characteristics.

In the areas of close contacts between various ethno-linguistic groups many Pamiris are bilingual or even multilingual in the Pamiri languages. In the case of mixed ethnic marriages the family usually uses the language of the wife for. communication. If husband and wife speak mutually understandable languages the standard practice is that the woman speaks her own first language to her family and her husband and children address her in the language of the region of their domicile.

\footnotetext{
${ }^{66}$ There is little difference between the Tajiki and Dari dialects of both Afghan and Tajik Badakhshan, which are used as lingua franca by all Pamiris, however they differ considerably from the normative Dari and Tajiki.
} 
However, this situation may change if the family lives in the area of the Shughni language. In that case, all members of the family start to speak Shughni (Dodykhudoeva, 1997, p.87). In general there is a tendency to use Shughni as a second Pamiri lingua franca and to a certain degree impose it on non-Shughni speakers, who are sometimes looked down at as qishloqi (ruffians). Although these 
Chart 20. The group of the Pamiri languages.

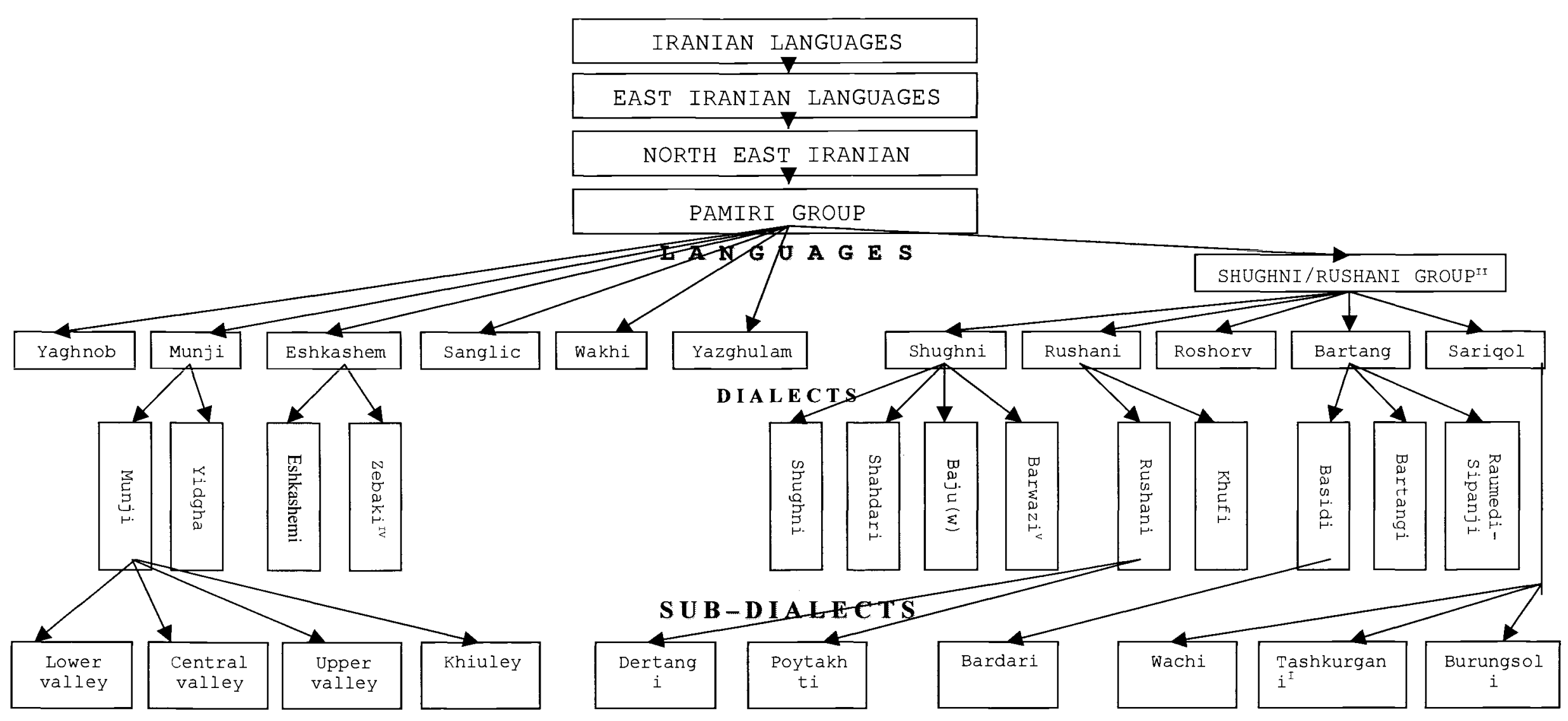

ENDNOTES FOR ChART 20.

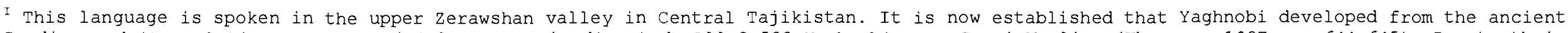

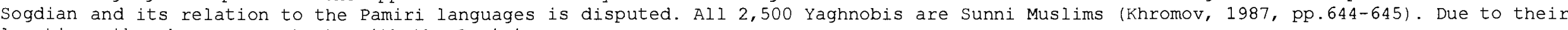
location, they have no contacts with the Pamiris.

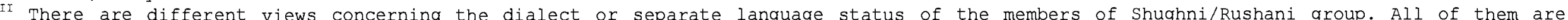

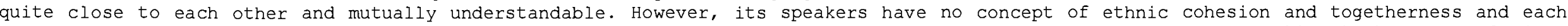

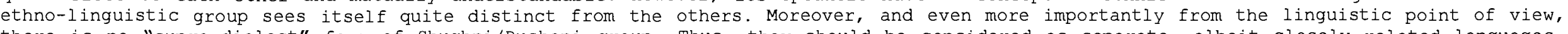

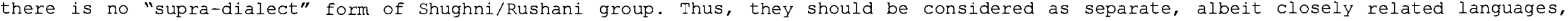
which originated from a single source in a not that distant past (Edel'man, 1987, p.236).

II Some linguists consider Roshorvi as a separate language, others as a dialect of Bartangi (Sokolova, 1967).

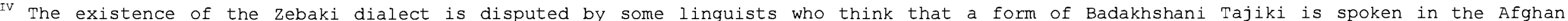
village of Zebak (Oranskii, 1988, p.330).

$\mathrm{v}$ Now extinct. 
tensions are rather low-scale, silent resistance of non-Shughni speakers to this attitude finds its expression in their preference of Tajiki in the case of mixed marriages.

Despite their linguistic differences, the Pamiris share a common cultural, social and religious background. Notwithstanding this extra-linguistic uniformity the Pamiris have little sense of regional unity and identify themselves only with their respective ethnic groups. Linguistic divisions do not always coincide with ethnic boundaries, thus there exist the following ethnic groups among the Pamiris that often transgress the linguistic differences

Chart 21. EThNIC COMPOSItion OF the PAMIRI peOples ACCORDING TO THE SELFIDENTIFICATION OF VARIOUS ETHNIC GROUPS*

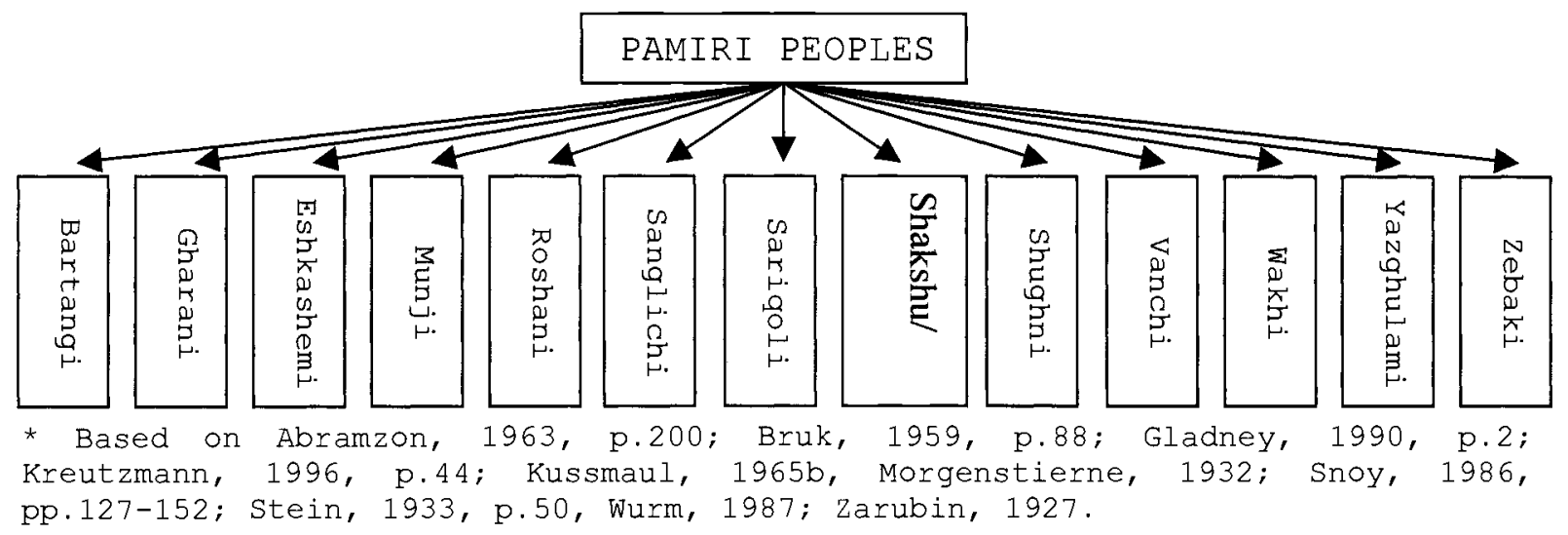

All Pamiri ethnic groups have their own ethnic names rendered in their native languages, which coincide with both Dari/Tajiki and Pamiri toponyms of the areas of their residence ${ }^{67}$. At the same time, when describing themselves to outsiders the Pamiris often call themselves Tajiks.

However, as it was mentioned above, linguistically, ethnically and culturally the Pamiris differ from the Tajiks and this distinction is made even more conspicuous

${ }^{67}$ With the exception of the Wakhis who call themselves "xik and their land $W u_{n} x$, while in Dari/Tajiki it is Wakh ${ }^{3}$ and Wakhran. 
by their use of the ethnonym "tcajek". The Pamiris refer only to themselves as Tajiks, while Tajiks proper are described by them as Persian-speakers p\&ars ${ }^{3}-$ $g \notin u^{68}$ (Malitskii, 1929, p.52) or $f \xi a r s^{3} z a b \xi a n$; similarly they call their own East Iranian languages Tajiki and the language of the Tajiks proper is known to them as Persian (Andreev, 1945, pp.45-70). At the same time, the Shughnis and Roshanis as well as the Tajiks of Darwaz" claim that they "became Tajiks not such a long time ago". The ethnographer who reported this statement saw it as a proof of a relatively recent conversion of these people to Islam (Maslovskii, 1901, p.19). However, the Ismailis of the Pamirs trace their spiritual genealogy back to the time of N\&a-ser-e Khosraw, and 900 years cannot be considered as a "not such a long time",70. Thus, this assertion must reflect something else.

Thus, alongside with minority groups in Fars, some Dards of Afghanistan and Turks of Central Asia, the Pamiris preserved some aspects of the original meaning of the word " $t$ kajek", viz. a distinct ethno-linguistic group that differs from the rest by its language(s) and way of life. It appears that the Islamic dimension of the term "tcajek" is now less important.

Among their Tajik and Uzbek neighbours living in the valleys and plains the Pamiris as well as the Yaghnobis are known by the derogatory appellation ghalchah ${ }^{7 l}$. The origin of this word is unknown; perhaps it can be compared with Sogdian $\gamma \delta$ (to steal) and Pashto ghal (thief) or alternatively with Sogdian $y r$ (mountain) (Frye, 1965,

\footnotetext{
${ }^{68}$ It is notable that the same distinction is applicable to the Sogdian description of the speakers of New Persian ( $t$ cjjeg) and the speakers of Middle Persian (płarsig) (Sundermann, 1993, p.171).

${ }^{69}$ It is not clear, whether these Darwazis were previously Ismailis or Sunnis. The majority of Darwaz Muslims are Sunnis, but there are also a few Ismaili villages in the area.

${ }^{70}$ The conversion of the Pamiris to Ismailism was completed only in the $14^{\text {th }}$ century by the Khorasani Ismaili missionaries. Still, it is quite a long time ago.

${ }^{71}$ That is "peasant" or "ruffian" in Persian and "squat", "stupid" in Tajiki and "slave" in old Yaghnobi. This term is unknown among the Pamiris themselves (Zarubin, 1925, p.60).
} 
p.997) and Pashto gař (mountain). It is a common trait for the Eastern Iranian $\check{r}$ to develop into the Western Iranian $l$, hence grachah/gařchah $\rightarrow$ galchah - people of the mountains. It seems that various derivations from this form were wide-spread in early medieval toponyms of the Eastern Iranian lands: thus, a mountain country in the upper Murghab was known as Garch or Garchistan and the $12^{\text {th }}$ century author Sam' \&an $\& u$ mentioned "the Gharchistan of Samarqand" in the upper Zerawshan valley. However, the ethnonym yarčak or yarčik cannot be found in any pre-Islamic source (Bartol'd, 1971, pp.62, 262).

\subsubsection{TURKIC PEOPLES.}

Although the majority of the people of Afghanistan are Iranians there are also considerable Turkic minorities that occupy their own distinct political and socioeconomic niches; moreover, on a number of occasions these minorities turned out to be a an important and specific factor shaping the course of Afghan history - the fact often overlooked by the students of Afghanistan.

\subsubsection{UZBEKS.}

Uzbeks are the most numerous and politically active Turkic group in Afghanistan. Their number is estimated as $1,000,000$, they live predominantly in Northern Afghanistan as sedentary farmers and transhumants. They speak Chagatay (central Turkic) dialects and refer to themselves by their old tribal names Haraki, Kamaki, Mangit, Ming, Shesh Qara and Taymus (Centlivres, 1976).

Prior to Emir ôAbd al-Ra-hman's conquest of Northern Afghanistan in the late $19^{\text {th }}$ century Uzbeks were the politically dominant ethnic group there associated with the Turkic principalities of the north, which were ruled in accordance 
with the decentralised Chingizid paradigm (Lee, 1996; McChesney, 1991; Noelle, 1997, pp.60-71). After the assertion of the Kabul authority in the north Uzbeks were usually considered as second-class citizens and some Pashtun (mainly Durrani) clans were resettled in the area in order to consolidate the government's grip on the area. In the early 1990's the Uzbeks attempted to renegotiate their political position by throwing their considerable military weight in favour of different factions or even occasionally dominating the political process. These developments found their organisational framework in the establishment of the Uzbek-dominated Islamic National Movement of Afghanistan (Jonbe,s-e Esl\&am³-ye Mell-ye Afghcanestcan) headed by General ôAbd al-Ra "s ${ }^{3} \mathrm{~d}$ Dłostom in 19931997 (for more details see Chapter Two).

\subsubsection{TURKMENS.}

Approximately 400,000 Turkmens are concentrated mainly in the north-western areas of Afghanistan bordering Turkmenistan. They are tribal people with the following major divisions found in Afghanistan: Tekke, Yomud, Tariq and Lakai in the Herat region; Tekke and Ersari in Aqcha; Saroq and Chakra in Andkhoy; Salor in Maymana and Maruchak; Ersari and Mawri in Dawlatabad. They speak the Oguz dialect. The Turkmens are predominantly semi-sedentary, semi-nomadic farmer-herdsmen. Many of them arrived to Afghanistan in the late 1920's following the defeat of the anticommunist Islamist basmachi movement in Soviet Central Asia (Dupree, 1985, p.498).

\subsubsection{KIRGHIZ.}

The Kirghiz can be found only in the easternmost parts of the Wakhan corridor. They number a few thousand, speak a Qipchaq dialect and are engaged in nomadic 
pastoralism tending sheep, goats and yaks. In 1979 members of one of the two Kirghiz tribal lineages left Afghanistan because of rivalry with the other tribal group and disagreement with the new regime in Kabul. After some peregrination they settled down in Turkey (for more details see Shahrani, 1979)

The Kirghiz of Afghan Wakhan fell under the Afghan control by an accident of history. Since both geopolitical rivals in the area, namely the Russian and British empires, were keen to avoid having a common border in 1891 Emir ôAbd al$\mathrm{Ra}-\mathrm{hm} \dot{\mathrm{an}}$ was forced to reluctantly accept the narrow Wakhan corridor as a part of his kingdom; in return he was paid an annual stipend of 100,000 Indian rupees.

In 1999 the government of Kirghizstan following its programme of indigenisation offered the Afghan Kirghiz to move to their homeland. Despite their enthusiastic response the President of the Islamic State of Afghanistan Rabb an $^{3}$ did not allow them to emigrate insisting that being Afghan citizens they must stay in Afghanistan.

\subsubsection{OTHER PEOPLES.}

\subsubsection{NURISTANIS.}

Nuristan (formerly Kafiristan) occupies the area lying roughly between latitude $35^{\circ}$ $36^{\circ}$ North and longitude $70^{\circ}-71^{\circ} 30^{\prime}$ East, bounded on the west by the Panjsher River valley; on the east by the mountain range separating the Kunar-Bashgal valley from Chitral (roughly the modern Afghan-Pakistani border); on the north by the mountains forming the watershed between the rivers of Nuristan draining southwards and those of Munjan and Badakhshan draining northwards to the Oxus; and on the south by the Kabul River valley. The southern fringe of Nuristan is populated by the Pashtuns, while Nuristanis occupy the more northerly region, comprising from west to east the 
basins of the ôAlishang and ôAlingar, of the Pech or Prasun and the Waigal, and of the Bashgal. Above these steep-sided valleys the Hindukush mountains rise almost to 6,000 metres. Prior to the 1992 administrative division of the country into 32 provinces Nuristan was divided between Afghan provinces of Laghman and Kunar, with Mirtalam in the lower ôAlingar valley as an important centre. Later on, Nuristan, which comprises six districts (woloswkal ${ }^{3}$ ) was granted a provincial status. However, it was not recognised by all Afghan governments.

The Kafiri languages native to Nuristan have much in common with the Dardic languages and are spoken in close geographical proximity to them, but their origin is not the same. The Kafiri languages represent an independent branch of the Aryan family of the Indo-European languages belonging neither to the Iranian nor to the Indo-Aryan group (Edel'man, 1996, pp.27-28). They are all unwritten languages, though in the late 1980's the Afghan Academy of Sciences attempted to devise alphabets for the Kafiri languages. Although the linguistic part of the programme was completed with the assistance of the Soviet linguists its practical implementation was stopped after the moj $\xi a h e d^{3} n$ victory in 1992.

Due to the continuing geographical isolation of Nuristan (there are no proper roads connecting it to the rest of the country) knowledge of major languages of Afghanistan remains limited, with Dari being more popular than Pashto ${ }^{72}$.

There is a possibility that the people of Nuristan formerly known as Kafirs were called so by their Muslim neighbours not only because they were "infidels", but also because of the influence of the district names within Kafiristan of Katwar and Kator

\footnotetext{
${ }^{72}$ One of the reasons for the poor knowledge of Pashto and its low status is a badly concealed hostility towards Pashtuns, who are still scorned as enemy-conquerors, and especially the dislike of Nuristanis' closest neighbours the Safi Pashtun tribesmen (Griunberg, 1980, pp.1819).
} 
and the ethno-linguistic designation Kati on the non-Kafiri speakers (Scarcia, 1965, pp.CVI-CVII).

The inaccessibility of this region had made it a refuge area for a very old group of Indo-European peoples, probably mixed with an even older substratum. They were occasionally disturbed by abortive Muslim military expeditions, but their

Chart 22. The group of the Kafiri languages.

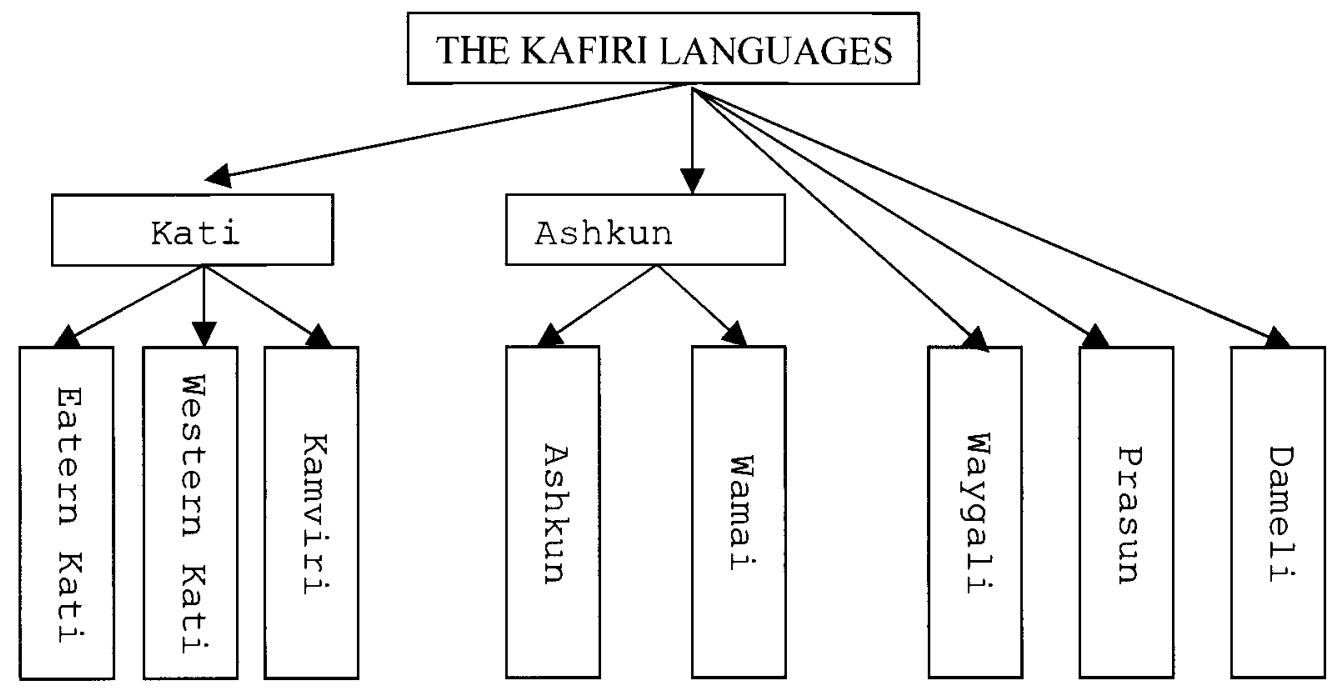

own frequent predatory raids against their neighbours notwithstanding, they remained in almost total isolation for centuries, thus retaining their archaic religious beliefs and social organisation.

According to the 1893 Kabul agreement between the Afghan Emir ôAbd al-Ra--hm $\xi a n$ and Sir Mortimer Durrand of the British Indian administration, Kafiristan was left outside the British Indian territory. Consequently, in 1895-1896 the Emir led a successful military expedition into the area bringing it under the Afghan control and implanting Sunni Islam among the pagan Kafirs. Subsequently, this territory was branded Nuristan (The Country of Light [of Islam]) and its people $j a d^{3} d^{3}$ (the newly converted) - however, this name did not stick to them. 
Nuristanis quickly integrated into the Afghan society (as far as integration of the people living in a far-away and hardly assessable periphery was possible) supplying a disproportionably high number of military officers, perhaps due to their reputation of ferocious fighters, superior in this respect even to the Pashtuns.

During the jehcad of the 1980's Nuristanis in general supported the moj $\operatorname{lahed}^{3} n$, however, their struggle against the Kabul government and Soviet forces was combined with demands for greater autonomy, which they in effect achieved by establishing a system of emirates answerable to no one, which survived even through the Taliban rule, when the area was left to its own devices by all parties involved in the Afghan Civil War.

The Nuristanis very quickly forgot their pre-Islamic beliefs (perhaps due to the lack of literary tradition) and by the 1960's when the serious field research started in Nuristan they were almost unaware of their ancestral religion.

The pagan religion of the Kafirs was a mixture of polytheism and animism with much emphasis on demons and evil spirits, who needed constant propitiation. The last pagan Kafirs, who immigrated to Chitral escaping a forced conversion to Islam, disappeared in the mid-1930's. (For more details on the Kafir religious beliefs see Jettmar, 1986).

The socio-political system that partly survived from pre-Islamic times is local, with no over-arching bodies, and clan-based. Clan affairs are managed by a council of senior clan headmen. Thirteen representatives are elected annually for the actual conduct of government. Social, political and in pre-Islamic times perhaps even religious status was determined by the ability to share wealth symbolised by the giving of feasts and potlatches and prowess in warfare when an elaborate system of ranks and privileges was bestowed upon successful killers. Apart from full clansmen 
there were poor freemen, mainly herdsmen, and a group of artisans as well as a small number of slaves, who were captives from warfare and were considered ritually impure. The tribal Nuristani society was and still is plagued by constant inter-tribal animosity and small-scale wars (Griunberg, 1980, pp.9-10, Jones, 1974).

The gender division of labour is characterised by reverse distribution of roles where women are engaged in agriculture and men look after cattle. Traditionally the status of women was low, with polygamy as the norm and exogamous marriages. However, women could improve their status by performing some rituals and distributing their wealth.

The distinction of "wearers of black" (seycah-pфu „s in Persian and tcor kcafer in Pashto) comprising five Kati clans and "wearers of white" ( $\operatorname{saf}^{3} d$ $p \nmid u_{1 /} s$ in Persian and $s p^{3} n k$ kafer in Pashto) comprising the Prasungeli, Waygali, Wamai and Ashkun is an old one, but its significance has not been established and it appears that nowadays it does not reflect any ethnic or tribal divisions. The ethnic composition of Nuristanis is much more complicated than the linguistic one. There is no common self-appellation and no sense of pan-Nuristani unity. Moreover, common languages do not contribute to the development of common identity among their speakers ${ }^{73}$.

Before the communist take-over in 1978, the population of Nuristan was estimated at between $34,000-90,000$ people $^{74}$. According to the data of the 1935 German expedition to the Hindukush at that time there were approximately 10,000

\footnotetext{
${ }^{73}$ Strictly speaking, the Kafir languages do not have indigenous designations and what is used as such is the combination of tribal names with the word "language". Thus, the Western Kati language is Kati vri / Kato vri - the language of the Katis (Griunberg, 1980, pp.22-23). According to $\mathrm{W}$. Ivanow, his native informant, a Kamviri-speaker interviewed in Bombay, was not even aware of the possibility to identify his language in this way and referred to it as Bashgali (Ivanow, 1932 p.149), thus using the Chitrali (Khowar S.A.) word describing the whole Nuristan (Robertson, 1896, p.8).

${ }^{74}$ There was never a proper census in Afghanistan.
} 
Eastern Kati, 10,000 Western Kati, 2,000 Prasuns, 6,000 Ashkuns, 1,000 Wamai and 5,000 Waygali (Deutsche im Hindukusch, 1937, p.75). No reliable later data is available.

Kafiristan/Nuristan always attracted researches specialising in various fields, hence the abundance of literature on this region, which is impossible to list here. For more bibliographical details see relevant sections in many bibliographies of Afghanistan, of which the most comprehensive, as far as Nuristan is concerned, are the following: Bucherer-Dietschi, 1979 - ; Jones, 1966; Jones, 1969; Jones, 1992; Kukhtina, 1965.

\subsubsection{THE DARDS.}

In Afghanistan the Dards are often referred to as Kלohest $\operatorname{con}^{3}$. They number approximately 60,000 people residing on the southern fringe of Nuristan and comprising Pashai, Gawar-bati, Sawaji, Dagani and Kuwar ethno-linguistic groups. Dards have no common self-appellation, with every ethnic group having a different name, usually derived from the areas inhabited by them. Consequently, there is no sense of political unity. Some of them, predominantly the Pashais, are Ismaili. Their social organisation has not been properly studied but it appears that they retain tribal system with elements of self-government subordinate to the Pashtun tribal rule ${ }^{75}$.

The Dardic languages are an offshoot of the Indo-Aryan languages of the postVedic period. This denomination can be derived from the Old Indic darád-; cf. dārada-, darada- designating the people of northern India and modern dard, dārd, being the self-appellation of the speakers of Gurezi, one of Shina dialects (Edel'man, 1996, p.27).

\footnotetext{
${ }^{75}$ For more details see Wutt, 1981 , which is the only available monograph on this subject.
} 
Only Kashmiri has an old literary tradition, some other Dardic languages of Pakistan acquired alphabets only recently while it is not the case in Afghanistan. For these reasons, Dari was the language of administration as well as religious and secular literature. However, the knowledge of this language and especially literacy in Dari was confined to the narrow circle of educated elite.

\subsubsection{BRAHUI.}

Brahui are the only Dravids of Afghanistan speaking their own distinctive language, however many of them also know Pashto or Baluchi. They reside in southwest Afghanistan and number approximately 10,000 being mainly tenant farmers or hired herders for Pashtun or Baluch notables. Their principal groups include Aydozay, Lawarzay, Yaghizay, Zirkandi and Mahmasani, though they like to be considered as a brunch of the Baluch - the claim not often reciprocated by the Baluch proper.

\subsubsection{MONGOLS.}

The Mongols of Afghanistan speak Dari, however the Mongolian substratum is clearly visible. There are also very small groups of Pashto-speaking Mongols in the South. There are several thousand Mongols scattered mainly throughout central and northern Afghanistan as highland agriculturalists. They were originally concentrated in Ghor province but approximately in the 1850 's they dispersed from there. It is quite possible that they are the descendants of Mongol troops that invaded Afghanistan in the $13^{\text {th }}$ century.

\subsubsection{ARABS.}


There are very few Afghan Arabs who still retain Arabic as their domestic language (four known villages west of Mazar-e Sharif with 50-100 households in each of them). These Arabs are unrelated to many Dari or Pashto-speaking groups claiming Arab descend (Kieffer, 1981, pp.178-196) and forming small semi-nomadic and semisedentary communities scattered all over the country but predominantly concentrated in the North where they resemble the Arabs of Central Asia. Many of them claim sayyed descend, which is rarely recognised outside their communities. Nevertheless, their Dari is often heavily Arabized.

\subsubsection{JEWS.}

Jewish presence in Afghanistan can be traced back to pre-Islamic times, though the exact number and position of the Jews is obscure (Gnoli, 1962, pp.311-312).

Prior to the 1980's there were several hundred Afghan Jews who were quite similar to Central Asian or Bukharan Jews. They resided in Kabul, Kandahar and Herat working as merchants and moneylenders. All of them spoke either Dari or Pashto, with Hebrew being only their sacred language. After the creation of Israel they gradually started to emigrate there.

During World War II Afghanistan was the only country that offered asylum to all European Jews without any discrimination and some of them found a safe haven there. After the war all these Jewish refugees left Afghanistan. Those Afghans who are aware of this fact take justifiable pride in their historical record.

In the 1980's all remaining Afghan Jews left for Israel. According to the hearsay, currently there are only two Jews left in Kabul and they are not on speaking terms with each other. One of them known as Isaac Levi was constantly sentenced by the - Tkalebcan for short spells in jail for sorcery. Thus he might be the last 
representative of a long-standing northern Afghan and Central Asian tradition, which invested Jews with special magical power.

\subsubsection{SIKHS AND HINDUS.}

Prior to 1992 there were approximately 20,000 Hindus and 10,000 Sikhs in Afghanistan. They resided in urban centres where they worked as merchants and moneylenders. Apart from either Dari or Pashto they also retained their Indian languages, mainly Hindi, Panjabi or Lahnda. After the moj cahed $^{3} n$ victory many of them tried to immigrate to India fearing the Islamization of public life in Afghanistan. Especially under the $-T \xi a$ leb an many of them found themselves in a precarious position being ordered in April 2001 to wear distinctive yellow marks on their cloths "for their own protection in order to distinguish them from Muslims" as the Tcalebcan claimed. Fortunately, this edict was not implemented.

\subsection{PECULIARITIES OF AFGHAN ISLAM: SUNNITES, SHIITES, ISMAILIS AND SUFIS ${ }^{76}$.}

Islam was first brought into the territory of modern Afghanistan by Arab troops, which occupied Herat in 652 A.D.. Since that time Islam gradually progressed throughout the country, affecting mainly urban population. The massive conversion of Afghans started only under Ma--hm cud of Ghazni, who established his capital in the Pashtun lands and attracted tribesmen by his successful expeditions. However, the bulk of Afghan homelands remained unsubdued and subject to no organized

\footnotetext{
${ }^{76}$ Political Islam of the $20^{\text {th }}$ and $21^{\text {st }}$ centuries is dealt with in the relevant sections of Chapter Two.
} 
government, either foreign or domestic; even in the $13^{\text {th }}$ century Muslim ôolam caé issued fatwcas against pagan Afghans (Samarqand ${ }^{3}, 1829$, p.66) and compared their belief with the religion of the Mongols (Qa zw $\left.{ }^{3} n^{3}, 1911-14, p .644\right)$. As late as in the $16^{\text {th }}$ century B bor wrote about "the Kafir robbers" near Kabul and infidels' settlements in Nangrahar. (B bor, 1969, pp.205, 342), but he did not specify whether these "Kafirs" were Pashtuns or not. It is noteworthy that according to the local tradition some Afghan tribes remained non-Muslim even until the beginning of the $19^{\text {th }}$ century (Kohat Gazetteer, 1884, p.69). However, the Pashtuns have no memory of a pre-Islamic past ${ }^{77}$ and there is nothing in recorded history, which suggests that they were forcibly converted to Islam.

Formal conversion to Islam differs substantially from genuine Islamization, i.e. the adoption of Islamic symbolism and practice in everyday life. In the premodern periods normative Islam is generally associated with urban rather than rural culture. Since Afghanistan was, and still is, predominantly rural and tribal, nonIslamic practices not only survived there, especially among the Pashtuns but also dominated their life for a long period of time thus making the cultural contradiction between normative urban Islam and Afghan tribalism a major theme of Afghan history. Many Afghan sources mention numerous clashes between tribal and religious leaders, between the tribal code of honour and the "sar ${ }^{3}$ ôt. This conflict did not have only a cultural character. Matters of social status and political dominance were always at stake. A Pashtun proverb "There are things in Khost [an area in the country of the Pashtuns] that are not in the Koran and there are things in the Koran that are not in Khost" (Janata and Hassas, 1975, p.83) acknowledges the apparent contradiction

\footnotetext{
${ }^{77}$ According to their own oral tradition they were never infidels but have always been monotheists, viz. Muslims. This belief is enshrined even in the Pashtuns' tribal genealogy. This problem is discussed in the section "Pashtuns".
} 
between tribal customs and the rules of $\operatorname{sar}^{3}$ ôt. Medieval ôolamłaé were well aware of the Pashtuns' attitude towards Islam and their knowledge of the religion, which they found unacceptable. Thus the $16^{\text {th }}-17^{\text {th }}$ century "orthodox" Islamic scholar $£ A k h$ cund $\operatorname{Darw}^{3} \mathrm{zah}$ lamented that Khattak women were ignorant even of the outward forms of religion and did not know how to pray properly (Darw ${ }^{3}$ zah, 1892, pp.74-75).

Nominal inclusion of the Pashtun tribes into the sphere of the Great Mughal influence in the $16^{\text {th }}$ century facilitated the process of Islamization defined in terms of a limited acceptance of normative urban Sunni Islam, but not at the expense of the tribal ethos. However, the political and social transformation of the Afghan parts of the Great Mughal Empire made an impact on the forms of expression of indigenous Islam.

In a competitive Pashtun society Islam also became a vehicle of political ideology. Relations between ethnic, tribal and social groups, particularly where they involve competition for limited resources are often expressed in terms of religious superiority, either in claims of religiosity or piety. Thus among the Durranis of Afghanistan these claims determine the character of religious belief and behaviour; while successful tribesmen subscribe to meticulous observation of Islamic ritual the underprivileged ones pursue ecstatic experiences associated with Sufism, shrines and possession by spirit (Tapper, 1984, pp.262-263). Besides, non-Pashtun client groups and junior Pashtun tribal lineages over-emphasise Islamic observance, as Ahmed writes, in order to counterbalance the elitism of the senior lineages. Among these senior lineages Islamic knowledge is transmitted not through the memory of the teaching of great scholars or Sufi masters or their shrines but through everyday tribal lore and common descent memory (Ahmed, 1984, p.319). 
Although the territory of modern Afghanistan is the birthplace of a number of Sufi brotherhoods (Azami, Chishti) little is known about Sufi activities among the Pashtuns, while they flourished along the traditional lines of Sufi brotherhoods among mainly urban non-Pashtuns.

In the 19th century the Qadiriyya became one of the most powerful Sufi brotherhoods among the eastern Pashtun tribes (Olesen, 1995, p.46), thus wrestling the dominance away from the previously all-powerful Naqshbandiyya.

The travelling Naqshbandi $m \varphi \circ r^{3} d s$ and $m c o r_{1}$ seds maintained close ties between the Naqshbandi centres in Central Asia, Afghanistan and India. The Naqshbandi position in the Pashtun lands was strengthened by the efforts of the famous religious reformer ...Saykh A-hmad Serhend ${ }^{3}$ (1564-1624) and his disciples from the tribal area (Rizvi, 1978-1983, vol.II, pp.180-181, 232-233). However prominent Naqshbandi masters independent of the influence of A-hmad Serhend ${ }^{3}$ were also active among the Pashtun tribesmen.

These Sufi brotherhoods which had been most widespread among the Pashtuns are in general characterised by adherence to "orthodoxy" and emphasis on the observance of the "sar ${ }^{3}$ ôt and spiritual sobriety.

Although the bulk of the Pashtuns are Sunnites there are some Shiite clans as well, i.e. that of the Orakzay and Bangash tribes (Ridgway, 1910, p.159; Rose, 1914, vol.III, p.177). However, according to some British Indian sources these people converted to Shiism only in the $18^{\text {th }}$ and $19^{\text {th }}$ century (Kohat Gazetteer, 1884, p.69; White King, 1984, p.151).

It appears that there are no Pashtun tribal groups openly professing Ismailism. However, an Ismaili presence in the regions close to the Pashtun lands can be traced at least since the Mongol invasion of Persia when many of the Kuhistani Nez $\operatorname{car}^{3} \mathrm{~s}$ 
who survived the Mongol massacres migrated to Afghanistan, Sind and Punjab. In the course of time the hereditary Ismaili $p^{3} r S$ in the remote areas like Afghanistan became practically independent from the authority of the emcam who, however, through a number of emissaries, always tried to assert his influence in this region (Daftary, 1990, pp.444-445, 468-470). D. Balland, relying on the British Indian tradition, thinks that the Ismaili presence in the region can be traced to the $10^{\text {th }}$ century, the time of a short-lived Ismaili domain in Multan and Kharijite activities in Gardiz. Balland goes as far as to suggest that the Bangash tribe, which occupies a separate position in the Pashtun genealogy, was formed as a result of the Ismaili missionary activity. He also asserts that the Orakzay and Turi tribes were under strong Ismaili influence (Balland, 1995, pp.357-367). In this respect Raverty's remark that the Bangashs considered Aga Khan I as their head is noteworthy (Raverty, 1888, p.389).

Anthropological literature dealing with the Muslim world, and especially Islamic tribes, paid much attention to the multi-functional position of the "holy man". The best-researched function of Sufi guides and mey $\operatorname{cans}^{78}$ is their ability to act as mediators in the factional, often kinship-based, conflicts of tribesmen, which is a

\footnotetext{
${ }^{78}$ In the Pashtun society mey ${ }^{2}$ ans are believed to be the descendants of scholars of ancient times. Some of them are designated sayyeds. Sociologically there is no distinction between the alleged descendants of the prophet Mo-hammad and offsprings of the famous oolam caé or Sufis, although sayyeds are held in higher esteem. Moreover, influential meycans are often called sayyeds disregarding their genealogy. The position of the sayyeds is different in the usually small tribes of dubious origin which claim descent from a sayyed who married an Afghan woman (Muhammad Hayat Khan, 1981, p.281). In these tribes the sayyed clans are fully integrated into the tribal structure and accept Pashtun women as brides. (Arlinghaus, 1993, p.12). However, according to Barth it is also the case with the Yusufzay tribe where the "holy men" marry Pashtun women. In general it is considered socially acceptable to marry a woman of a lower status. What is impossible is to give a girl of a high status to the man of a lower status.

Among Pashtun tribes the meycans occupy the same position as ôlam caé do $^{2}$ among non-tribal Muslims. Like all members of the ô lam $\xi a e ́$ class some meycans can be not only jurists but Sufi masters as well.
} 
universal characteristic of the "holy men" in many different societies ranging from Moroccan Berbers to Central Asian Turkmens. "The holy men" are not included in tribal lineages. Therefore they are in a favoured position to arbitrate conflicts since they do not share obligations of collective tribal responsibility. The "holy men's" shrines are often located in areas of potential conflict, e.g. market places and tribal boundaries. This location allows the "holy men" associated with the shrines to serve as a buffer between hostile tribal groups. For instance the Mohmand mey cans live in separate villages and hamlets situated at the boundary where two or more tribal segments meet. In Swat in line with this principle of neutrality houses of the Yusufzay $m e y \sim n s$ are inviolable; they often serve as a place of refuge for persecuted fugitives. In return for these services as political mediators the Yusufzay tribal segments occasionally grant prominent meycans permanent rights to land. Such plots (s $\zeta$ er $\div y$, not siri as Barth suggests) are then excluded from periodical re-allotment (wלe"s). Since meycans are excluded from re-allotment and thus do not occupy the daftar land, which is subject to whe" $s$, they do not enjoy full "tribal citizenship" and thus cannot speak at the tribal assembly (jergah). Although meycans do not posses full and equal rights their land ownership entitles them to independent status in tribal affairs. Besides, the meycan acts as a patron of the clients or dependents residing on his land who are thus also excluded from tribal structures. Unlike the property of the Pashtun tribesmen the land of the meycans is subject to the inheritance laws of the $-\operatorname{Hana}^{3}$ madhhab with an alteration that it can be held only by males (Barth, 1965, pp.92-103). Unlike their Yusufzay colleagues the Mohmand meycans do not keep clients (hamscayah) or dependent artisans (qasabdcar). The relatively respected social position of the Mohmand mey cans is 
largely due to their control over the only market place in the Mohmand area (Ahmed, 1984, p.322, 324).

The main religio-political role of the "holy men" is to reassert the unity and integrity of Islam challenged by tribal factionalism often combined with the threat of non-Muslim outsiders. The history of the Muslim World provides plenty of examples of the "holy men" leading various revivalist movements in defence of the values of Islam, e.g. the Sanusiyya of Cyrenaica and the Qadiriyya of Algeria, the Naqshbandi shaykhs in the North Caucasus who led the tribal rebellion against the Russian authorities as well as the mojcahed ${ }^{3} n$ of - $\operatorname{tar}^{3} q a t-e$ mo-hammadeyya, who united the Pashtun tribesmen against the Sikhs and the British. All these religious figures took the mantle of political leaders when the fissile social order proved itself ineffective.

This kind of political unification can be conditionally called "supra-tribal" since the tribesmen are united by charismatic religious leaders who appeal primarily to their religious feelings at the expense of their tribal identities ${ }^{79}$ As has been mentioned above, these religious leaders turned politicians, whether ô colamcaé or Sufi $p^{3} r s$, are not an integral part of the segmentary tribal structures based on kinship. They enjoy the status of alien "guests of honour" living in a tribal environment. Before they were included into the state structures as a result of a partial modernisation in the 20 th century they often tried to challenge tribal authority and

\footnotetext{
${ }^{79}$ When tribes act as the agents of political consolidation, conquest and even establishment of organised non-tribal rule they confine their political activities exclusively to their fellow tribesmen and keep other tribes at arms length. This was the case with the Khattak principality in the Khyber in the $17^{\text {th }}$ century and the Ghilzay conquest of Iran in the $18^{\text {th }}$ century.

When the "supra-tribal" model is applied the message of unification is meant to be spread as wide as possible and membership in the political coalition is offered to everyone, disregarding his tribal or even ethnic origin.
} 
create independent political bodies of their own supporters. In Pashto this process is called gond-b $a^{3} z^{3}$ (party-building). Fredrik Barth provides an account of the following of the religious leaders based on his fieldwork among the Yusufzays of Swat in the 1950 's. The followers of a "holy man" are recruited by a series of contract-like relations of the guide with individual devotees. By establishing a centre for the instruction of his followers the "holy man" welds his devotees into a coordinated group. Although the following of a "holy man" does not exclude membership in the men's house usually people choose between these two kinds of groups. Since members of all occupational classes (Barth calls them castes) may join the "holy man", the following of the religious guide provides a possibility of upward social mobility. The devotees of a recognised "holy man" acquire the rank of "saykh or mor ${ }^{3} d$ which entails certain social reverence irrespective of their previous status. Upon the attainment of some degrees of success the "saykh/mor ${ }^{3} d$ becomes known as $p^{3} r$. A $p^{3} r$ has in a sense changed his "caste"; his offspring are classed as the descendants of a "holy man". The special position and authority of "holy men" derives from three main sources: the custodianship of the graves of their holy ancestors which serve as shrines ${ }^{80}$ their traditional role as privileged mediator ${ }^{81}$ and adviser to people; their claim to spiritual leadership due to legal and mystical knowledge as well as moral dedication (Barth, 1965, pp.56-63, 92-103).

${ }^{80}$ However, there are many people of recognised holy descent who have no ancestral shrine.

81 This role is signified by their wearing a white turban, which makes the "holy men" inviolable in feud and permits them to cross from one warring camp to the other. However, this privilege is often abused and the "holy men" sometimes take arms. 
It appears that one kind of "holy men", namely the Sufi guides, enjoys an ambivalent position among the Pashtuns. They attract disciples from mainly poor background while men with claims to secular power, or to any degree of religious piety and learning never take an active part in Sufi ceremonies; however, they do not discourage others from doing so. (Tapper, 1984, pp.261-263). The Sufi guide exercises his influence outside tribal organisation and established patterns of social behaviour. Because of this, in contrast to the mey cans and mullahs, sociologically they are not a part of the tribal system. On the contrary, by the nature of their activity they constantly challenge this system. This paradigm of the coexistence of the Sufi guides and tribesmen cannot be applied to all tribes. Thus Akbar S. Ahmed maintains that the Mohmands do not follow any Sufi brotherhood. They see Sufism not as an acceptable alternative or supplement to traditional normative Islam but as a surrogate for it (Ahmed, 1984, pp.318-319).

If left unchecked by secular tribal authorities these bonds between the guide and his individual followers have an undercurrent tendency to evolve into the $g \nmid$ ond-b $\mathrm{C}_{z^{3}}$ type relationships when the religious leaders assume authority over large groups of people, normally subject to another, regular system of authority on a tribal lineage basis. As it often happens in Pashtun tribal society, individual relationships resembling the organisation of a traditional Sufi brotherhood turn into a new kind of institution; usually identified as "maraboutic Sufism"

\footnotetext{
${ }^{82}$ With regard to the Afghan realities this term was introduced by Olivier Roy (Roy, 1985 , pp.56-58). In the case of "maraboutic Sufism" affiliation to the spiritual guide is based on the collective adherence of a clan or tribe to a $p^{3} r$ 's family. Roy maintains that maraboutic $p^{3}$ rs never belonged to an established Sufi brotherhood or had any scholarly qualification or formed close master-disciple relations with their followers. However, Asta Olesen while accepting Roy's general definition of "maraboutic Sufism" correctly points out the number of cases when "maraboutic" guides belonged to the well-known -tareqats and had individual disciples (Olesen, 1995, pp.49-50). Thus it seems that "maraboutic Sufism" is first
} 
Probably the first recorded example of this pattern is provided in the Bcabor-ncamah. Bלabor reports that some 30 or 40 years before his 1519 expedition against the Pashtun tribes a heretic dervish (mul-hed qalandar) named ...S \&ahb\&az "perverted a body of Yusufzay and another of Dilazak". B bor ordered the destruction of his tomb in the Maqam mountains (B 4 abor, 1969, p.377). Everyone considered a "heretic" could be labelled mul-hed; however, very often this derogatory appellation was reserved for Ismailis. There are many similar examples recorded in later history of the area.

Later supra-tribal activities were usually caused by foreign invasions undertaken by non-Muslim countries, such as the three Anglo-Afghan wars and the Soviet involvement in Afghanistan. Sufi masters and mullahs occupy a position, which authorises them to initiate and direct practical actions such as the holy war (jeh $a_{d}$ ) which must be sanctioned, and is usually initiated, by people with a religious background ${ }^{83}$. These people also led the rebellions against political leaders who intolerably abuse their authority. Thus the relationships between spiritual master or tribal mediator and his personal followers turn into that between the leader of the holy war and the warriors of Islam. The latter relationships are founded on the gondb $c a z^{3}$ basis.

of all characterised not by the low level of the master's scholarship or lack of his affiliation to a Sufi brotherhood but rather by mass collective adherence to the guide, as opposed to the traditional individual one. However, this pattern does not totally exclude individual $p^{3} r-$ mor ${ }^{3} d$ relations, although the number of a master's individual followers is usually very low. Nowadays, one can observe the same process going on within the so-called "parties" of Afghan moj cahed $^{3} n$.

${ }^{83}$ Many British Indian sources refer to "the fanatics of the frontier" who led tribal rebellions against the British rule. The names of these leaders, i.e. MCOll\&a, $-\mathrm{Hajj}^{3}, \mathrm{Faq}^{3} \mathrm{r}$, etc, indicate that they all were of religious background. 
Usually these religion-inspired movements based on the gond-bcaz principle do not last for long. The only exceptions are the principality of Swat founded in the $19^{\text {th }}$ century by a religious leader and for long time governed by his descendants, as well as the Dhekr ${ }^{3}$ sect of the Makran Baluchis. Neighbouring Baluchi and Pashtun societies are organised along the tribal lines. However, there are certain differences between them. While the principality of Swat serves as an example of the triumph of normative Islam over tribal politics ${ }^{84}$ among the followers of marginalized and persecuted sects, like that of the Dhekr ${ }^{3} s$ the "holy men" help to boost the sectarians' psychological self-esteem in settings where more secular avenues of status aggrandizements are closed (Pastner, 1984, pp.303, 307-308).

The main difference between the Mohmand (egalitarian tribe) and Yusufzay (hierarchical tribe) "holy men" is that the former do not provide leadership against outside aggression nor can they claim to perform miracles. Only in complex hierarchical societies, e.g. the Yusufzays under the rule of the $w \xi a l^{3}$ of Swat, can religious groups aspire to political power. In this respect the failure of such religious leaders as ...Caknawcar and $-\mathrm{Hajj}^{3}$ of Turangzay to unite the Mohmands against the British in 1915-1916 serves as a good example of the political weakness of the "holy men" in this type of tribal society. Similarly Sayyed A-hmad ...S $\&$ ah Baralw ${ }^{3}$ who ruled Peshawar in 1830 was soon deserted by his tribal followers who could not tolerate a continuing assumption of political power by a non-tribal leaderthe pattern repeated time and again in Afghan history.

\footnotetext{
${ }^{84}$ Activities of the modern Afghan mojahed ${ }^{3} n$ provide another example of the same pattern. Given the importance of the $g o n d-b \zeta a z^{3}$ principle at the time of general political crisis it: seems that the self-appellation of many mojahed $n$ organisations "-he $z b / a-h z \zeta a b "$ (party) may be a good example of a "Freudian slip".
} 
The position of "holy men" within the Pashtun social hierarchy is ambivalent. They are aware that they are of superior status to a member of any occupational group not fully integrated into tribal genealogical structure. At the same time it appears that they are of lower status than the Pashtuns who consider them as their clients ${ }^{85}$. In the Mohmand tribe they began to intermarry with the Pashtuns from junior lineages only in the 1960 's. Previously they were an entirely endogamous group.

Both mey kans and Pashtuns remain distinct social groups with distinct functions. While the Pashtuns see themselves as the guardians of tribal customs, the mey ans' $^{\prime}$ main function is to maintain Islamic symbolism in their host society.

Economically both the mullahs and the meycans are sustained by the payment of zak kat money to them. The Pashtuns refer to zakkat as ôo"sr (Ahmed, 1984, p.314). The local mosque is kept in repair by communal labour and the mosque's em am is paid in kind for his service. Although the mullahs usually do not own inherited land, they gain access to the endowed lands of their mosques by serving as emcams (Barth, 1965, pp.15,18). In return they lead the congregation in prayer, preach in the mosque and perform rites of passage. Thus, their role is institutional and functional. The em cams hold their hereditary positions for life. However, the congregation may reject an incompetent successor. The position of the em̧am is always occupied by low-ranking members of the ôlam̧aé group; it ranks too low for the descendants of the meycans. The mullah may be respected but rarely is he venerated. He acts within the village social organisation, and in practice with the khלan's implicit permission.

\footnotetext{
${ }^{85}$ The Pashtun saying about religious groups goes as follows: "They do not carry guns and exist to serve us" (Ahmed, 1980, p.160).
} 
Apart from having political functions, "holy men" also help to channel religious feelings of the tribesmen who feel alienated from the urban and sophisticated Islam of the ôlamcaé. By the power of their barakat they demonstrate the immediacy of God's existence.

Apart from the Sunni majority Afghanistan also has significant Imami Shiite and Ismaili minorities. The former is predominantly confined to the Hazara people and the Qizilbash of Kabul, Herat and Kandahar, while the latter is practised by the Pamiris of Badakhshan and Hazara around Pul-e Khomri. In principle Shiism is much more unified and hierarchical than Sunnism, with religious dignitaries enjoying respect almost unparalleled in the Sunni environment. The most respectable figures are the descendants of the Prophet (those who are scadcad) and those who built their reputation on Islamic learning or pilgrimage to the holy places. However, this religion-based hierarchisation of the Hazara society (Of which tribal aristocracy is also an important part) did not mean a greater degree of internal unity than seen in a more egalitarian Pashtun society.

Another significant Shiite community - the Qizilbash ${ }^{86}$ have only their faith in common with the Hazara. Unlike rural and usually poor Hazara the Qizilbash form well-to-do urban communities.

In general, the Shiites always remain doctrinally potentially opposed to the rule of the Sunni majority and their position of a persecuted minority led to the religious acceptance of dissimulation of faith (taqeyyah), the fact that often causes much anti-Shiite irredentism.

\footnotetext{
${ }^{86}$ They played an important role in the establishment of the Safavi monarchy in Iran and arrived to

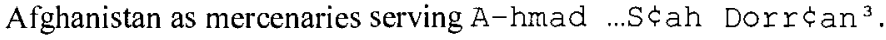


The Ismailis find themselves in an even more precarious position, notably because traditionally they do not have mosques and their prayer practice is visibly different. Their religious life is dominated by the hereditary spiritual leaders known locally as "kings" ("słah), claiming either sayyed or khwcajah descent who, as among the Imamis, form endogamous groups ${ }^{87}$. They are represented by their appointed "deputies" ( $\left.k h a l^{3} f a h\right)$ who are in charge of religious teaching, officiate in ritual and collect ô "sr (the tithe) payable to the "słahs and then supposed to be forwarded to the supreme Ismaili world leader (emcam) Aga Khan IV, who in the 1990 's carefully started to reassert his authority in the area.

\footnotetext{
${ }^{87}$ The leading family claiming but not always asserting authority over all Afghan Ismailis are the Qayh $\dot{c}^{3}{ }^{3}$ s of Pol-e Khumri.
} 


\section{BIBLIOGRAPHY}

1. Abramzon, 1963 - S. M. Abramzon, The Kirgiz of the Chinese People's Republic, in Central Asian Review, vol. $11(2), 1963$.

2. Ahmed, 1980 - Akbar S. Ahmed, Pukhtun Economy and Society: Traditional Structure and Economic Development in a Tribal Society, Routledge and Kegan Paul, London, 1980.

3. Ahmed, 1984 - Akbar S. Ahmed, Religious presence and symbolism in Pukhtun society, in Islam in Tribal Societies: From the Atlas to the Indus, Routledge and Kegan Paul, London, 1984.

4. Anderson, 1983 - Jon W. Anderson, Khan and Khel: Dialectics of Pakhtun Tribalism, in The Conflict of Tribe and State in Iran and Afghanistan, Croom Helm, London\& Canberra, St. Martin's Press, New York, 1983.

5. Anderson, 1984 - Jon W. Anderson, How Afghans define themselves in relation to Islam, in Revolutions and Rebellions in Afghanistan: Anthropological Perspectives, ed. by M. Nazif Shahrani and Robert L. Canfield, Institute of International Studies, Research Series No.57, University of California, Berkeley, 1984 .

6. Andreev, 1945 - M.S. Andreev, O tadzhikskom iazyke nastoiaschego vremeni, in Materialy po istorii tadzhikov i Tadzhikistana, Stalinabad, 1945.

7. Arlinghaus, 1993 - Joseph Arlinghaus, Varieties of Islamic expression in the Mughal province of Kabul in the 16th century, in Islam and Indian Regions, ed. by Anna Libera Dallapiccola, Stuttgart, Franz Steiner Verlag, 1993. 
8. Aslanov, 1966 - M.G. Aslanov, Afgansko-russkii slovar', Moscow, 1966.

9. Atai, 1983 - Atai M. Ibrakhim, Kratkii obzor etnograficheskoi struktury kakarov, in Pa,stco, vol.6, No.4, 1983.

10. Atayiee, 1983 - Atayiee M. Ibrahim, A look at the ethnographical structure of the Kakars, in Afghanistan, vol.36, Nos.3/4, 1983.

11. Bלabor, 1969 - -zcaher al-D ${ }^{3} \mathrm{n}$ Mo-hammad Bלabor Pład,skah Ghלaz ${ }^{3}$, Bלabor-ncamah, English translation by A.S. Beveridge, London 1969.

12. Balland, 1995 - Daniel Balland, Du Mythe l'Histoire: aux origines du Chi'isme chez les

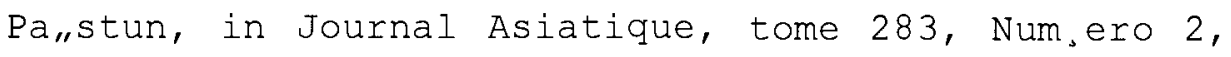
1995.

13. Bannu Gazetteer, 1883-4 - Gazetteer of the Bannu District 1883-1884, Lahore, 1884.

14. Barth, 1965 - Eredrik Barth, Political Leadership among Swat Pathans, The Athlone Press, New York, 1965.

15. Barth, 1981 - Eredrik Barth, Pathan Identity and its Maintenance, in Selected Essays of Fredrik Barth, vol. I, Routledge and Kegan Paul, London, 1981 .

16. Barth, 1987 - Eredrik Barth, Cultural Wellsprings of Resistance in Afghanistan, in Afghanistan: The Great Game Revisited, Freedom House, New York, 1987.

17. Bartol'd, 1963 - V.V. Bartol'd, Istorikogeograficheskii obzor Irana, in Sochineniia, vol. II, Nauka, Moscow, 1963.

18. Bartol'd, 1971, Istoriko-geograficheskii obzor Irana, in Sochineniia, vol.VII, Nauka, Moscow, 1971. 
19. Bellew, 1864 - H.W. Bellew, A General Report on the Yusufzais in Six Chapters with a Map, Lahore, Government Press, 1864.

20. de Benoist, 1981 - A. de Benoist, Nomadic Survey of Afghanistan by Province - July 1978, vols. 1-3, UN Reports, Kabul, 1981.

21. Bruk, 1959 - S.I. Bruk, The ethnography of Sinkiang and Tibet, in Central Asian Review, vol.7, 1959.

22. Bucherer-Dietschi, 1979 - - P. BuchererDietschi, Bibliotheca Afghanica, Liestal, Schweizerisches Afghanistan-Archiv, 1979 - continuing (continually updated bibliographic card index available by library subscription) .

23. Caroe, 1999 - Sir Olaf Caroe, The Pathans, 550 B.C. - A.D. 1957. With an Epilogue on Russia, Oxford University Press, Karachi 1999.

24. Centlivers, 1976 - P. Centlivers, Les Uzbeks du Qattaghan, Afghanistan Journal, vol.2, 1976.

25. Christensen, 1981 - Asger Christensen, Organization, Variation and Transformation in Pukhtun Society, in Ethnos, Nos.1-2, 1981.

26. Collin Davies, 1961 - C. Collin Davies, Afridi, in The Encyclopaedia of Islam, 2nd ed, vol. I, London-Leiden, 1961.

27. Cordovez and Harrison, 1995 - Diego Cordovez, Selig S. Harrison, Out of Afghanistan. The Inside Story of the Soviet Withdrawal, Oxford University Press, Oxford, New York, 1995.

28. Daftary, 1990 - Farhad Daftary, The Ismiaô ${ }^{3}{ }^{3}$ s; Their History and Doctrine, Cambridge University Press, Cambridge, 1990.

29. Darw ${ }^{3}$ zah, 1892 - EAkhkund Darw ${ }^{3} z a h$, Tadhkerah al-Abrcar wa al-A,srcar, Delhi, 1892. 
30. Davies, 1932 - C.C. Davies, The Problem of the North-West Frontier 1890-1908, London, 1932.

31. Dodykhudoeva, 1997 - L.R. Dodykhudoeva, Sotsiolingvisticheskaia situatsia Gornogo Badakhshana, in Malye Iazyki Evrazii, Moscow, 1997.

32. Dupree, 1980 - Louis Dupree, Afghanistan, Princeton, 1980.

33. Dupree, 1984 - Louis Dupree, Tribal warfare in Afghanistan and Pakistan: A reflection of the segmentary lineage system, in Islam in Tribal Societies: From the Atlas to the Indus, Routledge and Kegan Paul, London, 1984.

34. Edel'man, 1987 - D.I. Edel'man, Shugnanorushanskaia iazykovaia gruppa, in Osnovy iranskogo iazykoznaniia. Novoiranskie iazyki: vostochnaia gruppa, Moscow, Nauka, 1987.

35. Edel'man, 1989 - D.I. Edel'man, Eschio raz ob iransko-evropeiskikh izoglossakh, in Izvestiia AN SSSR, Otdelenie Literatury i iazyka, No.48, 1989.

36. Edel'man, 1996 - D.I. Edel'man, Dardestān. Languages, in Encyclopædia Iranica, vol. IV, Costa Mesa, 1996.

37. Efimov, 1997 - Khazara iazyk, in Iazyki mira. Iranskie iazyki, vol. I Iugo-zapadnye iranskie iazyki, ed. by V.S. Rastorgueva, V.V. Moshkalo, D.I. Edel'man, Indrik, Moscow, 1997.

38. Elphinstone, 1839 - Sir Mountstuart Elphinstone, An account of the Kingdom of Caubul and its Dependencies in Persia, Tartary and India, Vol. I, II. London 1839.

39. Ewans, Sir Martin Ewans, Afghanistan, A New History, Curzon Press, Richmon Surrey, 2001. 
40. FAO, 1965 - Survey of Land and Water Resources.

Afghanistan. General Report, United Nations Food and Agriculture Organisation, Rome, 1965.

41. Farhadi, 1975 - R. Farhadi, The spoken Dari of Afghanistan. A Grammar of Kaboli Dari (Persian), Compared to the Literary Language, mimeograph, Kabul, 1975.

42. Ferdinand, 1958 - K. Ferdinand, Afghanistan's Nomads, in Fra National Museets Asbejdsmark, 1958.

43. Ferdinand, 1962 - Klaus Ferdinand, Nomad Expansion and Commerce in Central Afghanistan, in Folk, No.4, 1962 .

44. Ferdinand, 1969 - K. Ferdinand, Nomadism in Afghanistan. With an Appendix on Milk Products, Akadémiai Kiadó, Budapest, 1969.

45. Frye, 1960 - Balu, cistan, in The Encyclopaedia of Islam, New Edition, vol.I, E.J. Brill, Leiden, Luzac \& Co, London, 1960.

46. Frye, 1965 - R.N. Frye, Ghal,ca, in The Encyclopaedia of Islam, New Edition, vol.II, Leiden London, 1965.

47. Giustozzi, 2000 - Antonio Giustozzi, War, Politics and Society in Afghanistan, 1978-1992., Hurst \& Co, London, 2000.

48. Gladney, 1990 - D.C. Gladney, The ethnogenesis of the Uighur, in Central Asian Survey, vol.9, 1990. 49. Glatzer, 1998 - Bernt Glatzer, Is Afghanistan on the brink of Ethnic and tribal disintegration, in Fundamentalism Reborn? Afghanistan and the Taliban, ed. by William Maley, C. Hurst \& Co, London, 1998. 50. Gnoli, 1962 - G. Gnoli, Jewish inscriptions in Afghanistan, in East and West, vol.13, No.4, 1962. 
51. Gommans, 1995 - Jos J.L. Gommans, The Rise of the Indo-Afghan Empire, c. 1710-1780, Leiden, New York, Köln, E.J. Brill, 1995.

52. Gordon, 1950 - L. Gordon, Sotsial'noekonomicheskii i obschestvennyi stroi afganskikh plemyon Indii vo vtoroi polovine XIX veka, in Voprosy Istorii, No.3, 1950.

53. Gordon, 1953 - L.R. Gordon, Agrarnye otnoshenia $\quad \mathrm{V}$ Severo-zapadnoi pogranichnoi provintsii Indii, Moscow, Izdatel'stvo AN SSSR, 1953.

54. Griunberg, 1980 - A.L. Griunberg, Iazyki Vostochnogo Gindukusha, Iazyk kati. Teksty, grammaticheskii ocherk, Moscow, Nauka, 1980.

55. Griunberg, Steblin-Kamenskii, 1989 - A.L.

Griunberg, I.M. Steblin-Kamenskii, Neskol'ko zamechanii po povodu otklika A.S. Davydova na stat'iu S.V. Cheshko, in Sovetskaia Etnografiia, No. 5,1989 .

56. Humlum, 1959 - La géographie de l'Afghanistan, ed. by Johannes Humlum, Copenhagen, 1959.

57. Ivanow, 1932 - W. Ivanow, A specimen from Bashgali from Kamdesh, Acta Orientalia, vol.10, 1932. 58. Janata and Hassas, 1975 - A. Janata und R. Hassas, Ghairatman - Der gute Pashtune. Exkurs über die Grundlage des Pashtunwali, in Afghanistan Journal, Jg.2, Heft 3, 1975.

59. Jettmar, 1986 - K. Jettmar, Religii Gindukusha, Moscow, Nauka, 1986; the Russian translation of the revised and enlarged version of $K$. Jettmar, Die Religionen des Hindukusch, mit Beiträgen von Schuyler Jones und Max Klimburg, Stuttgart - Berlin - Köln Mainz, Verlag W. Kohlhammer, 1975. 
60. Jones, 1966 - Schuyler Jones, An Annotated Bibliography of Nuristan (Kafiristan) and the Kalash Kafirs of Chitral. Part One, Hist. Filos. Medd. Dan. Vid. Selsk 41/3, Copenhagen, 1966 Jones,1969 - Schuyler Jones, A Bibliography of Nuristan (Kafiristan) and the Kalash kafirs of Chitral. Part Two. Selected Documents from the Secret and Political Records, 1885-1900, Hist. Filos. Medd. Dan. Vid. Selsk 43/q, Copenhagen, 1969. 62. Jones, 1974 - Schuyler Jones, Men of Influence in Nuristan. A Study of Social Control and Dispute Settlement in Waigal Valley, Afghanistan, Seminar press, London and New York, 1974.

63. Jones, 1992 - S. Jones, World Bibliographical Series, vol.135, Afghanistan, Oxford - Santa Barbara, Clio Press, 1992.

64. Kלakcakheyl, 1999 - Sayyed Bahcadur ...Sלah

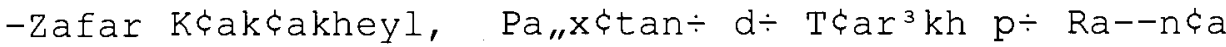
k, xke, Yלun ${ }^{3}$ werseŸt ${ }^{3}$ Buk £Ijans ${ }^{3}$, Peshawar, 1999. 65. Katkov, 1989 - I.E. Katkov, Sotsial'nye aspekty plemennoi struktury pushtunov, in Afganistan: Istoriia, Ekonomika, Kul'tura, Moscow, Nauka, 1989. 66. Kennedy, 1967 - T.F. Kennedy, Afghanistan Village, London, 1967.

67. Kh\&adem, 1952 - Qeycam al-D ${ }^{3} \mathrm{n}$ Khcadem, Pu, xtunwcalay, Kabul, 1952.

68. Khazanov, 1984 - A.M. Khazanov, Nomads and the outside World, Cambridge, Cambridge University Press, 1984 .

69. Khromov, 1987 - A.L. Khromov, Iagnobskii iazyk, in Osnovy iranskogo iazykoznaniia. Novoiranskie iazyki: vostochnaia gruppa, Moscow, Nauka, 1987. 70. Kieffer, 1981 - Ch. M. Kieffer, $\mathrm{L}^{\prime}$ arabe et les Arabophones de Bactriane, Situation ethnique et 
linguistique, in "Die Welt des Islams", vol. 20, 1981.

71. Kieffer, 1985 - Ch. M. Kieffer, Languages of Afghanistan in "Encyclopaedia Iranica", vol. 1, Routledge \& Kegan Paul, London, Boston and Henley, 1985 .

72. Kohat Gazetteer, 1884 - Gazetteer of the Kohat District, 1883-4, Calcutta, 1884.

73. Kreutzmann, 1996 - H. Kreutzmann, Ethnizität im

Entwicklungsprozeß. Die Wakhi in Hochasien, Berlin, 1986.

74. Kukhtina, 1965 - T. I. Kukhtina, Bibliografiia Afganistana: literatura na russkom iazyke, Moscow, Nauka, 1965.

75. Kussmaul, 1965b - F. Kussmaul, Seidlung und Gehöft bei den Tağiken in der Bergländern Afghanistans, in Anthropos, vol.60, 1965 .

76. Lancaster, 1981 - william Lancaster, The Rwala Bedouin, Cambridge University Press, Cambridge, 1981 .

77. Lee, 1996 - Jonathan L. Lee, The 'Ancient Supremacy', Bukhara, Afghanistan and the Battle for Balkh, 1731-1901, Leiden, J. Brill, 1996.

78. Lindholm, 1982 - Charles Lindholm, Generosity and Jealousy: The Swat Pukhtun of Northern Pakistan, Columbia University Press, New York, 1982.

79. Lindholm, 1993 - Charles Lindholm, Review of Akbar S. Ahmed, "Resistance and Control in Pakistan", in Man, vol.28, No.4, December 1993.

80. MacGregor, 1871 - Central Asia. Part II. A contribution towards the better knowledge of the topography, ethnology, resources and history of Afghanistan compiled (from political and military reference) by Lieut-Col. MacGregor, Assistant Quarter-Master-General, Calcutta, 1871 
81 . Majruh, 1969 - Sayd B. Majruh, Aktuelle Fragen des

Nomadismus in Afghanistan, in Nomadismus als Entwicklungsproblem, Bielefeld, 1969.

82 Maley, 1998

William Maley, The UN in Afghanistan: "Doing its best" or "Failure of a mission"?, in Fundamentalism Reborn? Afghanistan and the Taliban, ed. by William Maley, C. Hurst \& Co, London, 1998

83. Malitskii, 1929 - N.G. Malitskii, Uchebnoe posobie po geografii Tadzhikistana, Tashkent Samarkand, 1929.

84. Maslovskii, 1901 - S. Maslovskii, Gal'cha (Pervobytnoe naselenie Turkestana), in Russkii Antropologicheskii Zhurnal, vol.VI, No.2, 1901.

85. McChesney, 1991 - R.D. MCChesney, Waqf in Central Asia, Princeton, N.J., Princeton University Press, 1991.

86. Morgenstierne, 1932 - G. Morgenstierne, Report on a linguistic mission to North-Western India, Instituttet for Sammenlignende Kulturforskning, Serie C III-1, Oslo, 1932.

87. Morgenstierne, 1938 - G. Morgenstierne, IndoIranian Frontier Languages, vol.II Iranian Pamir Languages, Instituttet for Sammenlignende Kulturforskning, Serie B: Skrifter XXXV), Oslo, 1938. 88. Morgenstierne, 1961 - G. Morgenstierne, Afgh $\square$, The Encyclopaedia of Islam, 2nd ed, Vol.I, London Leiden, 1961 .

89. Moshkalo, 1997 - V.V. Moshkalo, Char-aymakov gruppa dialektov, in Iazyki mira. Iranskie iazyki, vol. I Iugo-zapadnye iranskie iazyki, ed. by V.S. Rastorgueva, V.V. Moshkalo, D.I. Edel'man, Indrik, Moscow, 1997.

90. Moshkalo, 1999 - V.V. Moshkalo, Beludzhskii iazyk in Iazyki mira. Iranskie iazyki, vol. I Iugo- 
zapadnye iranskie iazyki, ed. by V.S. Rastorgueva,

V.V. Moshkalo, D.I. Edel'man, Indrik, Moscow, 1999.

91. Mousavi, 1998 - S.A. Mousavi, The Hazaras of Afghanistan. An Historical, Cultural, Economic and Political Study, Curzon Press, Richmond, Surrey, 1998 .

92. Muhammad Hayat Khan, 1981 - Afghanistan and its Inhabitants, translated from "Hayat-i-Afghan" of Muhamad Hayat Khan, C.S. by Henry Priestley, Lahore, Sang-e-Meel Publications, 1981.

93. Neamet Ullah, 1829-1836 - History of the Afghans translated from the Persian of Neamet Ullah by Bernhard Dorn, vols.I-II, London, 1829-1836.

94. Noelle, 1997 - Christine Noelle, state and Tribe in Nineteenth-Century Afghanistan. The Reign of Amir Dost Muhammad Khan (1826-1863), Curzon Press, London, 1977.

95. O'Ballance, 1993 - Edgar O'Ballance, Afghan Wars 1839-1992: What Britain Gave Up and the soviet Union Lost, Brassey's, London, New York, 1993.

96. Olesen, 1995 - Asta Olesen, Islam and Politics in Afghanistan, Curzon Press, Richmond, Surrey, 1995.

97. Oranskii, 1988 - I.M. Oranskii, Vvedenie V iranskuiu filologiiu, Moscow, Nauka, 1988.

98. Pastner, 1984 - Stephen L. Pastner, Feuding with the spirit among the Zikri Baluch: The saint as champion of the despised, in Islam in Tribal Societies: From the Atlas to the Indus, Routledge and Kegan Paul, London, 1984.

99. Pelevin, 1993 - M.S. Pelevin, Religioznye vozzreniia afganskogo plemennogo vozhdia XVII veka, in Peterburgskoe Vostokovedenie, vol.IV, 1993. 
100. Peshawar Gazetteer, 1898 - Gazetteer of the Peshawar District, 1897-1898, Lahore, 1898.

101. Poliak, 1964 - A.A. Poliak, Ekonomicheskii stroi sovremennogo Afganistana, Moscow, 1964.

102. Poullada, 1962 - Leon Poullada, Problems of

Social Development in Afghanistan, in Journal of the

Royal Central Asian Society, vol.49, 1962

103. Poullada, 1973 - Leon B. Poullada, Reform and Rebellion in Afghanistan, 1919-1929: King Amanullah's Failure to Modernize a Tribal Society, Cornell University Press, Ithaca, N.Y., 1973.

104. Qazw ${ }^{3} \mathrm{n}^{3}$, 1911-1914 - The Thar ${ }^{3} \mathrm{kh}-i-G u z i d a h$ or

"Select History" of $-\mathrm{Ham}^{3} \mathrm{~d}$ Alliah Mustawf ${ }^{3}-\mathrm{i}-\mathrm{QazW}^{3} \mathrm{n}^{3}$ compiled in A.H. 730 (A.D. 1330), and now reproduced in fac-simile with English paraphrase from a manuscript dated A.H. 857 (A. D. 1453) with an introduction by E. G. Browne, Leiden-London, 191114.

105. Raverty, 1888 - Notes on Afghanistan and Part of Baluchistan, Geographical, Ethnographical, and Historical by Major H. G. Raverty, London, Eyre and Spottiswoode, 1888 .

106. Raverty, 1895 - The Waziri Afghans and Their Country, by Major H.G. Raverty, in The Imperial and Asiatic Quarterly Review and Oriental and Colonial Record, ser.2, vol.9, 1895.

107. Reisner, 1954 - I.M. Reisner, Razvitie feodalizma i obrazovanie gosudarstva u afgantsev, Moscow, Izdatel'stvo Akademii nauk SSSR, 1954.

108. Ridgway, 1910 - R.T.I. Ridgway, Pathans, Handbook for the Indian Army, Calcutta,

Superintendent Government Printing, 1910.

109. Robertson, 1896 - G.S. Robertson, The Kafirs of the Hindoo-Kush, London, 1896. 
110. Robinson, 1935 - J.A. Robinson, Notes on the Nomad Tribes of Eastern Afghanistan, New Delhi, 1935 .

111. Romodin, 1951[1] - V.A. Romodin, Sotsial'noekonomicheskii stroi iusufzaiskikh plemen $\mathrm{V}$ XIX v . (Sravnitel'no s drugimi afganskimi plemenami), (manuscript of the dissertation), Moscow, 1951.

112. Romodin, 1951[2] - V.A. Romodin, Sotsial'noekonomicheskii stroi iusufzaiskikh plemen $v$ pervoi polovine XIX $\mathrm{V}$. , in Ocherki po novoi istorii stran Srednego Vostoka, Moscow, 1951.

113. Romodin, 1964 - V.M. Masson, V.A. Romodin, Istoriia Afganistana, vol.II, Moscow, Nauka, 1964.

114. Romodin, 1980 - V.A. Romodin, Genealogicheskaia struktura osnovnykh grupp afganskikh (pashtunskikh) plemion $i$ ikh rasselenie v XVI-XVIIVv., in strany $i$ Narody Vostoka, vyp. 22, kniga 2, 1980.

115. Rose, 1914 - H.A. Rose, A Glossary of the Tribes and Castes of the Punjab and North-West Frontier Province, Lahore, 1914.

116. Roy, 1985 - Olivier Roy, L'Afghanistan: Islam et modernité politique, Éditions du Seuil, Paris, 1985 .

117. Rubin, 1995 - The Fragmentation of Afghanistan. State Formation and Collapse in the International System, Yale University Press, New Haven and London, 1995.

118. Rzehak, 1989 - Lutz Rzehak, Kodeks chesti pushtunov, in Afganistan: istoriia, ekonomika, kul'tura, Moscow, Nauka, 1989.

119. Rzehak and Griunberg, 1992 - L. Rzehak, A.L. Gryunberg, Nekotorye cherty traditsionnogo mirovozzreniia pushtunov, in Traditsionnoe 
mirovozzrenie u narodov Perednei Azii, Moscow, Nauka, 1992

120. Saidbaev, 1978 - T.S. Saidbaev, Islam i obschestvo, Moscow, Nauka, 1978.

121. Samarqand ${ }^{3}, 1829$ - extracts from Ma-tliaé alSaôdayn wa Majmaé al-Ba-hrayn by ôAbd al-Razzçaq Samarqand ${ }^{3}$, in The History of Afghans by Neamet Ullah Khan, English translation by B.Dorn, vol II, London, 1829.

122. Scarcia, 1965 - G. Scarcia, Sifat-ncama-yi

Darv $^{3}$ "s Mu-hammad Khłan-i ...Gלaz ${ }^{3}$. Cronaca di una crociata musulmana contro i Kafiri di Lagman nell'anno 1582, edito e tradotto da Gianroberto Scarcia, Serie orientale Roma XXXII, Rome, 1965

123. Sokolova, 1967 - V.S. Sokolova, Geneticheskie otnosheniia iazguliamskogo iazyka i shugnanskoi iazykovoi gruppy, Leningrad, Nauka, 1967.

124. Shahrani, 1979 - M. Shahrani, The Kirghiz and Wakhi of Afghanistan, Seattle, 1979.

125. Shroder, Jr., 1985 - J.F. Shroder, Jr., Afghanistan. Geography, in Encyclopaedia Iranica, vol. I, Routledge \& Kegan Paul, London, Boston and Henley, 1985.

126. Snoy, 1986 - P.Snoy, Die ethnischen Gruppen, in

Afghanistan. Ländermonographie, Schriftenreihe der Stiftung Bibliotheca Afghanica, vol.4, ed. by P. BuchererDietschi and C.Jentsch, Leistal, 1986.

127. Stein, 1933 - M.A. Stein, On Ancient CentralAsian Tracks. Brief Narrative of Three Expeditions in Innermost Asia and North-Western China, London, 1933. 128. Steul, 1981 - Willi Steul, Paschtunwali: Ein Ehrenkodex und seine Rechtliche Relevanz, Wiesbaden, 1981 . 
129. Sundermann, 1993 - W. Sundermann, An early attestation of the name of the Tajiks, in Medioiranica: Proceedings of the International Colloquium organized by the Katholike Universiteit Leuven from $21^{\text {st }}$ to $23^{\text {rd }}$ of May 1990, ed. by Wojciech Skalmowski and Alois van Tongerloo, Leuven, 1993.

130. Tapper, 1974 - Richard Tapper, Nomadism in modern Afghanistan: asset or anachronism?, in Afghanistan in the 1970s, Praeger Publishers, New York, London, 1974.

131. Tapper, 1983 - Richard Tapper, Introduction, in The Conflict of Tribe and State in Iran and Afghanistan, Croom Helm, London and Canberra, 1983.

132. Tapper, 1984 - Richard Tapper, Holier than thou: Islam in three tribal societies, in Islam in Tribal Societies: From the Atlas to the Indus, Routledge and Kegan Paul, London, 1984.

133. Tapper and Tapper, 1982 - Nancy Tapper and Richard Tapper, Marriage Preferences and Ethnic Relations among Durrani Pashtuns of Afghan Turkestan, in Folk, vol.24, 1982.

134. Tapper, N., 1991 - Nancy Tapper, Bartered Brides: Politics, Gender and Marriage in an Afghan Tribal Society, Cambridge University Press, Cambridge, 1991

135. Tupper, 1881 - C.L. Tupper, Punjab Customary Law, vols.I-III, Calcutta, 1881.

136. White King, 1984 - L. White King, The Orakzai Country and Clans, Lahore, 1984, being a reprint of I. White King, Monograph on the Orakzai Country and Clans, A Government Report, Lahore, 1900.

137. Wurm, 1987 - Atlas of China, 1987 - Language Atlas of China, Pacific Linguistics, Series C, No.102, ed. by S.A. Wurm et al., Hong Kong, 1987. 
138. Wutt, 1981 - K. Wutt, Pashai, Graz, 1981.

139. Wylly, 1912 - From the Black Mountain to Waziristan, being an account of the border countries and the more turbulent of the tribes controlled by the North-West Frontier Province, and of our military relations with them in the past, by Colonel H.C. Wylly, C.B., Macmillan \& Co., Limited, St Martin's Street, London 1912

140. Zaripov, 1989 - Sh. Zaripov, Kochevniki i polukochevniki Afganistana, in Afganistan: istoriia, ekonomika, kul'tura, Moscow, Nauka, 1989.

141. Zarubin, 1925 - I.I. Zarubin, Spisok narodnostei Turkestanskogo kraia, in Rossiiskaia Akademiia Nauk, Trudy Komissii po izucheniiu plemennogo sostava Rossii i sopredel'nykh stran, No.9, Leningrad, 1925.

142. Zarubin, 1927 -I.I. Zarubin, Spisok narodnostei SSSR. AN SSSR. Trudy Komissii po izucheniiu plemennogo sostava naseleniia SSSR i sopredel'nykh stran, Leningrad, 1927.

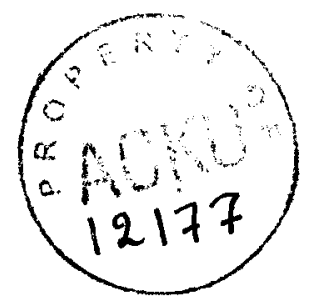


note:

The original material azu_acku_ds354_5_a53_2002: page 102 to 179: Missed 